\title{
PRODUÇÃO DE BACTERIOCINAS POR ENDÓFITOS DE CITROS E CARACTERIZAÇÃO DA ENDOFICINA L DE Curtobacterium flaccumfaciens ENDOFÍTICO
}

\author{
LUCIANA CURSINO Dos SANTOS
}

Tese apresentada à Escola Superior de Agricultura "Luiz de Queiroz", Universidade de São Paulo, para obtenção do título de Doutor em Agronomia, Área de Concentração: Genética e Melhoramento de Plantas.

PIRACICABA

Estado de São Paulo - Brasil

Junho - 2005 


\section{PRODUÇÃO DE BACTERIOCINAS POR ENDÓFITOS DE CITROS E CARACTERIZAÇÃO DA ENDOFICINA L DE Curtobacterium flaccumfaciens ENDOFÍTICO}

\section{LUCIANA CURSINO Dos SANTOS}

Bacharel em Ciências Biológicas

Orientador: Prof. Dr. JOÃo LÚcIO DE AZEVEDO

Tese apresentada à Escola Superior de Agricultura "Luiz de Queiroz", Universidade de São Paulo, para obtenção do título de Doutor em Agronomia, Área de Concentração: Genética e Melhoramento de Plantas.

PIRACICABA

Estado de São Paulo - Brasil

Junho - 2005 
Dados Internacionais de Catalogação na Publicação (CIP) DIVISÃO DE BIBLIOTECA E DOCUMENTAÇÃO - ESALQ/USP

Santos, Luciana Cursino dos

Produção de bacteriocinas por endófitos de citros e caracterização da endoficina L de Curtobacterium flaccumfaciens endofítico / Luciana Cursino dos Santos. - Piracicaba, 2005.

121 p. : il.

Tese (doutorado) - - Escola Superior de Agricultura Luiz de Queiroz, 2005. Bibliografia.

1. Bactéria endofítica 2. Bacteriocina 3. Clorose variegada dos citros 4. Genes 5. Ecologia microbiana 6. Proteína I. Título

CDD 634.31 
A minha família, por se estar comigo a cada longo passo e a cada tropeço...

Por se orgulharem de mim e me apoiarem incondicionalmente...

DEDICO

É loucura...

Desistir de todos os seus esforcos porque um deles fracassou...

Jogar fora todas as chances de acertar porque uma tentativa não deu certa...

Nunca cometeremos estas loucuras se lembrarmos que...

há sempre um outro caminho;

há sempre uma outra chance;

e uma nova força dentro de nós e em Deus...

O segredo é ser perseverante e procurar, mesmo quando tudo parecer perdido: Ser Feliz!

Aos meus amigos que longe de casa representaram a minha família. Àqueles que muitas vezes sorriram comigo, mas que nunca me abandonaram nos momentos difíceis. Sim ganhei amigos, mas perdi pessoas importantes: aos meus queridos avós maternos toda a minha saudade....

OFEREÇO 


\section{AGRADECIMENTOS}

A verdadeira noção de gratidão talvez seja complexa e indefinível. Assim, por vezes, não há como, apenas em palavras, descrevê-la. Quando deixei Beagá naquele dia chuvoso de Julho, com destino a Piracicaba, não fazia a menor noção daquilo que eu passaria ao longo destes quatro anos (de fato foram apenas três, um capítulo à parte será dedicado a Geneva). Na bagagem não trazia apenas roupas, calçados e etc. eu trazia a certeza de que as coisas seriam simples e corriqueiras. Contudo me surpreendia, dia após dia, com dificuldades grandes e complexas ou pequenas e simples. Talvez as dificuldades mais simples fossem àquelas que eu mais dificilmente compreendia. Foram realmente dias, meses, anos de adaptação. Enfim adaptada a um novo contexto a uma nova vida que em muitos aspectos era completamente diferente de tudo que eu já havia vivido. Evidentemente, não havia vivido muito, mas na arrogância dos nossos vinte e poucos anos, assumimos inutilmente que compreendemos o mundo e tudo mais que nos cerca. Aprendi, de forma simples e dura, lições que minha família me poupara durante todo o período passado no seio daquele que era meu lar. Cresci, não em altura, pois sou aquela pequena de sempre. Cresci em confiança, em capacidade e amadureci. Aprendi que as coisas difíceis, são realmente muito difíceis e que as coisas simples, são também difíceis. Mas lidar com estas hoje é algo um pouco mais simples e normal.

Talvez tenha descoberto muitas coisas boas sobre mim mesma e sobre a minha capacidade de interagir com aquilo que me rodeia, as pessoas, as situações. O oferecimento desta tese foi também para os amigos, foi com eles que aprendi muitas coisas, boas e difícieis. Convivi com aqueles que tinham maior ou menor experiência na arte de viver longe, e com todos eles aprendi grandes lições. A minha família mesmo longe sempre me apoiou e evidentemente, nos momentos de maior fragilidade o estar "em casa" teve um significado jamais outrora compreendido. Muitas vezes sozinha e debilitada, tive a oportunidade singular de estar mais próxima de Deus e como isso foi importante neste período!

Eu aprendi tanto que decidi fazer tudo de novo: um novo lar, longe, bem...longe daquele que eu primeiro conheci. Geneva naquela "casinha" branca, tipicamente Yankee. Foi um ano também duro, muito duro, de muita adaptação, um novo país, um novo clima, clima frio...muuuito frio; novos amigos e a comida que saudaaades do Brasil... Novo laboratório, novos colegas, novo orientador, enfim, começara de novo. A essa altura eu já estava começando a me acostumar o com o NOVO. Muito trabalho e muito aprendizado.

O meu crescimento como ser humano foi assim, simples e duro. Entretanto, cresci também como aluna e cientista. Meu desenvolvimento acadêmico foi ímpar neste período e o aprendizado adquirido nos erros muito mais do que nos acertos pemitiram-me desenvolver uma visão científica mais crítica e realista. Os responsáveis sabem bem disso e essa tese talvez Ihes venha mostrar um pouco deste desenvolvimento.

E agora, em breve encontrarei um outro novo lar, talvez ainda como aluna ou não, mas com certeza aprenderei muito mais. Todavia, Piracicaba e Geneva foram para mim partes muito peculiares daquilo que nós usualmente chamamos de vida. Enfim, não queria deixar no olvido as pessoas importantes, mas somos seres humanos passíveis de erros. E como somos! E felizmente me faltariam páginas se eu fosse enumerar cada um de vocês. Só tenho a dizer muito obrigado a Deus e a todos vocês pelas vezes em que pude Ihes dizer, muito obrigado sem importar em que língua. 
A Deus pela vida, saúde, força, paciência e equilíbrio.

Ao Prof. Dr. João Lúcio de Azevedo pela orientação, incentivo e pelo exemplo de generosidade e competência.

Ao Prof. Dr. Randy William Worobo (department of Food Science and Technology NYSAES Cornell University Geneva-NYUSA) pela orientacao no exterior, ajuda na bancada, enorme paciência, incentivo e amizade. E ainda pelo completo suporte financeiro para o desenvolvimento do projeto no exterior.

Ao Prof. Dr. Wellington Luiz Araújo pela preciosa co-orientação no dia-a-dia, apoio e incentivo na realização desta tese.

À Profa. Dra. Andréa M. A. Nascimento (ICB/UFMG) pelo apoio (especialmente pelos e-mails diários), colaboração e incentivo em TODOS os momentos durante a realização desta tese.

À Profa. Dra. Aline A. Pizzirani Kleiner pelo sempre apoio, receptividade e gentileza tão inerentes a sua pessoa.

Ao Prof. Dr. Edmar Chartone de Souza (ICB/UFMG) pelo constante incentivo e amizade.

À Dra. Mariângela Hungria e a todos os queridos do Laboratório de Biotecnologia do Solo CNPS/EMBRAPA/Londrina$\mathrm{PR}$, pela inestimável ajuda e completa disponibilidade para os experimentos de seqüenciamento, em especial a Pamela Mena e ao Lourival Vilas-Boas (IAPAR - Londrina) pela ajuda na anotação.

Ao Prof. Dr. José L. C. Wolff e a todos do Laboratório de Virologia no NIB/UMC-Mogi das Cruzes-SP pela disponiblidade na realização de parte do seqüênciamento deste trabalho.

A todos os professores, colegas e funcionários do Depto de Genética da ESALQ/USP pela convivência e aprendizado.

A TODOS os colegas e funcionários do Laboratório de Genética de Microrganismos "Prof. João Lúcio de Azevedo"ESALQ/USP, uma ENORME e harmoniosa comunidade "endofítica" a qual tive o prazer de ser parte.

À bióloga Fabiana de Souza Cannavan do laboratório de Genoma do CENA/USP, pela ajuda na sonicação.

Aos colegas Adalgisa Ribeiro Torres, Maria Carolina Quecine, Maria Clara Pestana, e Uira Belmonte, pela ajuda nos experimentos finais desta tese.

Aos amigos e colegas do Food Microbiology laboratory Food Science \& Tech NYSAES Cornell University Geneva-NY-USA, pela convivência tão prazerosa e tranquila.

Aos amigos em Geneva: Jason, Rich, Randy, John, Cristina, Melissa, Armando, Marilu, Jose, Ben, Mohamed, Jub, Diego \& Romina \& ninõs, Lorenza \& Mickael que tornaram os meus dias em Geneva tão mais simples.

Aos caros, Cristina S. Maki, Taís G. Lana, Mayra K. Martins e Ricardo Yara pelas palavras de conforto e incentivo nos momentos tão necessários.

Ao querido amigo Fernando G. Barcellos e família, pelo amizade de sempre, orações e apoio por todos estes anos, e em especial durante minha recente estada em Londrina.

Às minhas queridas amigas em Belo Horizonte: Mônica B. Rodrigues, Flávia C. Nery, Sandra A. Carvalho pela amizade e carinho de SEMPRE.

Às minhas SUPER amigas em Piracicaba: Patrícia F. Cardoso, Kerlyng Cecchini e Gisa R. Torres pela amizade, incentivo e grande apoio nas alegrias, baladas e dificuldades.

To my dear Richard Wellington for being more than a friend, for your love, care and support in the most needing times.

À minha querida família por acatarem sempre com amor e completo apoio todas as minhas decisões, e por estarem comigo onde quer que eu esteja, pois onde quer que eu me vá, lhes levo mais do que nos genes, eu lhes levo no meu coração.

À Fundação de Amparo a Pesquisa do Estado de São Paulo (FAPESP) pelo financiamento do projeto no Brasil.

À Comissão de Aperfeiçoamente de Pessoal de Nivel Superior (CAPES) pela bolsa de estágio de doutorando no exterior (PDEE-Sanduíche).

Ao Conselho Nacional de Desenvolvimento Científico e Tecnológico (CNPq) pela taxa de bancada e bolsa de doutorado no Brasil. 


\section{SUMÁRIO}

Página

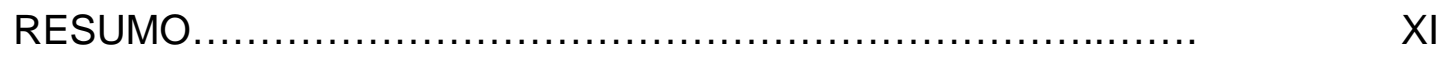

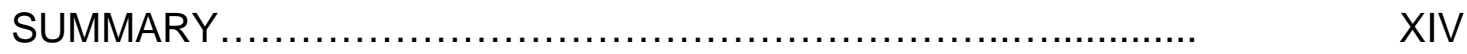

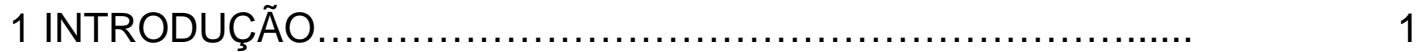

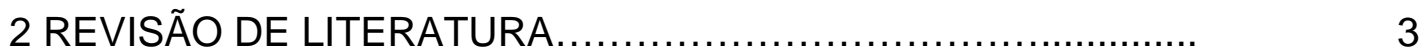

2.10 problema da Clorose Variegada dos Citros................... 3

2.1.2 Xylella fastidiosa como o agente causal da CVC............... 5

2.2 Interação entre bactérias endofíticas e $X$. fastidiosa................ 7

2.2.1 Bactérias endofíticas e seu uso no controle biológico........... 9

2.3 O Gênero Curtobacterium ................................... 10

2.3.1 Curtobacterium flaccumfaciens...........................

2.3.2 O status corrente da genética de C. flaccumfaciens........... 12

2.3.3 Aplicações e potencialidades de C. flaccumfaciens............. 15

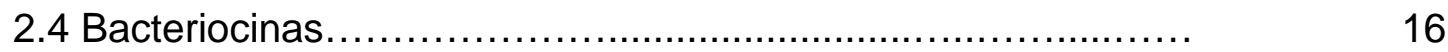

2.4.1 Bacteriocinas de bactérias Gram-positivas..................... 18

2.4.1.2 Modo de ação das bacteriocinas de bactérias Gram-positivas.. $\quad 20$ 
2.4.1.3 Estrutura genética das bacteriocinas de bactérias Gram-positivas..

2.4.1.4 Síntese, processamento e exportação das bacteriocinas de bactérias Gram-positivas

2.4.1.5 Imunidade as bacteriocinas de bactérias Gram-positivas....

2.4.2 Aplicações e perspectivas.

2.4.3 Bacteriocinas na agricultura

2.4.4. Bacteriocinas e $C$. flaccumfaciens

3 PRODUÇÃO DE SUBSTÂNCIAS INIBITÓRIAS DO TIPO BACTERIOCINA (SITB) POR LINHAGENS ENDOFÍTICAS DE Curtobacterium flaccumfaciens E Methylobacterium spp. E SUA INTERAÇÃO COM Xylella fastidiosa EM PLANTAS DE CITRUS...

Resumo

Summary

3.1 Introdução

3.2 Material e Métodos.

3.2.1 Bactérias, meios de cultivo e condições de crescimento......

3.2.2 Produção de SITB

3.2.3 Ensaios com SITB

3.2.4 Fatores que interferem na atividade das SITB.

3.2.5 Preparação do extrato cru das SITB 49

3.2.6 Análise Estatística. 
3.2.7 Índice de diversidade ................................. 49

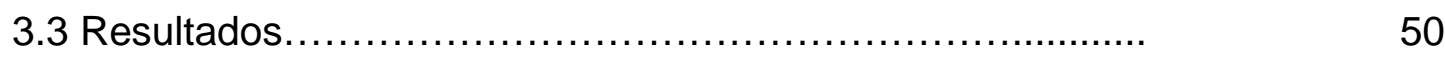

3.3.1 Produção de SITB por bactérias endofíticas de citros........ 50

3.3.2 Ação específica das SITB .............................. 54

3.3.3 Caracterização das SITB ................................ 55

3.4 Discussão................................................... 58

3.5 Conclusões.............................................. 64

4 CARACTERIZAÇÃO DA ENDOFICINA L UMA BACTERIOCINA

DO ENDÓFITO DE CITROS, Curtobacterium flaccumfaciens. 65

Resumo.................................................. 65

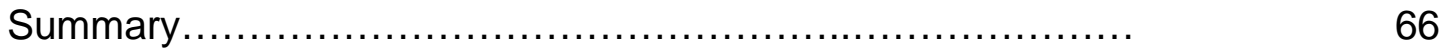

4.1 Introdução.................................................. 67

4.2 Material e Métodos..................................... 69

4.2.1 Bactérias e condições de cultivo......................... 69

4.2.2 Espectro de atividade .............................. 71

4.2.3 Produção da bacteriocina durante o crescimento e definição de unidade arbitrária..................................... 71

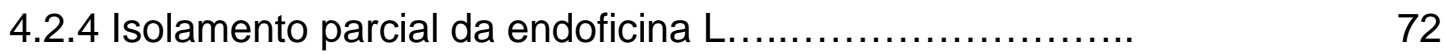

4.2.5 Eletroforese de proteínas.............................. 73 
4.2.6 Construção de uma biblioteca genômica de grande inserto de Curtobacterium flaccumfaciens ER1.4/2........

4.2.7 Varredura da biblioteca genômica de grande inserto para clones produtores de bacteriocina

4.2.8 Subclonagem e seqüenciamento......................... 75

4.2.9 Montagem da seqüência, anotação e análises das seqüências de DNA e proteína 77

4.3 Resultados. 78

4.3.1 Espectro de ação de C. flaccumfaciens ER1.4/2 ............. 78

4.3.2 Produção da endoficina $L$ durante o crescimento bacteriano.. 79

4.3.3 Análise bioquímica da endoficina $L$ 81

4.3.4 Obtenção da biblioteca genômica de grande inserto e seleção de clones cosmidiais

4.3.5 Obtenção da sub-biblioteca do clone L3391 e seqüenciamento do cosmídio

4.3.6 Anotação funcional do clone $L 3391 \ldots \ldots \ldots \ldots \ldots \ldots \ldots \ldots \ldots \ldots$

4.3.6.1 Análise predita de genes no operon da endoficina $L$

4.4 Discussão

4.5 Conclusões 
5 CONCLUSÕES GERAIS

REFERÊNCIAS BIBLIOGRÁFICAS... 


\title{
PRODUÇÃO DE BACTERIOCINAS POR ENDÓFITOS DE CITROS E CARACTERIZAÇÃO DA ENDOFICINA L DE Curtobacterium flaccumfaciens ENDOFÍTICO
}

\author{
Autora: LUCIANA CURSINO DOS SANTOS \\ Orientador: Prof. Dr. JOÃO LÚCIO DE AZEVEDO
}

\section{RESUMO}

Bacteriocinas são proteínas antimicrobianas produzidas por bactérias com importante papel na ecologia microbiana. Neste trabalho foram avaliados a produção e os efeitos destas proteínas numa fração da comunidade bacteriana de citros, pertencente aos gêneros Methylobacterium e Curtobacterium, isolada de Citrus sinensis (laranjeiras - plantas saudáveis, sintomáticas para CVC, assintomáticas para CVC) e Citrus reticulata (tangerina). Foi observada, para ambos os gêneros, uma alta freqüência de isolados produtores de bacteriocinas na comunidade endofíticas avaliada. Foi observado que esta freqüência foi maior em populações provenientes de plantas assintomáticas para CVC e em plantas de tangerina. Em Methylobacterium, as populações obtidas de plantas de tangerina e de plantas sintomáticas para CVC apresentaram uma maior 
freqüência de isolados produtores de bacteriocinas. Por outro lado, a população de Curtobacterium provenientes de plantas sintomáticas para CVC, apresentou a menor freqüência de isolados produtores bacteriocina. Proteínas de 3 isolados de C. flaccumfaciens foram parcialmente caracterizadas bioquimicamente, permitindo a sua classificação como bacteriocinas que foram denominadas de endoficinas. Uma destas bacteriocinas, a endoficina $L$ foi escolhida para ser melhor caracterizada. A endoficina $L$ parcialmente purificada apresentou um peso molecular estimado de $14 \mathrm{kDa}$ e atividade in gel, e atingiu seu nível máximo de produção na fase estacionária e foi ativa contra bactérias Gram-positivas e Gram-negativas, incluindo patógenos humanos e de plantas. Para a caracterização do gene envolvido na produção desta bacteriocina uma biblioteca, em cosmídeo, de fragmentos de DNA com $40 \mathrm{~kb}$ foi construída e um clone exibindo atividade bacteriocinogênica foi subclonado e parcialmente seqüenciado. Esta análise revelou um operon de 2,0 kb consistindo de pelo menos três genes preditos envolvidos na produção desta bacteriocina. Análises in silico sugeriram que a endoficina $L$ deva ser uma bacteriocina do tipo toxina que pode ser uma candidata em potencial como agente no controle biológico de X. fastidiosa e outros fitopatógenos. Os resultados obtidos sugerem que, quando C. flaccumfaciens produtores de bacteriocinas estão presentes em plantas de citros podem inibir $X$. fastidiosa. Por outro lado, o crescimento de $X$. fastidiosa parece ser favorecido pela presença de Methylobacterium a qual produz bacteriocinas contra Curtobacterium. A primeira interação poderia ser 
mediada por bacteriocinas como a endoficina L. Sugere-se uma interação cíclica entre tais microrganismos. O conhecimento da interação entre tais bactérias endofíticas representa um avanço no entendimento dos aspectos ecológicos da interação planta-microrganismo. 


\section{PRODUCTION OF BACTERIOCIN BY CITRUS ENDOPHYTES AND CHARACTERIZATION OF THE ENDOPHYCIN L FROM Curtobacterium flaccumfaciens ENDOPHYTIC}

Author: LUCIANA CURSINO DOS SANTOS Adviser: Prof. Dr. JOÃO LÚCIO DE AZEVEDO

\section{SUMMARY}

Bacteriocins are antimicrobial proteins produced by bacteria, which play a role in microbial ecology. In this work we examined the bacteriocin production and it effects under a citrus bacterial communities belonged to Curtobacterium and Methylobacterium genera isolated from Citrus sinensis (sweet orangeuninfected, symptomatic, CVC-asymptomatic) and Citrus reticulata (tangerine) . We found a high levels of bacteriocin production for both genera, these frequencies were higher in asymptomatic and tangerine plants. The highest production frequencies for Methylobacterium strains were from tangerine and symptomatic plants. C. flaccumfaciens strains from symptomatic plants presented the lowest bacteriocin frequency. Proteins from three strains of $C$. flaccumfaciens were partially biochemically characterized and further classified 
as bacteriocins termed endophycins. One of them the endophycin L, was picked for deep investigation. The endophycin L partially purified had a molecular weight estimated of $14 \mathrm{kDa}$ and exhibited in gel activity. Endophycin L production started at the exponential phase and reached its highest point during the stationary phase. It was capable of inhibiting the growth of Gram-positive and Gram-negative bacteria, incluiding several human and plant pathogens. In order to characterize the related to this bacteriocin production. One cosmid clone containing a $40-\mathrm{Kb}$ fragment from a genomic library of $\mathrm{C}$. flaccumfaciens was selected for its bacteriocinogenic ability The fragment was subcloned and DNA sequencing revealed a 2-kb operon consisting of at least three putative genes related to endophycin production. In silico analyses suggested that endophycin $L$ is a toxin-like bacteriocin, this bacteriocin could be a potential candidate as biological control agent against $X$. fastidiosa and other plant pathogens. The data indicated that when C. flaccumfaciens producers are present it inhibits $X$. fastidiosa, conversely $X$. fastidiosa growth seems to be favored by Methylobacterium species and the first interaction could be mediated by endophycins, such as endophycin L. Thus, we suggest a cyclic interaction among these microorganisms. We demonstrated that knowledge of the interaction among those endophytic bacteria represent an advance about plantmicroorganism ecological aspects. 


\section{INTRODUÇÃO}

A Clorose Variegada dos Citros (CVC) foi descrita como uma nova doença em citros no Brasil em 1987 (Rosseti et al., 1990). Somente mais tarde foi detectado que o seu agente causal era uma bactéria fastidiosa e restrita ao xilema, denominada Xylella fastidiosa. (Brlansky \& Hartung, 2002) As perdas econômicas geradas por essa doença, ao longo desta quase duas décadas, podem ser estimadas em 6 bilhões de reais, uma vez que as perdas anuais causadas pela CVC, na agroindústria do citrus, são de $R \$ 300$ milhões (Pashalidis et al., 2005). Infelizmente, até o momento não há uma forma de controle especifico contra o patógeno, fazendo-se necessário à implantação de estratégias de manejo em pomares contaminados, tais como a obtenção de novas mudas sadias e de poda, a fim de se evitar a disseminação da doença (Fundecitros, 2002). Em sistemas de produção agrícola intensiva, como a citricultura, um setor que gera anulamente ao país cerca de 1,5 bilhões de dólares em divisas por ano, a proteção contra fatores biológicos que influenciem de forma adversa na eficiência do cultivo, na qualidade microbiológica e comercial da cultura têm grande significância (Cesconetto, 2004). Diante da emergência da agricultura sustentável, métodos de controle têm sido reestruturados e revistos na última década. Assim, a importância de se fazer uso de métodos não-nocivos ao ambiente, bem como daqueles que são seguros do 
ponto de vista higiênico-alimentar, têm enfatizado os métodos de proteção baseados em agentes de origem biológica (Foldes et al., 2000). Dessa forma, os agentes biológicos com propriedades antagonistas têm recebido considerável atenção no controle de doenças de plantas, como alternativa aos pesticidas químicos. As bactérias que habitam as plantas estão expostas a microambientes altamente competitivos como a interface solo-raiz ou rizosfera, a filosfera e o sistema vascular. Nestes ambientes, as bactérias freqüentemente competem por nutrientes e nicho (Parret et al., 2003). Como conseqüência, tais organismos necessitam desenvolver ferramentas para a competicão intra e interespecífica, tais como a produção de antibióticos, enzimas degradativas e bacteriolíticas e bacteriocinas (Dong et al., 2004). Na competição por nutriente, por exemplo, a habilidade em produzir bacteriocinas confere uma distinta vantagem às bactérias que habitam o mesmo ambiente. Em plantas de citros, $X$. fastidiosa divide seu nicho ecológico com bactérias de diferentes gêneros como Bacillus, Burkholderia, Curtobacterium, Enterobacter, Methylobacterium, Pantoea, entre outros (Araújo et al., 2002) Neste microambiente, acredita-se que tais bactérias sejam capazem de interagir entre si, de forma antagônica ou sinérgica. O presente trabalho teve como objetivo (i) identificar e determinar a freqüência de produção de substâncias antagonísticas do tipo bacteriocina, por linhagens de Curtobacterium flaccumfaciens e Methylobacterium spp. endofíticas de citros, (ii) examinar os efeitos destas sobre a comunidade bacteriana de citros, (iii) analisar a interação destes endófitos produtores destas substâncias com X. fastidiosa (iv) selecionar bactérias endofíticas produtoras de bacteriocina capazes de inibir de $X$. fastidiosa in vitro $(v)$ caracterizar a proteína da bacteriocina responsável por esta inibição e (vi) identificar os genes que codificam tal bacteriocina. 


\section{REVISÃO DE LITERATURA}

\subsection{O problema da Clorose Variegada dos Citros}

Há 25 anos, o Brasil é o maior produtor mundial de citros. É responsável por mais de $35 \%$ da produção de frutos, $53 \%$ do suco de laranja e $80 \%$ do suco concentrado distribuído no mercado mundial, movimentando anualmente mais de 5 bilhões de reais (de Souza et al., 2003; Cesconetto, 2004). Entretanto, dados de 2001 têm mostrado que 36\% dos pomares produtivos no estado de São Paulo estavam apresentando sintomas da Clorose Variegada dos Citros (CVC), conhecida também por "amarelinho". (Fundecitros, 2002). No estado de São Paulo, cerca de 5 milhões de árvores sintomáticas são destruídas anualmente (Brlansky \& Hartung, 2002). Em citros, os sintomas da CVC incluem clorose intervenal (Figura 1a), redução no tamanho da folha, frutos duros e menores (Figura 1c). Em folhas maduras, são observados ainda pequenos pontos marrons na face inferior, na região correspondente à área clorótica na face superior (Figura 1b). Esta área pode com a evolução da doença, tornar-se marrom escura ou necrótica (Alves, 2003; Rosseti \& De Negri, 1990). Os aspectos econômicos mais importantes da CVC dizem 
respeito à maturação precoce dos frutos com a redução do tamanho dos mesmos, e principalmente o enrijecimento da casca, que pode causar danos às máquinas utilizadas na produção de suco, tornado tais frutos não-comerciáveis (Brlansky \& Hartung, 2002).

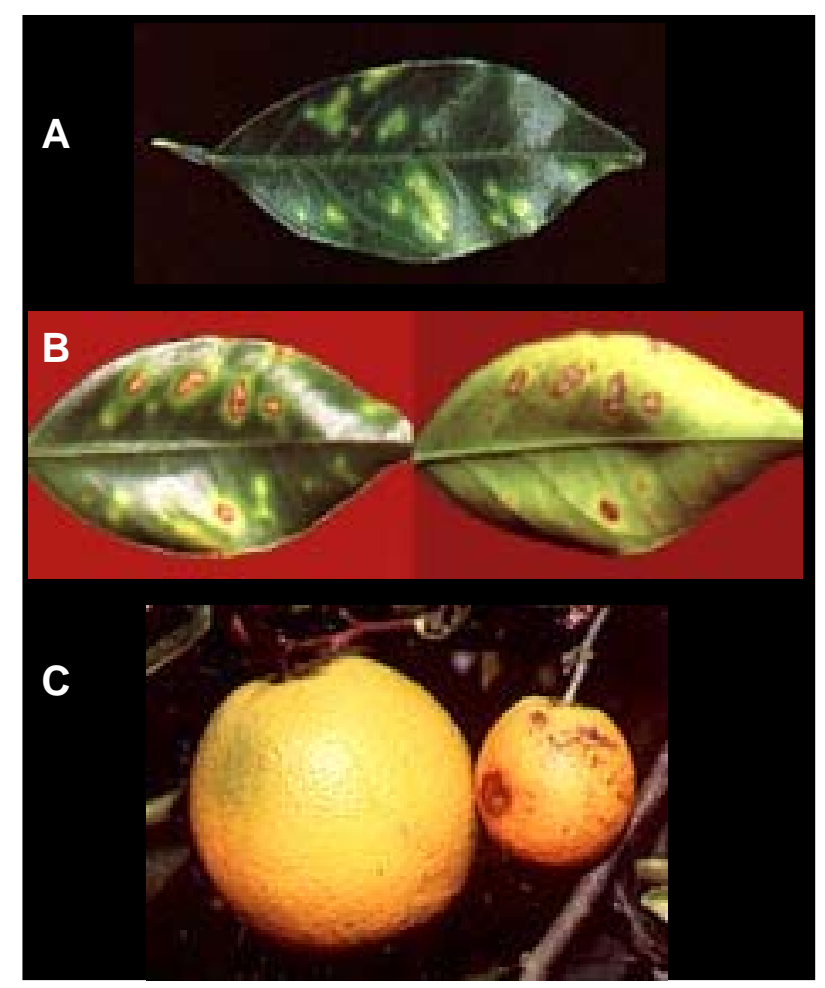

Figura 1 - Aspectos sintomatológicos da Clorose Variegada dos Citros em folhas e frutos de laranja. A e B, folhas sintomáticas. Em $C$, vê-se fruto sadio à esquerda, ao lado de fruto sintomático à direita (Parra et al., 2003) 


\subsubsection{Xylella fastidiosa como o agente causal da CVC}

A CVC é causada por Xylella fastidiosa, uma bactéria Gram-negativa, sem motilidade, limitada ao xilema (Rosseti et al., 1990; Brlansky \& Hartung, 2002, Chen et al., 2005). Ela é transmitida naturalmente por insetos sugadores (Hemiptera: Cicadellidae) que se alimentam da seiva bruta do xilema (Araújo et al., 2002). Em citros esta bactéria é capaz de infectar especialmente laranjasdoce, mas outros hospedeiros como tangerina, tangores ${ }^{1}$, $\operatorname{tangelos}^{2}$ e limão são observados (Laranjeira et al., 1998).

Segundo Alves (2003) ainda há divergências no que diz respeito a patogenicidade de $X$. fastidiosa em citros. Contudo, a hipótese mais bem aceita foi proposta Hopkins em 1995. De acordo com o autor, X. fastidiosa leva a disfunções no sistema condutor de água em plantas de citros. O principal mecanismo de patogenicidade seria a falta de translocação de água e nutrientes devido à oclusão de vasos do xilema pelos agregados bacterianos os devido a deposição de pectina e de goma fastidiana (Souza, 2002), em conjunto com reações de resistência da própria plantas. A reação de resistência mais comum das plantas de citros a CVC, seria a formação de tiloses ${ }^{3}$ pelo hospedeiro, resultando em estresse hídrico (Alves, 2003, Fry \& Milholland, 1990). Outras reações de resistência da planta à entrada do patógeno bacteriano também observadas são a formação de cristais de cálcio em vasos,

\footnotetext{
${ }^{1}$ Planta híbrida de citros produzida pelo cruzamento de plantas de tangerina (Citrus reticulata) com plantas de laranja (Citrus sinensis).

2 Planta híbrida de citros produzida pelo cruzamento de plantas de tangerina (Citrus reticulata) com pomelo (Citrus paradisi).

${ }^{3}$ Supercrescimento de células parenquimáticas para dentro da parede de um vaso, levando ao entupimento parcial ou total do lúmem do mesmo.
} 
que possivelmente levariam à destruição das membranas da pontuação, causando cavitação nos vasos com embolia (Alves, 2003; Shultz \& Matthews, 1988).

Segundo Costerton \& Irvin (1981), a formação de agregados de células de $X$. fastidiosa dever-se-ia à liberação de polissacarídeos extracelulares que facilitariam a adesão célula-célula.

De acordo com Alves (2003) e Leite et al. (2002), a ocorrência de plantas com deficiências nutricionais, ainda que apresentem poucos vasos oclusos, pode ser devida à presença per se de agregados de $X$. fastidiosa. Tais agregados poderiam funcionar como uma rede atraindo íons nutrientes para si nestas plantas afetadas.

Os mecanismos de patogenicidade de $X$. fastidiosa em citros foram um dos enfoques do projeto Genoma Funcional de X. fastidiosa da Agência de Fomento à Pesquisa do Estado de São Paulo (FAPESP). Este projeto trouxe novas e valiosas informações a respeito dos importantes mecanismos desta doença. Em especial, Souza et al. (2005) apontam que a formação do biofilme por $X$. fastidiosa dentro dos vasos da planta com posterior bloqueio no sistema de água é causa da patogenicidade desta bacteria em citros. 


\subsection{Interação entre bactérias endofíticas e $X$. fastidiosa}

As bactérias endofíticas foram descobertas por Darnel em 1904. Desde então, pesquisadores têm definido endófitos de várias formas, as quais dependem da perspectiva de onde estes endófitos têm sido isolados e estudados (Tan \& Zou, 2001, Lodewyckx et al., 2002). Contudo, de acordo com Strobel \& Daisy (2003), a definição mundialmente aceita para endofíticos, e bem estabelecida por Bacon \& White (2000), é de que bactérias endofíticas são aquelas isoladas de tecidos vegetais internos sem causar nenhum dano imediato ao hospedeiro.

O estudo da interação entre bactérias endofíticas e patógenos de citros teve início em 1996, quando Araújo e colaboradores publicaram os resultados do primeiro isolamento de bactérias endofíticas de porta-enxertos de citros. As principais bactérias endofíticas isoladas neste trabalho foram Alcaligenes sp., Bacillus spp., Burkholderia cepacia, Curtobacterium flaccumfaciens, Enterobacter cloacae, Methylobacterium extorquens, e Pantoea agglomerans (Araújo et al., 2001). Somente no início desta década, Araújo (2000) avaliou a associação entre a comunidade bacteriana endofítica de Citrus sinensis (Laranja Natal) e a presença de plantas resistentes a CVC, por técnicas moleculares e microbiológicas. O autor observou que a bactéria endofítica Curtobacterium flaccumfaciens foi isolada principalmente de plantas escape ou assintomáticas, enquanto que Methylobacterium spp. foi isolada principalmente 
de plantas doentes. Pela primeira vez, foi cogitada a possibilidade do controle biológico da CVC por meio de tais bactérias.

Recentemente, Araújo e colaboradores (2002) estabeleceram hipóteses a respeito da interação entre bactérias endofíticas e $X$. fastidiosa suportadas por experimentos in silica, in vitro, e in planta. Segundo os autores, a CVC poderia desempenhar um papel no estabelecimento de Methylobacterium spp. na planta hospedeira. Esta hipótese seria endossada pela análise da diversidade de Methylobacterium spp. pois este gênero foi o mais freqüentemente isolado de plantas sintomáticas. Além disso, Araújo e colaboradores observaram um efeito sinergístico de Methylobacterium spp. no crescimento de $X$. fastidiosa (Dados não publicados). Por outro lado, a presença da bactéria endofítica $C$. flaccumfaciens em tecidos internos de plantas assintomáticas de citros, que hospedam $X$. fastidiosa, poderia estimular a produção de compostos ou elicitar, de alguma forma, um aumento na resistência destas plantas a $X$. fastidiosa. Assim, este endófito poderia estar limitando o estabelecimento de $X$. fastidiosa em plantas assintomáticas. Contudo são necessários mais estudos para se compreender melhor os mecanismos envolvidos neste processo. 


\subsubsection{Bactérias endofíticas e seu uso no controle biológico}

O uso de bactérias endofíticas de diversos hospedeiros vegetais no controle biológico de patógenos microbianos, insetos e nematóides, em culturas de importância econômica, tem sido amplamente estudado nos últimos 30 anos (Araújo et al., 2000; Hoitink \& Boehm, 1999). O controle biológico de doenças causadas por Erwinia carotovora sp. carotovora em repolho chinês no Japão tem sido realizado utilizando-se linhagens endofíticas de Erwinia carotovora (Kyeremeh et al.,1999; Kikumoto, 2000). Plantas de tomate e de canola infectadas com Fusarium oxysporum sp. lycopersici e Verticillium dahliae foram protegidas de qualquer infecção por bactérias endofíticas isoladas de canola (Nejad \& Johnson, 2000). Em batatas, doenças causadas por Clavibacter michiganensis têm sido controladas por diferentes bactérias endofíticas (Chanway, 1998). Nesta mesma cultura, têm se buscado novas bactérias endofíticas para o controle de doenças causadas por fungos (Berg et al., 2005). Actinobactérias endofíticas têm sido utilizadas no controle biológico de doenças causadas por Rhizoctonia solani e Gaeumannomyces graminis var. tritici em trigo, com ótimos resultados em campo (Coombs et al., 2004). Já em milho, uma série de diferentes bactérias endofíticas dos gêneros Arthrobacter, Azotobacter, Pseudomonas e Bacillus demostraram serem bons antagonistas no biocontrole de Fusarium verticillioides (Cavaglieri et al., 2004). Pseudomonas endofítica de cebola demonstrou controlar o patógeno Botrytis cinerea, assim 
como levar à promoção de crescimento em plantas de videira (Barka, et al., 2002). Constantemente isolam-se diferentes bactérias endofíticas com potencial para o controle doenças em culturas importantes e espera-se um futuro ainda mais promissor para o controle biológico com tais organismos.

\subsection{O Gênero Curtobacterium}

As bactérias do gênero Curtobacterium ocorrem naturalmente em plantas (Mocali et al., 2003; Behrendt et al., 2002, Zinniel et al., 2002), ainda que algumas espécies possam ser encontradas no solo (Koneva \& Kruglov, 2001) e em petróleo cru (Lizuka \& Komagata, 1965) e mais recentemente foi detectada como espécime clínica humana (Funkle et al., 2005). Tais bactérias apresentam-se em culturas frescas, como bastonetes Gram-positivos, pequenos, curtos e irregulares de tamanho aproximado de $0,4-0,6 \mu \mathrm{m} \times 0,6-$ 0,3 $\mu \mathrm{m}$. Podem se arranjar em pares ou células únicas, mas freqüentemente apresentam uma formação em V. Apesar de serem Gram-positivos, células em culturas antigas se descoram facilmente. Usualmente apresentam motilidade por flagelo do tipo peritríquio. Não produzem esporos ou grânulos metacromáticos. Mostram-se como colônias lisas, brilhantes e convexas, usualmente amarelas ou laranjas em ágar nutriente, nas suas temperturas ótimas de $25^{\circ} \mathrm{C}$ a $30^{\circ} \mathrm{C}$. São aeróbios obrigatórios, catalase positivos e considerados quimiorgatróficos, mas este não é necessariamente seu único 
requisito nutricional. Apresentam metabolismo respiratório, produzindo pequenas quantidades de ácido a partir de glicose (Garrit, 2004).

\subsubsection{Curtobacterium flaccumfaciens}

O gênero Curtobacterium compreende, no seu stricto sensu, seis espécies: C.albidum, C.citreum, C.flaccumfaciens, C. luteum, C. plantarurm e C. pusilum (Garrit, 2004). As espécies fitopatogênicas de C. flaccumfaciens são divididas, até o momento, em seis patovares. O sétimo e novo patovar foi sugerido recentemente por Young et al. (2004), mas ainda não está regulamentado pela Comissão Judicial de Nomenclatura Bacteriana. Segundo Dye et al. (1980), patovar é uma linhagem ou um conjunto de linhagens com características iguais ou semelhantes, que podem ser diferenciadas em níveis infrasubespecíficos de outras linhagens da mesma espécie ou subespécie, tendo por base a distinta patogenicidade a um ou mais hospedeiros vegetais. Tais divisões em C. flaccumfaciens ocorrem para propósitos de quarentena, uma vez que estes patovares podem causar doenças vasculares em feijão e soja (pv. flaccumfaciens), beterraba (pv. betae), tulipas (pv. oortii). Podem também causar cancro em euforbiaceas (pv. poinsettiae) (Garrit, 2004), além de doenças em espinafre (pv. basellae) (Guo, et al., 2003), beterraba açucareira (pv. beticola) (Chen et al., 2003) e Ilex opaca (pv. ilicis) (Young et al., 2004). 
Em meio sólido, isolados de C. flaccumfaciens apresentam-se como células móveis, amarelas, laranjas ou rosadas, capazes de hidrolizar caseína e assimilar ácidos como lático, málico e glucônico (Garrit, 2004). Além disso, mostram atividade celulolítica, sendo capazes de utilizar fibras naturais, tais como linho e sisal, como fonte de carbono (Lednicka et al., 2000).

Isolados de C. flaccumfaciens são encontrados como endófitos em vasos do xilema de laranja-doce, tangerina (Araújo et al., 2002) e limão (Gardner et al., 1982), sendo também capazes de colonizar a endosfera de plantas jovens de batata (Krechel et al., 2003) e a filosfera de amendoim (Jacobs \& Sundim, 2001), ervas daninhas (Vidaver, 1982), beterraba (McQuilken et al., 1993) e trigo (Legard et al., 1994). Esta bactéria foi ainda identificada no intestino de uma múmia-mastodonte de doze mil anos (Rhodes et al.,1998) e na árvore de acer do Canadá (Acer saccharum) durante a extração do xarope desta árvore (Lagacé et al., 2004).

\subsubsection{O status corrente da genética de $C$. flaccumfaciens}

Apesar da espécie C. flaccumfaciens já ter sido descrita por Hedges desde o início do século passado (Collins \& Jones, 1983) existem poucos estudos sobre os aspectos genéticos desta bactéria. C. flaccumfaciens é um organismo com alto conteúdo de G+C em seu genoma: 71-73mol\% (Döpfer et al.,1982). O exato conteúdo ainda não está bem estabelecido, uma vez que os 
estudos de hibridação DNA-DNA foram realizados ainda nos anos 80. Além disso, esta bactéria faz parte da grande gama de procariotos que ainda não tiveram seu genoma seqüênciado. A análise filogenética desta espécie a enquadra como pertencente à classe Actinobacteria, da ordem Actinomycetales e da família Microbacteriaceae (Garrit, 2004).

Conforme dito anteriormente, pouco se sabe sobre os aspectos genéticos desta espécie. Somente 38 seqüências de nucleotídeos estão disponíveis em bancos de dados de acesso público, como o GeneBank ${ }$, http://www.ncbi.nlm.nih.gov:80/entrez/query.fcgi?db=Nucleotide (06 junho 2005) nos Estados Unidos. Das 38 seqüências, 61\% foram introduzidas últimos três anos. Contudo, somente dois acessos correspondem a genes. O gene cpn60, (no.AY263152) (Tabela 1) que codifica a proteína putativa chaperonina 60, com provável função de chaperona na célula (Hill et al., 2004). Entretanto, não há relatos sobre a clonagem deste gene, tampouco sobre a purificação desta proteína. Este gene pertence a C. flaccumfaciens pv. flaccumfaciens. O segundo gene, cuja seqüência foi introduzida em 2005 (acesso no. AJ84795) corresponde ao gene gyrB, o qual codifica a subunidade B da DNA girase de $C$. flaccumfaciens pv. poinsettiae (Richert et al., 2005). De uma forma geral, a maioria (60\%) destas seqüências referem-se a linhagens patogênicas pertencentes aos seis patovares já descritos anteriormente. Os demais correspondem a isolados de diversos ambientes como rizosfera, filosfera, nave espacial (La Duc et al., 2003), entre outros. Apenas duas seqüências são de 
isolados endofíticos, sendo um de citros (acesso no. AY081209) e outro de batata (acesso no. AJ581989).

Tabela 1. Seqüências de nucleotídeos depositadas no GeneBank ${ }^{\circledR}$, relativas a C. flaccumfaciens

\begin{tabular}{ccc}
\hline Tipo de seqüência & Número & País(es) de origem \\
\hline $\begin{array}{c}\text { 16S rRNA } \\
\text { parcial ou completa }\end{array}$ & 16 & Alemanha, Brasil, China, EUA e Itália \\
Investigação genômica & 6 & Itália \\
Região intergênica & 6 & China, Itália \\
16-23S rRNA & & Itália \\
Iniciadores de PCR & 6 & Desconhecido \\
(a jusante e a montante) & & Brasil \\
23S rRNA & 1 & Canadá \\
$\begin{array}{c}\text { Seqüência desconhecida } \\
\text { Gene cpn60 - }\end{array}$ & 1 & Alemanha \\
chaperonina 60 & 1 & 6 \\
Gene gyrB - subunidade B \\
da DNA girase \\
Total
\end{tabular}




\subsubsection{Aplicações e potencialidades de C. flaccumfaciens}

Análises fisiológicas e enzimáticas de C. flaccumfaciens nos dão evidências de que estes organismos podem ser um grupo em potencial para busca de metabólitos e enzimas (Dworkin, 2003). A grande maioria dos dados disponíveis encontra-se nos patovares $C$. flaccumfaciens como por exemplo, $C$. flaccumfaciens pv. flaccumfaciens, que é capaz de hidrolizar esteróides e poderia ser útil na transformacão destes (Charney, 1966). Os C. flaccumfaciens pv. betae produzem glicopeptídeos capazes de potencializar a síntese de interferon por células peritoneais, em camundongos BALB/c (Zaczynska et al., 1992). Outras bactérias identificadas como C. flaccumfaciens podem acumular grânulos de polifosfato e mostram atividade de adenilato quinase e polifosfato glinoquinase (Bark et al.,1993). Estas características poderiam ser aplicadas no complexo processo para a remoção de fosfato biológico do lixo (Dworkin, 2003).

A estratégia mais provável para o uso prático de C. flaccumfaciens está relacionada a seu modo de vida endofítico. Os endófitos são aqueles microrganismos capazes de habitar os biótopos chamados plantas superiores. Eles são considerados um reservatório para novos metabólitos secundários, oferencendo um potencial para a exploração médica, industrial e particularmente agrícola (Strobel \& Daisy, 2003). Atualmente, tais organismos estão sendo vistos como uma proeminente fonte de produtos naturais bioativos, especialmente porque há inúmeros endófitos que ocupam uma imensa gama de 
nichos biologicamente únicos, situados nos mais variados ambientes (Owen \& Hundley, 2004). Assim, estes fatores biotípicos parecem ser importantes na seleção dos endófitos pelas plantas hospedeiras, uma vez que esses fatores podem governar o caráter inovador e a atividade de produtos associados aos microrganismos endofíticos (Strobel \& Daisy, 2003). Em resumo, o simples fato de estas bactérias colonizarem uma série de culturas (Elbeltagy et al., 2000; Zinniel et al., 2002) sugere que possam ser usadas em aplicações futuras como na obtenção de enzimas degradativas para o controle de certas doenças em plantas e outros produtos úteis como aqueles responsáveis por promover o crescimento vegetal (Hallmann et al., 1997).

Utilizando-se desta estratégia, poder-se-ia permitir uma melhoria nas capacidades das plantas sem que estas necessitem da integração de DNA estranho ao seu genoma (Zupan \& Zambryski, 1995). Por outro lado, os Curtobacterium endofíticos poderiam também ser vistos como possíveis vetores de genes para a construção de plantas transgênicas, ainda que se necessite de mais estudos nesta área (Dworkin, 2003).

\subsection{Bacteriocinas}

As bacteriocinas são definidas de forma simples como proteínas biologicamente ativas que apresentam motivos com modo de ação bactericida (James et al., 1991). Contudo, esta família protéica inclui uma diversidade enorme de proteínas dos mais diversos tamanhos, mecanismos de ação e de 
imunidade (Riley \& Wertz, 2002). Tais proteínas têm sido encontradas em todos os grandes grupos de bactérias e, dentro das espécies, dezenas ou mesmo centenas de diferentes tipos de bacteriocinas são produzidas. Segundo Klaenhammer (1988), 99\% de todas as bactérias produzem pelo menos um tipo de bacteriocina. Porém, a única razão pela qual estas não têm sido isoladas, é o fato de que poucos pesquisadores têm procurado por elas.

As primeiras bacteriocinas descobertas por Gratia em 1925 foram as colicinas de Escherichia coli (Cursino et al., 2002a). Desde então, estas são tidas como o modelo para o estudo das bacteriocinas. De uma forma suscinta, as colicinas são capazes de matar uma célula sensível, por um processo que envolve ligação a um receptor, entrada na célula e ação bactericida. Esse mecanismo bactericida pode envolver a inibição da parede bacteriana, ação nucleásica ou formação de poro na membrana da bactéria (Cursino et al., 2002a). As bactérias colicinogênicas são especialmente protegidas contra as colicinas por produzirem de forma constitutiva uma proteína de imunidade, que se liga a colicina, inativando-a.

Sendo E. coli uma bactéria Gram-negativa, muitas das bacteriocinas de outras bactérias Gram-negativas em muito se assemelham `as colicinas. Após o descobrimento das bacteriocinas em bactérias Gram-positivas, outras novas características foram inseridas nesta diversa família de proteínas. 


\subsubsection{Bacteriocinas de bactérias Gram-positivas}

Klaenhammer (1993) dividiu as bacteriocinas de bactérias do ácido lático em quatro classes, de acordo com sua estrutura e características bioquímicas. Contudo, esta definição pode perfeitamente ser aplicada a outras bactérias Gram-positivas (Hu, 2003). Assim, as bacteriocinas de bactérias Gram-positivas podem ser divididas em classes I, II, III e IV. As bacteriocinas da classe I são pequenos peptídeos que agem na membrana e que possuem o aminoácido modificado lantionina (e por tal chamadas de lantibióticos). Tais peptídeos sofrem extensas modificações pós-traducionais antes de serem exportadas da célula. Tais modificações incluem desidratação de resíduos de serina e treonina originando didehidroalanina (Dha) e didehidrobutirina (Dhb), respectivamente e adição de resíduos de cisteínas via grupamentos SH em ligações $\mathrm{C}=\mathrm{C}$ de Dha e Dhb. As bacteriocinas da classe I podem ainda ser

subdivididas em A, B e C, de acordo com o seu modo de ação. Dentro desta classe se destaca a bacteriocina nisina, descoberta em 1928 (Roger, 1928). A nisina vem sendo, desde então, o modelo para as bacteriocinas de bactérias Gram-positivas.

As bacteriocinas da classe II são peptídeos pequenos, catiônicos e hidrofóbicos, de 20 a 60 aminoácidos, resistentes ao calor e não modificados pós-traducionalmente, exceto por pontes de dissulfeto (Dirix et al., 2004). Tais peptídeos também têm atividade na membrana e são caracterizados por um 
motivo Gly-Gly-X, no sítio de processamento do seu precursor (Hu, 2003). Esta classe é dividida em três subclasses, chamadas de Ila, IIb e Ilc, com base na sua estrutura primária. (Héchard \& Sahl, 2002).

Na classe Ila, estão peptídeos ativos contra as bactérias do gênero Listeria que exibem uma seqüência consenso YGNGVXC em seu N-terminal. $\mathrm{Na}$ classe Ilb estão contidos os complexos formadores de poro, constituídos de oligômeros de dois diferentes peptídeos. E o terceiro e último subgrupo, a classe IIc, é formada por bacteriocinas ativadas por tiol e secretadas via sistema sec -dependente, o qual será posteriormente explicado em detalhes (Ennahar, 2000).

A classe III é composta por bacteriocinas de maior peso molecular (>30KDa), sensíveis ao calor e, das quais, se tem pouca ou nenhuma informação sobre seu modo de ação (Héchard \& Sahl, 2002).

Na classe IV estão inseridos peptídeos complexos, que possuem motivos contendo lipídios ou carboidratos ( $\mathrm{Hu}, 2003)$. As bacteriocinas de bactérias Gram-positivas têm usualmente um espectro de ação mais largo que as colicinas, demonstrando essa eficácia, inclusive, contra bactérias Gramnegativas, vírus, assim como células eucarióticas (Riley \& Wertz, 2002; Wang et al., 2003). 


\subsubsection{Modo de ação das bacteriocinas de bactérias Gram-positivas}

As bacteriocinas de bactérias Gram-positivas são peptídeos que exibem uma grande variedade de estruturas químicas. Por isso, estas bacteriocinas afetam diferentes funções essenciais da célula bacteriana, como a transcrição, tradução, duplicação de DNA e biossíntese da parede celular (Oscáriz \& Pisabarro, 2001), ou mesmo causando estresse oxidativo nas células sensíveis (Eraso \& Inés, 2004). Contudo, a grande maioria age formando canais na membrana ou poros, que destroem o potencial energético das células sensíveis (Oscáriz \& Pisabarro, 2001). Ainda que apresentem uma grande variedade de mecanismos, a ação bactericida das bacteriocinas é surpreendente. Em muitos casos, tais compostos são capazes de inibir o crescimento da bactéria susceptivel a concentrações nanomolares (Diep \& Nes, 2002). Um aspecto bastante divergente entre bacteriocinas de bactérias Gram-negativas e Grampositivas é que estas últimas, usualmente, não necessitam do reconhecimento de um receptor na célula. De fato, a formação do poro na membrana da bactéria sensível ocorre após uma interação eletrostática inespecífica de aminoácidos carregados positivamente no N-terminal da proteína com fosfolipídeos de membrana, carregados negativamente. A porção C-terminal, por sua vez, participa da formação do poro transmembrânico por ser altamente hidrofóbica, como mostrado na Figura 2 (Oscáriz \& Pisabarro, 2001). 
Alguns autores, porém, acreditam que em certas bacteriocinas da classe Ila, sua atividade seja mediada por uma molécula do tipo receptor, como mostrado na Figura 3 (Ennahar et al., 2000; Riley \& Wertz, 2002). Neste modelo chamado de "ripa-barril", apesar de ser sugerida a presença de um receptor, ele também corrobora com modelos anteriores, que indicam interação de resíduos polares da bacteriocina com fosfolipídios aniônicos da membrana da bactéria sensível (Ennahar et al., 2000). Outras classes de bacteriocinas apresentam diferentes modos de ação. As da classe I levam à destruição da membrana celular e da parede bacteriana. A nisina, por exemplo, desestabiliza a bicamada fosfolipídica da célula-alvo, resultando num rápido efluxo de pequenas moléculas do citoplasma e conseqüente perda do potencial de membrana $(\mathrm{Hu}$, 2003). 


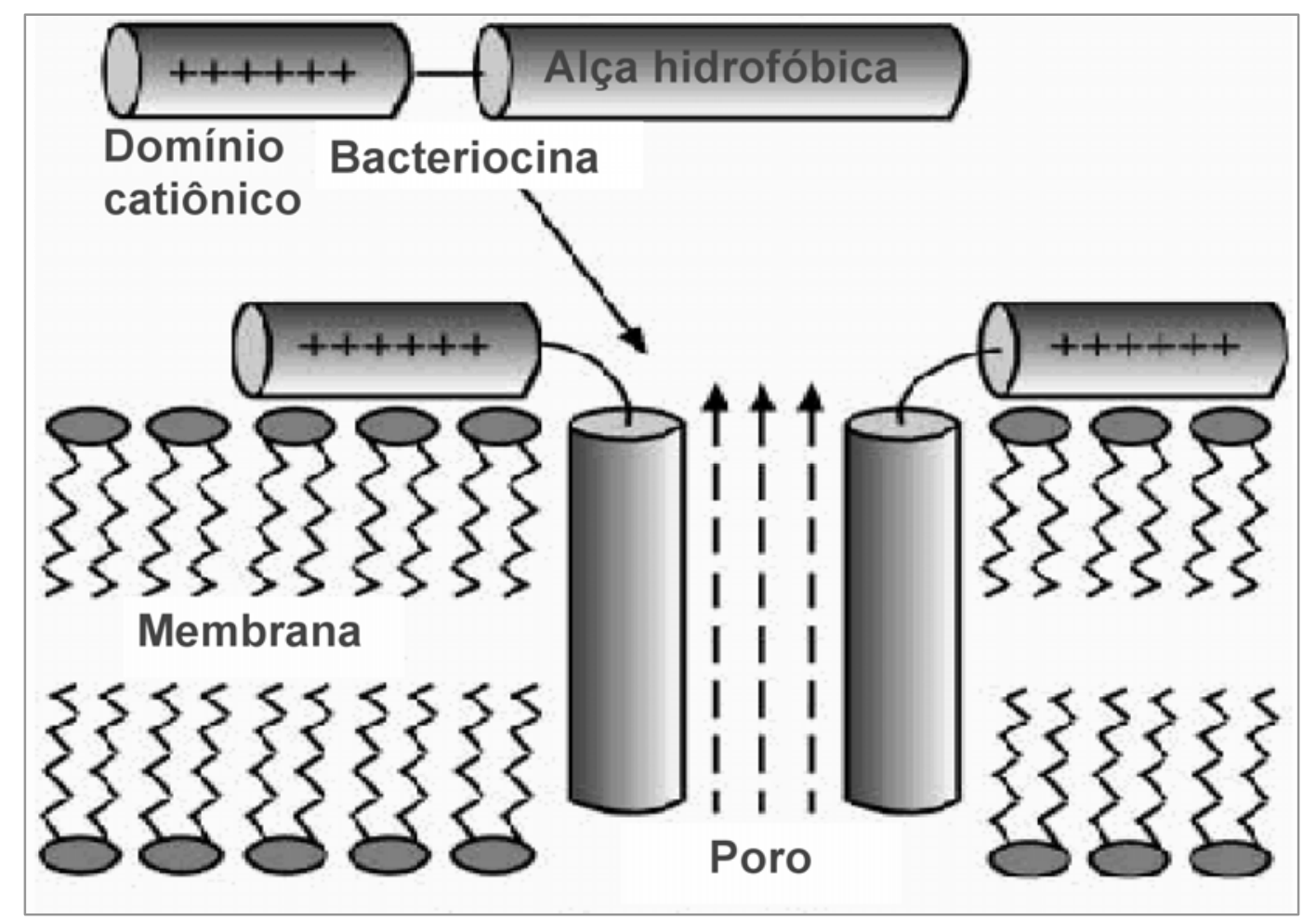

Figura 2 - Mecanismo de ação proposto para as bacteriocinas de bactérias Gram-positivas. Modelo referente à classe Ilc. (Oscáriz \& Pisabarro, 2001) 
A

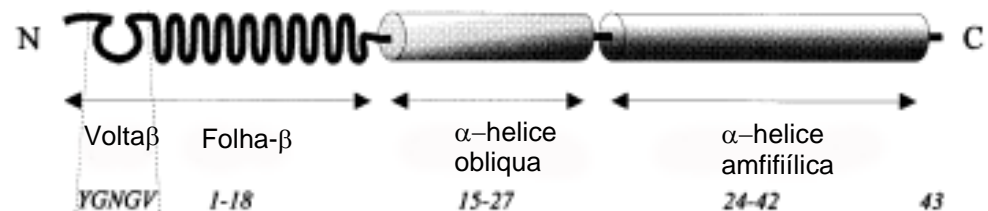

B

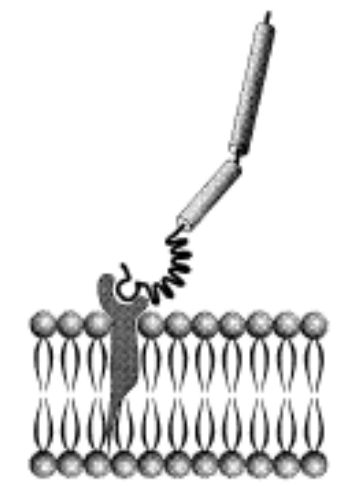

Posicionamento da bacteriocina

Dominio predito

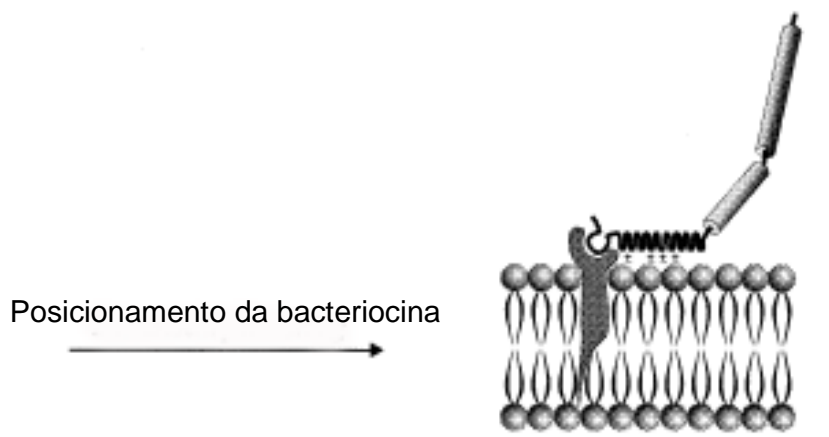

(1)

Reconhecimento do (provável) receptor

(2) Interação eletrostática

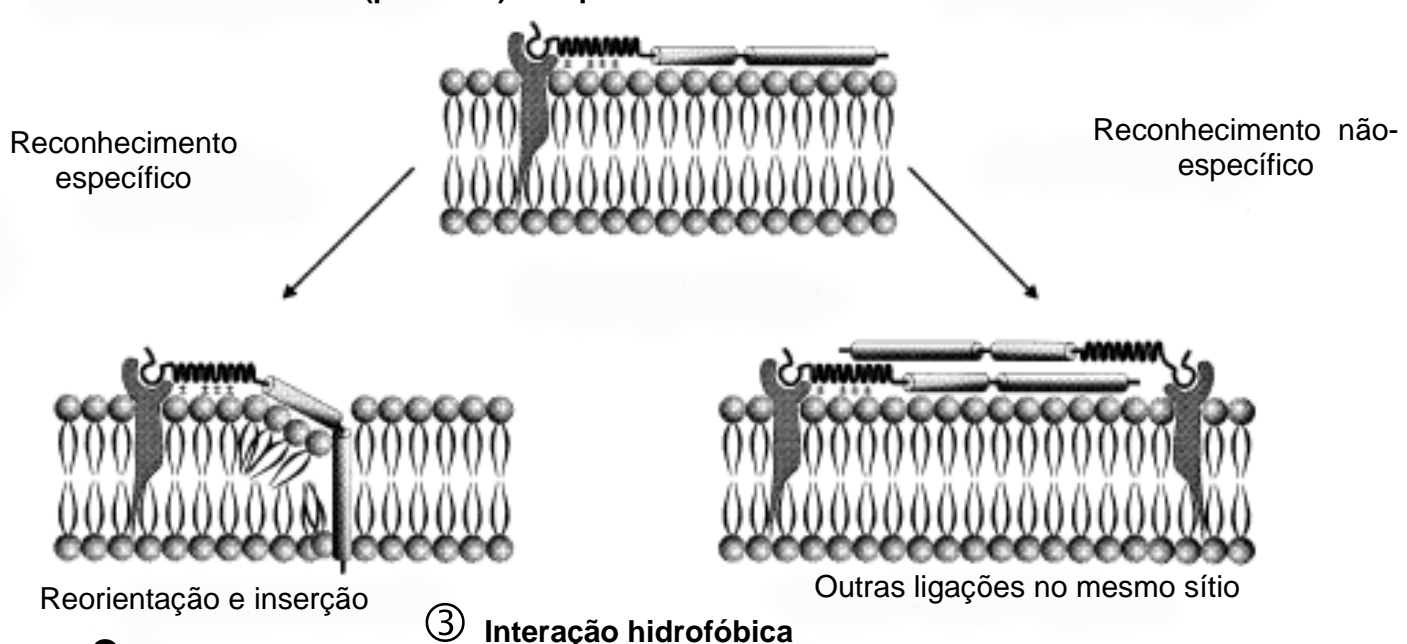

C

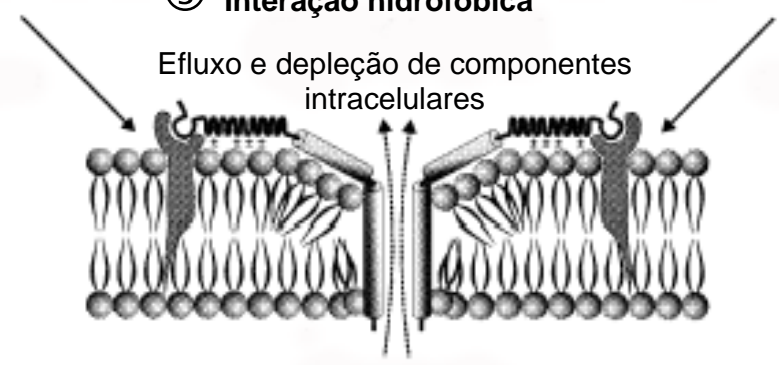

(4) Formação de Poro

Figura 3 - Representação esquemática da estrutura de um modelo de bacteriocina da classe Ila e a localização predita de seus domínios com relação ao alvo na membrana celular. (A) Os domínios estruturais preditos da bacteriocina; (B) possíveis interações de cada domínio com a superfície da membrana; $(C)$ inserção da bacteriocina e formação do poro hidrofílico. A face hidrofóbica do peptídeo está representada em preto, enquanto a face hidrofílica é cinza (Ennahar, 2000) 


\subsubsection{Estrutura genética das bacteriocinas de bactérias Gram-positivas}

As bacteriocinas de bactérias Gram-positivas são codificadas por genes freqüentemente presentes em plasmídios ou no cromossomo bacteriano, mas ocasionalmente podem ser encontrados em elementos móveis do tipo transposon ou DNA derivado bacteriófago (Diep \& Nes, 2002). A organização genética básica é bem conservada (Figura 4); contudo há uma grande variação em como os loci de bacteriocinas se organizam. Os genes são normalmente organizados em estruturas do tipo operons dentro dos conjuntos gênicos (Diep \& Nes, 2002). Os conjuntos gênicos das bacteriocinas podem ser constituídos de até 13 genes. Além dos genes estruturais da bacteriocina e genes de imunidade neste conjunto, também estão presentes genes que controlam as modificações pós-traducionais da bacteriocina, genes regulatórios e genes que codificam o aparato de exportação destas proteínas. Em alguns casos, ainda são encontradas outras fases abertas de leitura ainda não identificadas (Sahl \& Bierbaum, 1998; Riley \& Wertz, 2002). Convém ressaltar que a maioria, das bacteriocinas de bactérias Gram-positiva apresenta uma proteína de imunidade, a qual é codificada por genes que, via de regra, localizam-se próximos aos genes de biossíntese da bacteriocina ${ }^{1}$. Maiores informações a respeito destas proteínas de imunidade serão discutidas em itens subseqüentes. Freqüentemente, bacteriocinas de uma mesma classe apresentam semelhantes conjuntos gênicos para biossíntese de bacteriocinas como pode ser observado na Figuras 4 e $5^{1}$. Contudo, exceções podem ser encontradas.

\footnotetext{
${ }^{1} \mathrm{HU}, \mathrm{H}$;; MOAKE, M. M.; WOROBO, R. W. Genetic characterization of antimicrobial peptides. (Em elaboração)
} 
Nisina

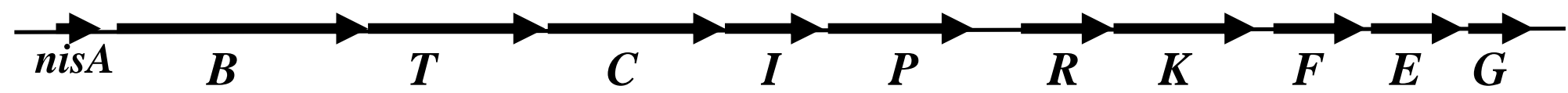

\section{Subtilina}

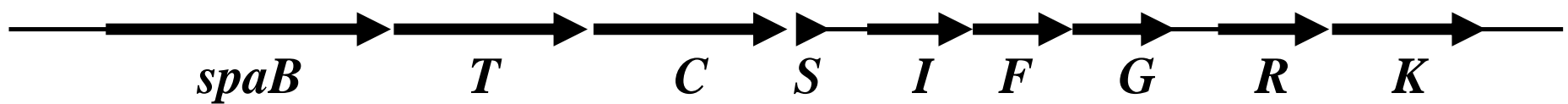

\section{Epidermina}

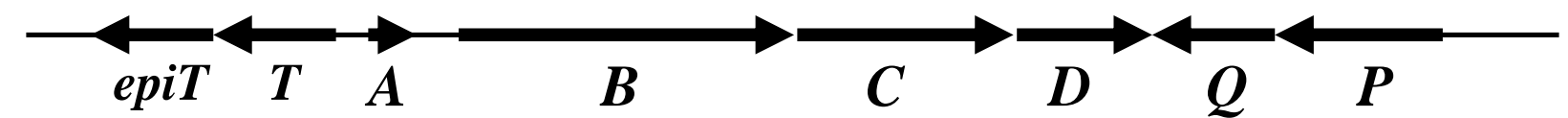

\section{Pep5}

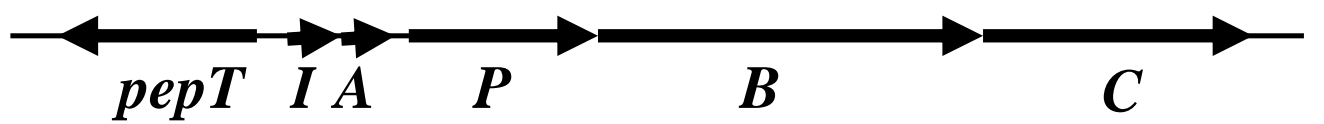

\section{Lactococcina DR}

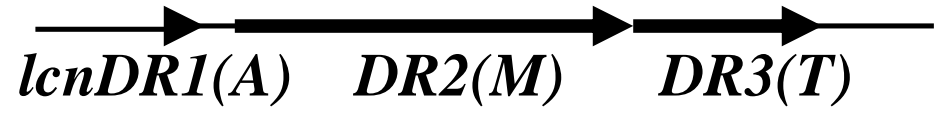

Figura 4 - Conjunto gênico das bacteriocinas da classe I, os lantibióticos. As setas indicam as fases abertas de leitura e sua direção de transcrição 


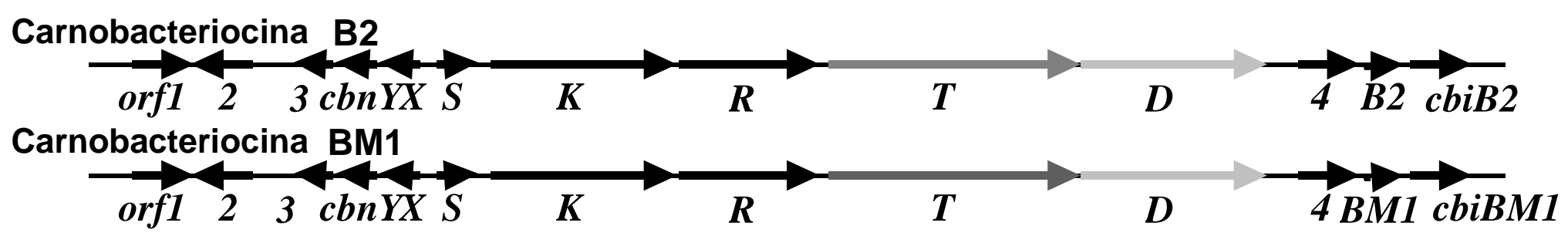

\section{Sakacina A}

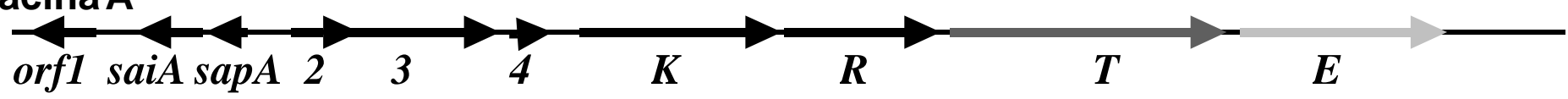

Sakacina $\mathbf{P}$

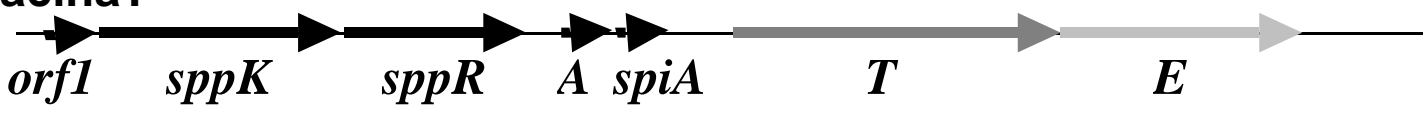

Leucocina A

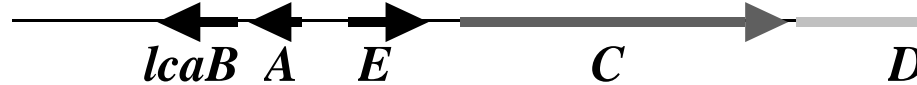

Mesentericina Y105

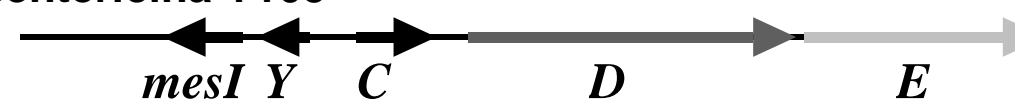

Divercina V41

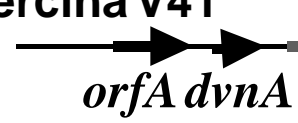

T1

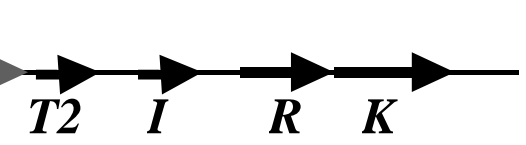

CurvacinaA

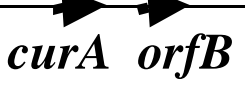

\section{EnterocinaP}

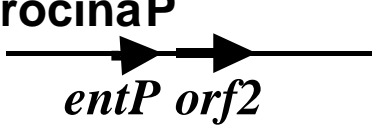

Enterocina $A$
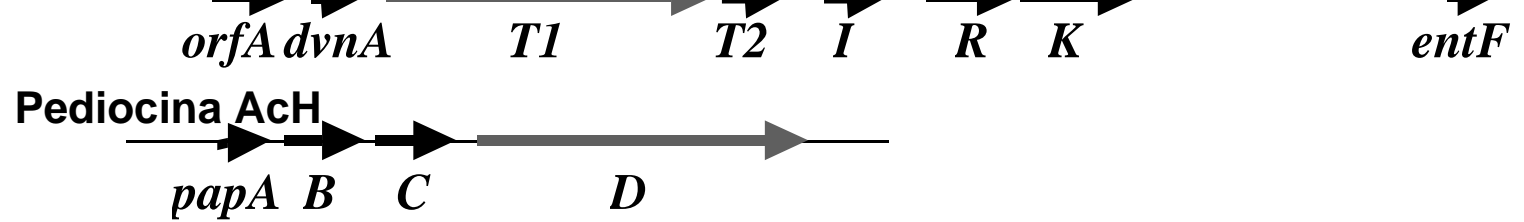

Figura 5 - Conjunto gênico das bacteriocinas da classe II. As setas indicam as fases abertas de leitura e sua direção de transcrição 


\subsubsection{Síntese, processamento e exportação das bacteriocinas de bactérias Gram-positivas}

As bacteriocinas de bactérias Gram-positivas mais bem estudadas com relação à síntese, processamento e exportação, são as da classe lla. Dados das outras classes são escassos e por vezes contraditórios. Tais bacteriocinas, tal como as outras bacteriocinas de baixo peso molecular, são sintetizadas ribossomicamente como precursores ou pré-peptídeos; estes aparentemente não exibem função biológica e contêm uma seqüência líder no seu N-terminal. A subseqüente clivagem do pré-peptídeo, num determinado sítio de processamento que remove a seqüência líder da molécula, é concomitante com sua exportação para fora da célula (Ennahar et al., 2000). As bacteriocinas são exportadas após sua produção por dois sistemas multiprotéicos comuns a bactérias Gram-negativas e Gram-positivas para a exportação de proteínas: o transportador $A B C$ e o sistema sec-independente. O transportador ABC ou cassete de ligação ao ATP (do inglês:"ATP $\underline{\text { Binding }}$ Cassete transporter") é um sistema que utiliza a energia da quebra do ATP para processar e transportar as bacteriocinas (Figura 6). Enquanto que o sistema sec-independente é um sistema multienzimático que acopla proteínas do tipo chaperonas e ATPases (Figura 7) para transportar proteínas, incluindo as bacteriocinas. O reconhecimento, o processamento e a exportação destas 
bacteriocinas por estes dois sistemas dependem de resíduos específicos de aminoácidos em cada proteína (Jack \& Jung, 2000).

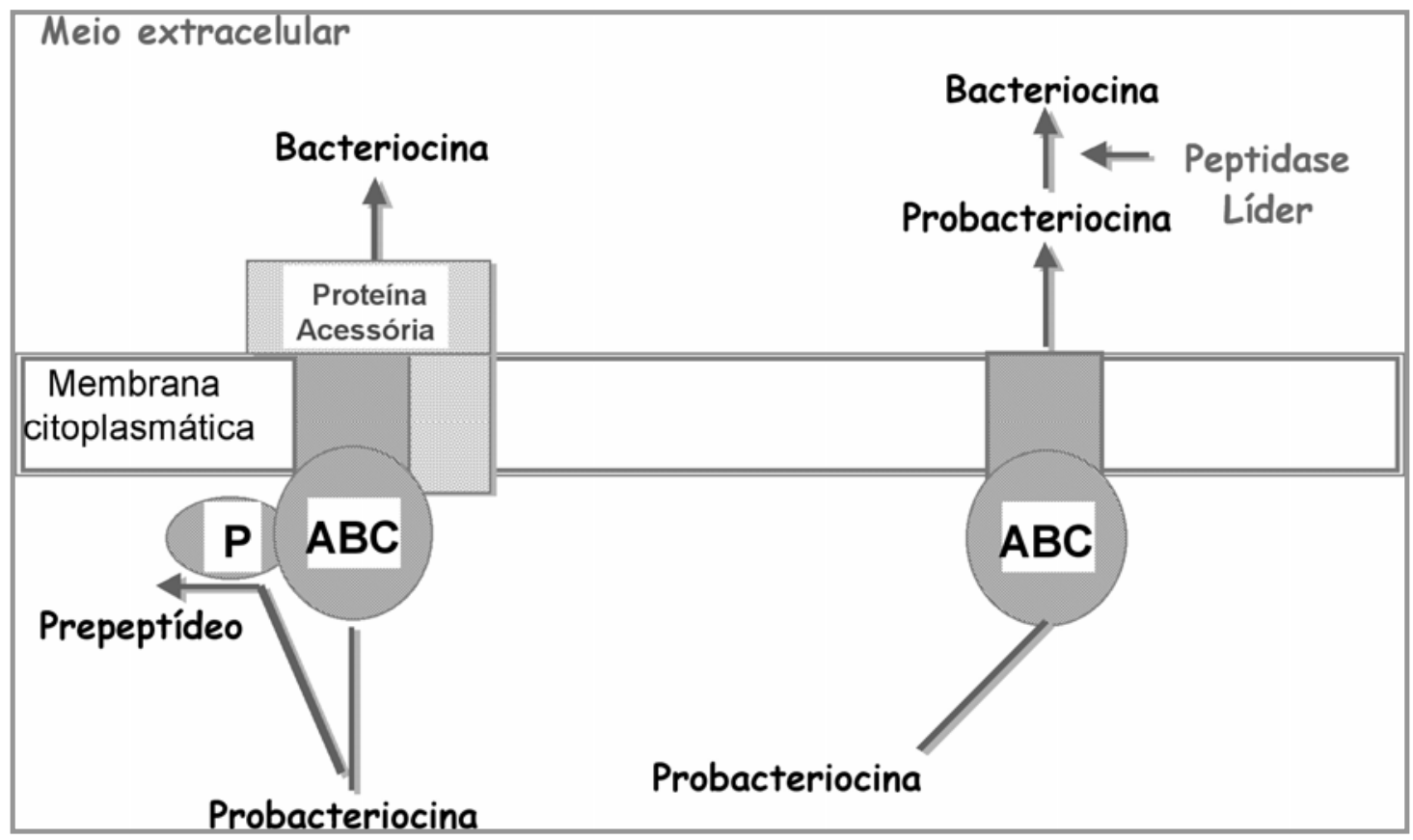

Figura 6 - Exportação de bacteriocinas via transportador $A B C$. À direita as probacteriocinas que têm um peptídeo líder são processadas pelo transportador $\mathrm{ABC}$, o qual exibe um domínio proteolítico P. A translocação da bacteriocina requer uma proteína de membrana adicional (proteína acessória). Existem bacteriocinas, como os lantibióticos à esquerda que exibem peptídeo líder diferenciado no seu N-terminal, que é somente clivado no meio extracelular, por uma peptidase líder específica (Wandersman, 1998) 


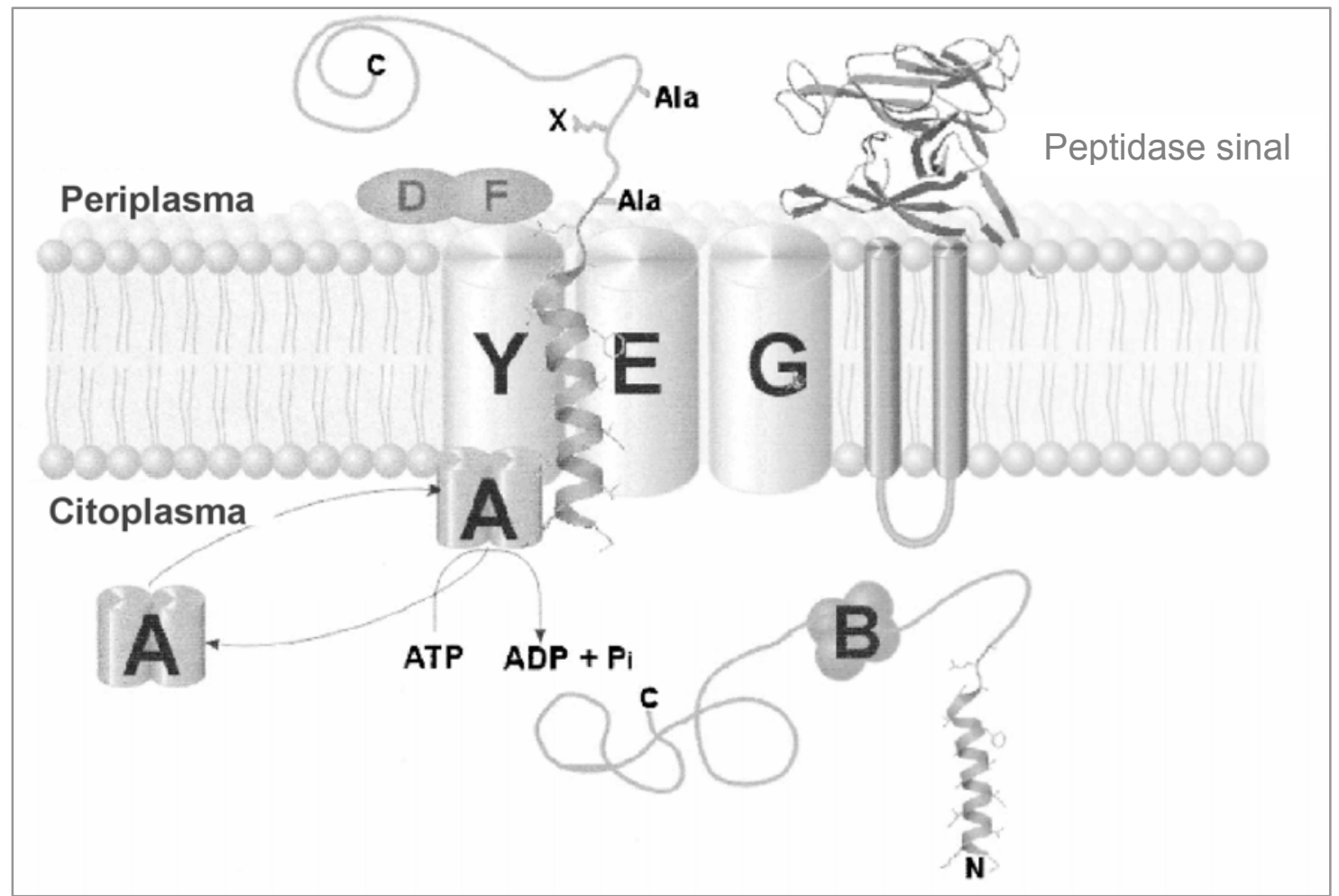

Figura 7 - Secreção de proteínas bacterianas exportadas através da membrana citoplasmática via sistema sec-dependente. A pré-bacteriocina ligase à chaperona de exportação $\operatorname{Sec} B(B)$. SecA (A), uma ATPase, direciona a pré-bacteriocina através da membrana pelo canal Sec YEG (YEG), utilizando a energia da hidrólise de ATP. Uma vez translocada através da membrana, a bacteriocina é processada pela peptidase sinal (Paetzel et al., 2000) 
A síntese das bacteriocinas da classe lla é induzida por um fator de indução $(\mathrm{FI})$, que é requerido como um sinal para transcrição do conjunto gênico da bacteriocina. Os FI são pequenos peptídeos catiônicos, hidrofóbicos e termorresistentes, os quais são também sintetizados como pré-peptídeos e que exibem suas próprias seqüências líder (Nilsen et al., 1998).

Acredita-se que um sistema de três componentes esteja envolvido no início da sinalização (FI, PKH e RR). Inicialmente, um excesso na concentração de FI, que ocorreria devido a uma lenta acumulação no meio extracelular, como conseqüência do crescimento bacteriano, seria o sinal inicial. Assim, o FI funcionaria como um sinal dependente de densidade celular (Ennahar, 2000). Tal mecanismo em bactérias recebe o nome de "quorum-sensing". Certos genes são ativados por peptídeos (em Gram-positivas) ou outras moléculas, como lactonas de homoserinas aciladas (em Gram-negativas), somente quando tais compostos atingem certas concentrações extracelulares durante o crescimento bacteriano (Miller \& Bassler, 2001; Smith et al., 2004). Sugere-se que o FI funcionaria como um indutor de uma proteína quinase de histidina $(\mathrm{PKH})$ presente na membrana da bactéria. Esta proteína, por sua vez, seria responsável pela fosforilação de uma outra proteína citossólica chamada de regulador de resposta $(R R)$, que após fosforilação se tornaria ativo e ativaria a expressão do conjunto gênico da bacteriocina (Ennahar, 2000)-Figura 8. Num sentido amplo, o regulador de resposta seria uma proteína do tipo fator de 
transcrição. Após a síntese da bacteriocina, bem como do $\mathrm{FI}$, ambos são processados e exportados para fora da célula (Figura 8).

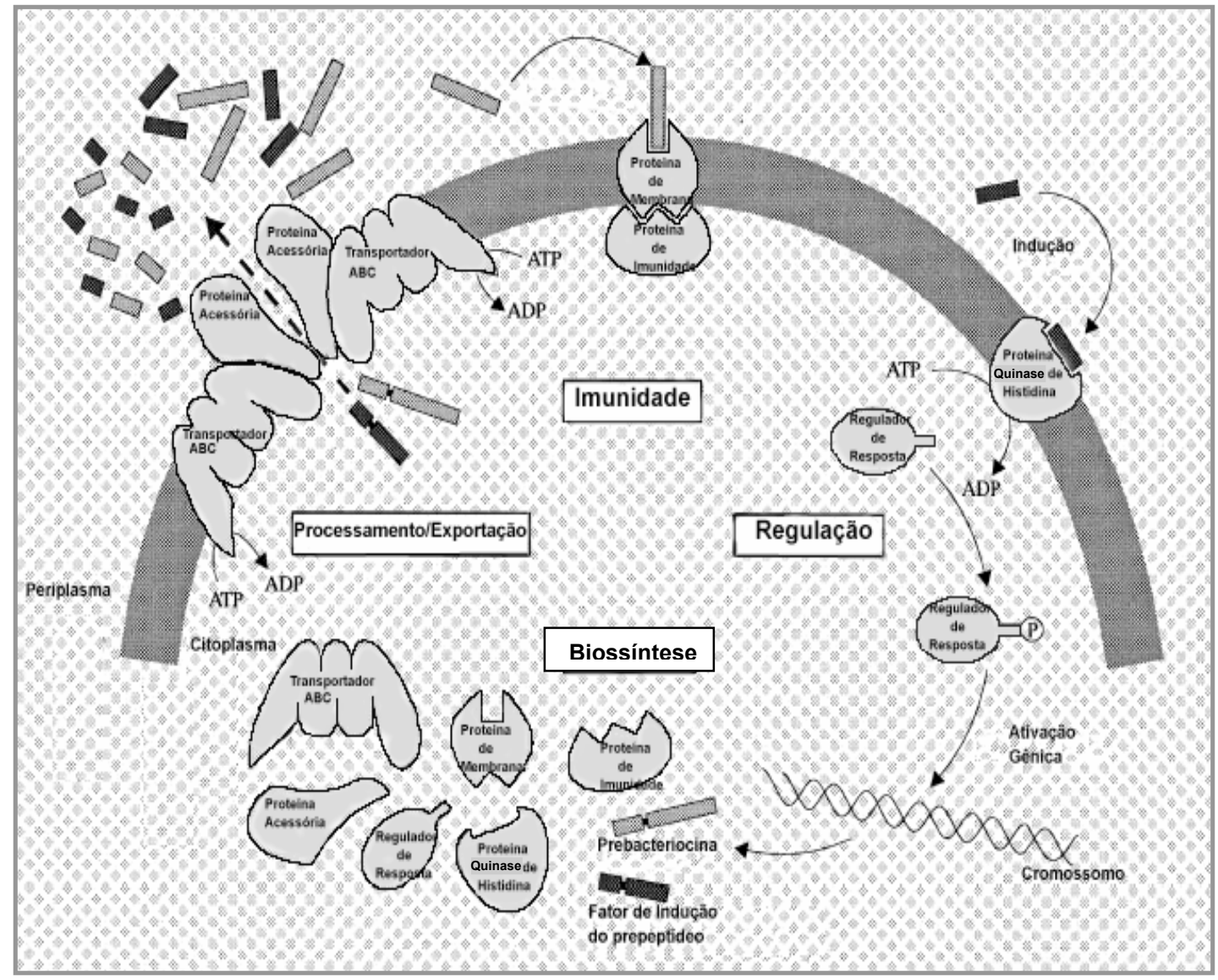

Figura 8 - Representação esquemática da maquinaria para a produção das bacteriocinas da classe Ila. Na figura está representado o sistema regulatório de três componentes (fator de indução, proteína quinase de histidina e regulador de resposta), além da síntese, processamento, secreção e a imunidade desta classe. A descrição de cada evento encontra-se detalhada no texto (Ennahar et al., 2000) 


\subsubsection{Imunidade `as bactericiocinas de bactérias Gram-positivas}

As bactérias produtoras de bacteriocina são especialmente protegidas contra as bacteriocinas que produzem. Esta proteção específica contra tais bacteriocinas deve-se à expressão de uma proteína de imunidade. Acredita-se que em bactérias Gram-positivas não ocorra uma interação direta entre a bacteriocina e a proteína de imunidade. Uma proteína de membrana faria a interação entre a bacteriocina e a proteína de imunidade, a qual inativaria a primeira, como mostrado na Figura 8 (Ennahar et al., 2000). A regulação gênica dos genes que codificam a proteína de imunidade é a mesma da bacteriocina.

\subsubsection{Aplicações e perspectivas}

Devido à ocorrência natural de bactérias Gram-positivas em alimentos várias destas espécies são tidas como de padrão alimentar (do inglês "food grade") ou GRAS- geralmente consideradas seguras (do inglês "Generally $\underline{R}$ egarded $\underline{\text { As }}$ Safe"). Assim, as bacteriocinas produzidas por estas bactérias podem ser incluídas nestas categorias (Hu, 2003).

Sugerem-se inúmeros usos para bactérias produtoras de bacteriocinas assim como para as próprias bacteriocinas purificadas. A bacteriocina mais utilizada mundialmente, inclusive no Brasil, na preservação de alimentos (derivados do leite, carne etc.) é a nisina, uma bacteriocina isolada da bactéria 
Gram-positiva Streptococcus lactis, que inibe uma série de bactérias patogênicas de alimentos (Cleveland et al., 2001). Além disso, a nisina tem sido utilizada por mais de 50 anos, em mais de 40 países, sem o desenvolvimento substancial de resistência (Xie et al., 2004). Além de sua aplicação na indústria de laticínios, a nisina tem sido testada como produtobase em formulações dermatológicas, agindo contra bactérias causadoras de infecções de pele (Eraso \& Inés, 2004). Outra bacteriocina utilizada na preservação de alimentos na indústria de carnes e laticínios é a pediocina, uma bacteriocina produzida pela bactéria Pediococcus acidilactici (Hu et al., 2004).

$\mathrm{Na}$ odontologia, uma série de bacteriocinas de bactérias Gram-positiva tem sido testada e acredita-se que, em breve, estarão disponíveis para tratamento e prevenção de cáries causadas por Streptococcus mutans (Balakrishnan et al., 2001).

$\mathrm{Na}$ medicina veterinária, o potencial terapêutico da bacteriocina purificada de Lactobacillus plantarum foi demonstrado em frangos infectados com E. coli patogênica, sendo que os frangos tratados com a bacteriocina foram negativos para colibacilose (Ogunbanwo et al., 2004). Em cães, espécies de Enterococcus, produtores de substâncias antagonistas do tipo bacteriocina foram capazes de inibir bactérias da família Enterobacteriaceae que freqüentemente causam infecções intestinais nestes animais (Strompfová et al., 2004a). Ainda em relação a estes animais, linhagens de Lactobaccilus foram capazes de exibir atividade probiótica em cães de 6 meses a 4 anos que 
apresentavam enteritite crônica e gastroenterite com hemorragia aguda (Strompvorá et al., 2004b).

$\mathrm{Na}$ medicina humana, com o crescente aumento da resistência a antibióticos em bactérias patogênicas, antimicrobianos alternativos aos clássicos antibióticos, como as bacteriocinas têm merecido particular atenção. Algumas destas bacteriocinas têm sido de grande utilidade na medicina, como a epidermina e gallidermina, ambas isoladas de bactérias do gênero Staphylococcus (S. epidermidis e S. gallinarum), que estão sendo empregadas no tratamento de infecções cutâneas (Hu, 2003). Ancovenina é uma bacteriocina isolada de Streptomyces sp. que age como um inibidor de enzimas que convertem a angiotensina, e portanto, têm um enorme potencial para o tratamento de doenças relacionadas à pressão arterial (Kido et al., 1983).

$\mathrm{Na}$ agricultura, a maior parte das bacteriocinas em uso experimental pertence a bactérias Gram-negativas, como as linhagens de Agrobacterium vitis (antigo radiobacter), produtoras da bacteriocina agrocina 84, capaz de controlar linhagens patogênicas de Agrobacterium (Parret \& De Mot, 2002). Contudo, há a perspectiva da ação de inúmeras outras bacteriocinas de bactérias Gram-positivas no controle de bactérias fitopatogênicas. Um exemplo é a bacteriocina de Bacillus thuringiensis, chamada de entomocina 9, que pode vir em breve a ser aplicada no controle de fitopatógenos como Fusarium graminis (Cherif et al., 2003). Mais recentemente Berg et al. (2005) descreveram isolados bacterianos Gram-negativos e Gram-positivos 
associados à batata, capazes de inibir Verticillium dahliaea e Rhizoctonia solani, dois importantes patógenos desta cultura.

As perspectivas reais para o uso comercial de bacteriocinas nas mais diversas áreas da biologia têm sido traduzidas no número de patentes registradas mundialmente envolvendo bacteriocinas e/ou suas linhagens produtoras. Das 210 patentes registradas, $56 \%$ foram obtidas de 2004 . E somente no primeiro quadrimestre de 2005, seis patentes relacionadas a bacteriocinas já foram concedidas (http://isi02.isiknowledge.com/portal.cgi?DestApp=DIIDW\&Func=Fr ame ) (6 jun. 2005).

\subsubsection{Bacteriocinas na agricultura}

Várias bactérias fitopatogênicas, que incluem os membros dos gêneros das Corynebacterium, Erwinia, Pseudomonas e Xanthomonas produzem bacteriocinas (Heu et al., 2001). Recentemente, a busca de novos agroquímicos que sejam altamente específicos e de baixa toxicidade e impacto ambiental, tem se tornado mais um aspecto de grande importância agrícola (Strobel \& Daisy, 2003). Uma vez que as bacteriocinas podem ser altamente específicas, produzidas a baixos custos e provavelmente muito seguras para o ambiente, elas parecem ser excelentes candidatas para uso na agricultura; especialmente no controle de fitopatógenos (Heu et al., 2001). No entanto, pouco é sabido sobre sua composição química, estrutura e modo de ação. Somente poucos isolados ou bacteriocinas purificadas de fitopatógenos têm 
sido relatados, como em Agrobacterium vitis, Corynebacterium ulcerans, Erwinia carotova subsp carotova, Pseudomonas syringae pv. syringae, Xanthomonas campesteris pv. glycines e X. campesteris pv. vesicatoria (Pham et al., 2004; Kim et al., 2004; Tudor-Nelson et al., 2003; Heu et al., 2001; Chuang et al., 1999; Smidt \& Vidaver, 1986; Abrehen \& Zamiri, 1985).

Se em fitopatógenos o cenário ainda é escasso, no que concerne às bactérias endofíticas, este se torna um campo aberto à exploração, sendo que somente uma bacteriocina de bactéria endofítica foi purificada. Esta bacteriocina pertence à bactéria endofítica de cana-de-açúcar Gluconacetobacter diazotrophicus e desempenha um papel na inibição de Xanthomonas albilineans, um patógeno vascular desta cultura. Trata-se de uma proteína do tipo lisozima, que atua lisando a célula do patógeno (Piñon et al., 2002). Contudo, os determinantes genéticos da bacteriocina de $G$. diazotrophicus ainda são desconhecidos. Convém ressaltar que o referido trabalho foi publicado no decorrer desta tese. Mesmo após a submissão do projeto que originou esta tese em 2001, nenhuma bacteriocina de isolados endofíticos havia sido relatada.

\subsubsection{Bacteriocinas e C. flaccumfaciens}

No final da década de 70 , Gross \& Vidaver (1979) descreveram a elevada freqüência (85\%) de produção de bacteriocinas sintetizadas por doze 
espécies de Corynebacterium fitopatogênicas. Este foi o primeiro trabalho de bacteriocinas com tais bactérias na área agrícola. Gross e colaboradores (1979) descreveram em seguida, plasmídios relacionados à producão de bacteriocinas nestas bactérias. Neste mesmo trabalho, os autores denominaram bacteriocinas de acordo com norma convencional (a qual sugere a utilização do nome da espécie ou gênero, seguido do sufixo ina). Então, seis bacteriocinas produzidas por linhagens patogênicas de Corynebacterium flaccumfaciens (hoje conhecidos como os patovares de Curtobacterium flaccumfaciens) foram denominadas de flaccumfacinas.

Este foi o primeiro e último relato a respeito das flaccumfacinas por aqueles pesquisadores. Recentemente, um grupo brasileiro tem trabalhado com linhagens bacteriocinogênicas de $C$. flaccumfaciens para fins de tipificação do patovar flaccumfaciens (Maringoni \& Kurozawa, 2002).

Diante do exposto, ainda que o relato de bacteriocinas em $C$. flaccumfaciens patogênicos tenha ocorrido a vinte e seis anos atrás, talvez por ausência de ferramentas bioquímicas e moleculares, ou de objetivos mais específicos, estas continuam, até o momento, a serem desconhecidas do ponto de vista bioquímico e genético. Os dois capítulos a seguir descreverão a identificação e caracterização bioquímica parcial e molecular de bacteriocinas de C. flaccumfaciens endofítico isolado de citros, que apresenta um potencial para o controle biológico da CVC. 


\section{PRODUCÃO DE SUBSTÂNCIAS INIBITÓRIAS DO TIPO BACTERIOCINA (SITB) POR LINHAGENS ENDOFÍTICAS DE Curtobacterium flaccumfaciens E Methylobacterium spp. E SUA INTERAÇÃO COM Xylella fastidiosa EM PLANTAS DE CITROS.}

\section{Resumo}

A Clorose Variegada dos Citros (CVC) causada pela bactéria Xylella fastidiosa, leva a perdas anuais de 100 milhões de dólares na indústria brasileira de citros. Estudos anteriores sugeriram que bactérias endofíticas de citros poderiam desempenhar um papel no controle da CVC. Neste trabalho foi investigada a producão de substâncias inibitórias do tipo bacteriocina (SITB) por 74 bactérias endofíticas de citros (Curtobacterium flaccumfaciens, Methylobacterium extorquens, $M$. fujisawaense, $M$. mesophilicum, $M$. radiotolerans e $M$. zatmanii), anteriormente isoladas de quatro tipos de plantas hospedeiras de Citrus sinensis (saudáveis, sintomáticas para CVC, assintomáticas para CVC) e Citrus reticulata (tangerina) e avaliar os efeitos destas SITB na comunidade bacteriana de citros. Resultados mostraram que 47\% das bactérias endofíticas produziram SITB in vitro. Produção de SITB foi 
observada para todas as espécies testadas, exceto $M$. radiotolerans. As freqüências de SITB foram maiores em bactérias isoladas de plantas assintomáticas para CVC (53\%) e de plantas de tangerina (69\%). As mais altas freqüências de produção de SITB por linhagens de Methylobacterium foram das bactérias provenientes de plantas de tangerina (73\%) e plantas sintomáticas para CVC (58\%). Linhagens de C. flaccumfaciens, provenientes de plantas sintomáticas para CVC, apresentaram a mais baixa freqüência de produção de SITB (17\%). Três linhagens de C. flaccumfaciens foram selecionadas para caracterização de suas SITB. A atividade de suas SITB foi sensível a proteases, ao tratamento com calor, assim como tiveram sua produção induzida por luz UV. Após outros testes, tais SITB foram classificadas como bacteriocinas e denominadas de endoficinas. Os dados sugerem que, quando C. flaccumfaciens produtores de SITB estão presentes eles inibem $X$. fastidiosa. Por outro lado, o crescimento de $X$. fastidiosa parece ser favorecido pela presença de espécies de Methylobacterium as quais poderiam inibir $C$. flaccumfaciens. A primeira interação poderia ser mediada por endoficinas. Deste modo, sugere-se uma interação cíclica entre tais microrganismos. Foi demostrado aqui que o conhecimento da interação entre tais bactérias endofíticas representa um avanço de como aspectos ecológicos da interação planta-microrganismo podem interferir na manifestação de doenças como a CVC. 


\section{Summary}

Citrus Variegated Chlorosis (CVC), caused by Xylella fastidiosa, lead to $\$ 100$ million-losses in the Brazilian citrus industry annually. Previous studies suggested a role of citrus endophytic bacteria controlling CVC. In this work we investigate the bacteriocin-like inhibitory substances (BLIS) production by 74 citrus endophytic bacteria (Curtobacterium flaccumfaciens, Methylobacterium extorquens, $M$. fujisawaense $M$. mesophilicum M. radiotolerans and M. zatmanii) previously isolated from four different citrus host plants (Citrus sinensis: uninfected, symptomatic, CVCasymptomatic and Citrus reticulata: tangerine) and examine the effects of these BLIS under citrus bacterial communities. Our results showed that $47 \%$ of endophytic bacteria produced BLIS in vitro, production was observed for all species tested, except M. radiotolerans. BLIS frequencies were higher in asymptomatic $(53 \%)$ and tangerine plants $(69 \%)$. The highest BLIS production frequencies for Methylobacterium strains were from tangerine $(73 \%)$ and symptomatic plants $(58 \%)$. C. flaccumfaciens strains from symptomatic plants presented the lowest BLIS frequency (17\%). Three strains of C. flaccumfaciens were chosen for further BLIS characterization. The BLIS activity of those bacteria was sensitive to proteases, heat treatment, as well induced by UV light and after further tests they were classified as endophycins. The data showed that when C. flaccumfaciens BLIS-producers are present it inhibits $X$. fastidiosa, conversely $X$. fastidiosa growth seems to be favored by Methylobacterium species and the first interaction could be mediated by endophycins. Thus, we suggest a cyclic interaction among these microorganisms. We demonstrated that knowledge of the interaction 
among those endophytic bacteria represent an advance about how plant-microbial ecological aspects may interfere in diseases such as CVC.

\subsection{Introdução}

A Clorose Variegada dos Citros (CVC) é umas das grandes preocupações da indústria cítrica brasileira. Somente no estado de São Paulo, aproximadamente cinco milhões de árvores doentes são destruídas anualmente, gerando um prejuízo em torno de 100 milhões de dólares. Árvores afetadas pela CVC apresentam sintomas severos de clorose nas folhas e frutos de tamanho reduzido (Lee et al., 1991). Dados econômicos não estão disponíveis; no entanto, a produção é extremamente reduzida e os frutos são pequenos e não-comerciáveis (Brlansky et al., 2002). A CVC é causada por Xylella fastidiosa; um patógeno bacteriano Gram-negativo, sem motilidade e restrito ao xilema. É transmitido por insetos sugadores que se alimentam do xilema (cigarrinhas, Hemiptera: Cicadellidae) e afeta culturas de grande importância econômica além de citros, como café, uva, pêssego entre outros (Nunes et al., 2003).

As doenças causadas por Xylella se enquadram na categoria de doenças emergentes, que ainda não foram observadas ou que surgiram recentemente e se tornaram problemas proeminentes e sem controle (Hopkins \& Purcell, 2002). Esforços recentes na busca de solução têm sido realizados 
pela comunidade científica, com o apoio da Fundação de Amparo a Pesquisa do Estado de São Paulo (FAPESP), que financiou o programa de seqüenciamento do genoma de $X$. fastidiosa, tal programa trouxe novas e importantes informações para se melhor entender o patógeno da CVC (Simpson et al., 2000).

Os endófitos incluem microrganismos simbiontes e comensais que não causam dano imediato na planta hospedeira; além de simbiontes mutualisticos que podem ser usados no controle biológico de patógenos ou para a promoção de crescimento da planta (Azevedo et al., 2000; Araújo et al., 2001). As bactérias Curtobacterium flaccumfaciens (Collins \& Jones, 1983) que são aeróbias Gram-positivas e as Methylobacterium extorquens, M. fujisawaense, M mesophilicum, M. radiotolerans e M. zatmanii (Brenner, 1984) que são aeróbias Gram-negativas, são encontradas como endófitos em ramos de laranja-doce (Citrus sinensis Osbeck cv. Natal) e tangerina (C. reticulata cv. Blanco) no Brasil (Araújo et al., 2002). O mecanismo pela qual estas bactérias entram nas plantas de citros ainda não foi esclarecido. Tais bactérias estão presentes nos vasos do xilema e compartilham o mesmo nicho ecológico com X. fastidiosa.

Várias bactérias associadas a plantas, e especialmente os fitopatógenos, produzem bacteriocinas, que são compostos proteináceos, sintetizados pelo ribossomo que são ativos, em geral, contra outras bactérias aparentadas. (Lavermicocca et al., 2002; Gross \& Vidaver, 1990). O 
fitopatógeno $X$. fastidiosa também apresenta genes que codificam bacteriocinas, bem como seus receptores (Simpson et al., 2000). As bacteriocinas matam as células sensíveis por um processo que envolve a ligação ou não a um receptor de superfície, com posterior entrada na célula, levando esta à morte por diferentes mecanismos de ação (Riley \& Wertz, 2002).

Dependendo de sua composição as bacteriocinas podem ter um espectro de ação mais amplo, mostrando-se bastante discrepante do típico modelo das colicinas (TMC) de bactérias da família Enterobacteriacea (Cursino et al., 2002a)

Devido a estas discrepâncias do TMC, alguns autores têm preferido aplicar a sigla SITB (para Substâncias Inibitórias do Iipo Bacteriocina) a fim de qualificar tais substâncias (Jack et al., 1995).

Recentemente, foi descrita uma bactéria endossimbionte de cana-deaçúcar produtora de uma bacteriocina ativa contra um patógeno nesta cultura (Pinõn et al., 2002). Assim, bacteriocinas poderiam ser usadas no controle biologico tomando como vantagem suas propriedades bactericidas específicas contra bactérias sensíveis (Jabrane et al., 2002).

Este estudo foi conduzido a fim de determinar a freqüência de bactérias endofíticas de citros produtoras de substâncias inibitórias do tipo bacteriocina (SITB), assim como examinar os efeitos destas SITB sobre a comunidade 
bacteriana de citros e finalmente, tentar entender a interação destes endófitos produtores de SITB $\operatorname{com} X$. fastidiosa.

\subsection{Material e Métodos}

\subsubsection{Bactérias, meios de cultivo e condições de crescimento.}

As bactérias isoladas de plantas de citros (Saudáveis-SR, Sintomáticas para CVC-AR e AF, assintomáticas para CVC-ER e de plantas de tangerinaPR) testadas neste trabalho foram isoladas por Araújo et al. (2002) e estão listadas na Tabela 1. Linhagens utilizadas como indicadoras de SITB foram: Curtobacterium flaccumfaciens (ER1/15, PR2/2 e ER1/6), Pantoea agglomerans (ARB18), Methylobacterium extorquens (AR1.6/2), $\quad M$. mesophilicum (SR1.6/6) e Escherichia coli (K12 Row). Para os testes com os extratos crus, a linhagem de Xylella fastidiosa (Lacava et al., 2004) foi utilizada. As células de $X$. fastidiosa foram crescidas em meio PW agar (Chang et al. 1993) por 25 dias a $28^{\circ} \mathrm{C}$.

Caso não especificado, considera-se que as culturas foram crescidas por 48 horas em $5 \mathrm{ml}$ de meio M3 [por litro: Bacto peptona 4g (Difco); Triptona $1 \mathrm{~g}$ (Difco); Extrato de Malte 2,4g (Difco); Sacarose $10 \mathrm{~g}$ (Sigma); $\mathrm{K}_{2} \mathrm{HPO}_{4} 1,2 \mathrm{~g}$ (Merck); $\mathrm{KH}_{2} \mathrm{PO}_{4} 1 \mathrm{~g}$ (Merck); $\mathrm{MgSO}_{4}$ 0,4g (Merck); Glutamina 0,4g (Fisher) e Histidina 0,2g (Fisher), pH 6,6]. 
Tabela 1. Espécies e linhagens endofíticas de citros usadas no presente trabalho

Espécies bacterianas

Linhagens

endofíticas de citros*

Curtobacterium flaccumfaciens

AF2/5; AF2/7; AR1.4/11; AR1.5/3; AR4/15; AR5.1/6; ER1.4/2; ER1.4/8; ER1.6/4;

ER1/11; ER1/15; ER1/6; ER1/7; ER1/8;

ER4/15; PR1/10; PR1/11; PR1/8; PR2/2;

PR2/3; SR1.6/2; SR1/6; SR1/8; SR1.4/9;

SR2/1; SR2/11; SR3/13; SR3/19; SR3/20;

$\mathrm{SR} 3 / 8$

Methylobacterium extorquens

AR1.6/11; AR1.6/12; SR1.6/1; SR5/4

Methylobacterium fujisawaense

PR5.1/1; PR5/4; PR5/5; SR5/3

Methylobacterium mesophilicum

AR1.6/1; AR1.6/2; AR1.6/4; AR1.6/6; AR3/20; AR4/19; AR5.1/5; AR5.1/6; AR5/1; AR5/4; ER1.4/4; ER1.6/1; ER1.6/2; ER1.6/4; ER1.6/5; ER1/21; ER1/29; ER1/6; ER5/2; ER5/3; PR1/3; PR1.4/10; PR3/5; PR3/10;

PR3/11; PR3/15; SR3/27; SR1.6/11; SR1.6/6; SR1.6/13

Methylobacterium radiotolerans

SR1.4/10; SR1.6/3

Methylobacterium zatmanii

PR3/8; PR3/17; SR 1.6/2; SR 1.6/9

* Todas as bactérias pertencentes à coleção do Laboratório de Genética de Microrganismos "Prof. João Lúcio de Azevedo" 


\subsubsection{Produção de SITB}

O estudo da produção de SITB por bactérias endofíticas de citros foi conduzido utilizando-se o método de sobrecamada de ágar, descrito por Pugsley \& Oudega (1987), com modificações de acordo com Gross \& Vidaver (1990).

Alíquotas de $10 \mu \mathrm{l}$ de uma cultura, crescida por 48 horas foram gotejadas em placas contendo meio sólido; as quais foram incubadas por 48 horas, a $28^{\circ} \mathrm{C}$. Para prevenir o posterior crescimento de células, após as 48 horas, tais placas foram expostas ao vapor de clorofórmio (40 minutos). Em seguida, uma sobrecamada de $5 \mathrm{ml}$ de ágar semi-sólido $(0,75 \%)$, contendo 50 $\mu$ de uma cultura $\left(10^{8} \mathrm{UFC} / \mathrm{ml}\right)$ da bactéria indicadora, foi vertida sobre a placa.

A produção de SITB foi analisada após dois dias de incubação a $28^{\circ} \mathrm{C}$, pela formação de zonas de inibição de crescimento da camada de bactéria indicadora ao redor da colônia da bactéria testada.

A inibição foi definida como a presença de uma zona opaca, nebulosa, difusa ou completamente clara, ao redor da cultura gotejada na placa. Todos os experimentos de produção de SITB foram realizados em triplicata e repetidos por, pelo menos, três vezes. Para realizar os testes de produção de SITB, diferentes bactérias indicadoras foram usadas como descrito anteriormente. 


\subsubsection{Ensaios com SITB}

A fim de testar o efeito da radiação ultravioleta (UV) na produção de SITB, linhagens de C. flaccumfaciens (ER1.4/2, PR1/10 e ER1/11) foram crescidas em meio M3 e após 12 horas, as colônias bacterianas foram expostas à luz UV (300 nm) por 30 segundos, e novamente incubadas por mais 36 horas antes de ser aplicada a sobrecamada. O ensaio para a indução da produção por Mitomicina $C(0,5 \mu \mathrm{g} / \mathrm{ml}$, Sigma) foi realizado, em cultura líquida como descrito por Feldgarden \& Riley (1998). A inativação de SITB por calor foi determinada pela exposição de placas incubadas por 48 horas e tratadas com clorofórmio, em forno a $80{ }^{\circ} \mathrm{C}$, por 15 minutos. Permitiu-se que a placa resfriasse a temperatura ambiente por 30 minutos, antes de ser aplicada a sobrecamada com a bactéria indicadora. A sensibilidade das SITB a enzimas proteolíticas foi testada gotejando-se $50 \mu \mathrm{L}$ de tripsina $(1 \mathrm{mg} / \mathrm{ml}$, Sigma) ou proteinase $\mathrm{K}$ (1 $\mathrm{mg} / \mathrm{ml}$, Sigma) foram próximos a colônias produtoras de SITB, em placas que haviam sido previamente incubadas e tratadas com clorofórmio. Em seguida, uma camada de bactéria indicadora foi aplicada como descrito anteriormente. Em todos os casos, as placas tratadas foram examinadas após dois dias de incubação e as zonas de inibição foram comparadas com o da placa controle. 


\subsubsection{Fatores de interferência na atividade de SITB}

Para determinar a influência de fatores de interferência na atividade de SITB, diferentes meios de cultura e temperatura de incubação foram testados. A fim de se avaliar a composição do meio de cultura, alíquotas de $10 \mu \mathrm{l}$ de culturas de C. flaccumfaciens (ER1.4/2, PR1/10 e ER1/11), crescidas por 48 horas, foram gotejadas em placas contendo os meios M3 ( $\mathrm{pH} 6,6)$, TSA (ágar de soja tríptica Difco $\mathrm{pH} 7,3$ ) e LB (Luria Bertani, Sigma $\mathrm{pH} 7,0$ ), as quais foram incubadas por 48 horas, a $28^{\circ} \mathrm{C}$ ou $20^{\circ} \mathrm{C}$. As colônias foram mortas por vapor de clorofórmio e, em seguida uma camada de bactéria indicadora foi aplicada como anteriormente descrito. $\mathrm{O}$ pH na zona de inibição, em meio inoculado e não-inoculado, foi medido com o auxílio de um microeletrodo (Beckman). O teste para a presença de bacteriófagos em linhagens de C. flaccumfaciens foi realizado como descrito por Turner \& Jordan (1981).

\subsubsection{Preparação do extrato cru das SITB}

Culturas de $300 \mathrm{ml}$ de C. flaccumfaciens (ER1.4/2, PR1/10 e ER1/11) foram crescidas por dois dias e centrifugadas por 10 minutos, a $14.000 \mathrm{~g}$. O sobrenadante remanescente foi então filtrado por filtro de poro $0.22 \mu \mathrm{m}$ (Millipore) e liofilizado por 72 horas. Os liofilizados foram dissolvidos em $2 \mathrm{ml}$ de água destilada esterilizada e estocados a - $20^{\circ} \mathrm{C}$, até o momento do uso. 
Alíquotas de $50 \mu \mathrm{L}$ deste extrato cru foram gotejadas em placas com ágar e uma camada da bactéria indicadora foi aplicada.

\subsubsection{Preparação do extrato cru de Methylobacterium}

O extrato cru da linhagem de $M$. mesophilicum AR5/1, uma bactéria endofítica não produtora de SITB foi obtido após o crescimento deste endófito em meio TSB por 48 horas a $28{ }^{\circ} \mathrm{C}$, da mesma forma como descrito no item anterior.

\subsubsection{Análise estatística}

A análise estatística de dados foi realizada utilizando-se o programa JMP (JMP, 1995). O teste de médias de Tukey-Kramer foi utilizado para comparar as médias utilizando um nível de significância de 95\%.

\subsection{8 Índice de diversidade}

O Índice de diversidade de bactérias produtoras de SITB por hospedeiro de citros foi calculado pelo índice de diversidade de Shannon (Margurran, 1998). Para a realização de tal cálculo foi utilizada a equação $H^{\prime}=-\Sigma$ pi.Inpi, no 
qual pi representa a relação do número indivíduos de cada espécie pelo número total de indivíduos naquele hospedeiro.

\subsection{Resultados}

\subsubsection{Produção de SITB por bactérias endofíticas de citros}

Trinta e cinco das $74(47 \%)$ bactérias endofíticas de citros testadas foram capazes de exibir SITB em meio sólido para pelo menos uma bactéria indicadora. As freqüências de SITB foram mais baixas (37\%) em isolados de $C$. flaccumfaciens do que na população de Methylobacterium (55\%), (Tabela 2). As linhagens de Methylobacterium produtoras de SITB foram incluídas em todos os quatro haplótipos derivados da técnica de DGGE, previamente descritos por Araújo et al. (2002), mostrando uma grande diversidade para estas bactérias produtoras de SITB (Tabela 2). Contudo quando se analisa o índice de diversidade de Shannon para todas as bactérias produtoras dentro de cada hospedeiro de citros (Figura 1) a diversidade apresenta-se maior em plantas saudáveis $(1,242)$ e de tangerina $(1,241)$, seguida de plantas assintomáticas $(0,673)$ e sintomáticas $(0,377)$ para CVC . A freqüência de SITB foi mais alta em populações bacterianas isoladas de plantas assintomáticas (53\%) e de plantas de tangerina, naturalmente resistentes a CVC (69\%), do 
que daquelas provenientes de plantas saudáveis (29\%) ou que apresentavam sintomas de CVC (44\%).

Com exceção de $M$. radiotolerans, a produção de SITB foi observada para todas as espécies de Methylobacterium testadas (Tabela 2). A mais alta freqüência de produção de SITB foi observada para linhagens de Methylobacterium provenientes de plantas de tangerina e de plantas sintomáticas para CVC 73\% e 58\%, respectivamente (Figura 1). Por outro lado, as linhagens de C. flaccumfaciens isoladas de plantas sintomáticas para CVC apresentaram a mais baixa freqüência de produção de SITB (17\%), (Figura 1).

A maior parte das zonas de inibição observadas para as SITB, foi superior a $2 \mathrm{~mm}$ de diâmetro atingindo até $40 \mathrm{~mm}$ a partir das margens da colônia produtora (Dados não mostrados). Os valores de $\mathrm{pH}$, dentro das zonas de inibição foram medidos para 15 bactérias produtoras de SITB e estes variaram entre 6,0 e 7,0. Para estas 15 bactérias produtoras de SITB pesquisadas, nenhuma apresentou qualquer vestígio da presença de bacteriófagos pelo método utlizado (Dados não mostrados). Os dados de $\mathrm{pH}$ e bacteriófago para as linhagens de C. flaccumfaciens (ER1.4/2, PR1/10 e ER1/11) estão disponíveis na Tabela 3. Tais linhagens produzem SITB preferencialmente em meio $\mathrm{M} 3$, a $28^{\circ} \mathrm{C}$ (Tabela 3). 
Tabela 2. Freqüência de bactérias endofíticas de citros produtoras de SITB

\begin{tabular}{|c|c|c|}
\hline Espécies produtoras de SITB & Linhagens & $\begin{array}{c}\text { Haplótipo de } \\
\text { DGGE* }^{*}\end{array}$ \\
\hline \multirow[t]{5}{*}{ Curtobacterium flaccumfaciens } & AR5.1/6; ER1/7; ER1/11; & --- \\
\hline & ER1.4/2; ER1.4/8; PR1/8; & \\
\hline & PR1/10; PR2/3; SR1/6; SR1/8; & \\
\hline & $\mathrm{SR} 2 / 1$ & \\
\hline & $(37 \% n=30)$ & \\
\hline Methylobacterium extorquens & SR1.6/1 & $E$ \\
\hline Methylobacterium fujisawaense & PR5/4; SR5/3 & $\mathrm{F}$ \\
\hline \multirow[t]{7}{*}{ Methylobacterium mesophilicum } & AR4/19; AR5.1/5; AR5/4 ${ }^{\mathrm{nt}}$ & $A$ \\
\hline & AR1.6/1; AR1.6/2; AR1.6/6; & \\
\hline & AR3/20; ER1.4/4 ${ }^{\text {nt. }}$ ER1.6/1; & \\
\hline & ER1.6/2; ER1.6/4; ER1.6/5; & \\
\hline & ER1/6 nt; PR1/3; PR1.4/10; & \\
\hline & PR3/10 nt; PR3/11; PR3/15; & \\
\hline & $\mathrm{SR} 1.6 / 6^{+}$ & \\
\hline \multirow[t]{2}{*}{ Methylobacterium zatmanii } & PR3/8; PR3/17 & B \\
\hline & $\ddagger(55 \% \quad n=44)$ & \\
\hline
\end{tabular}




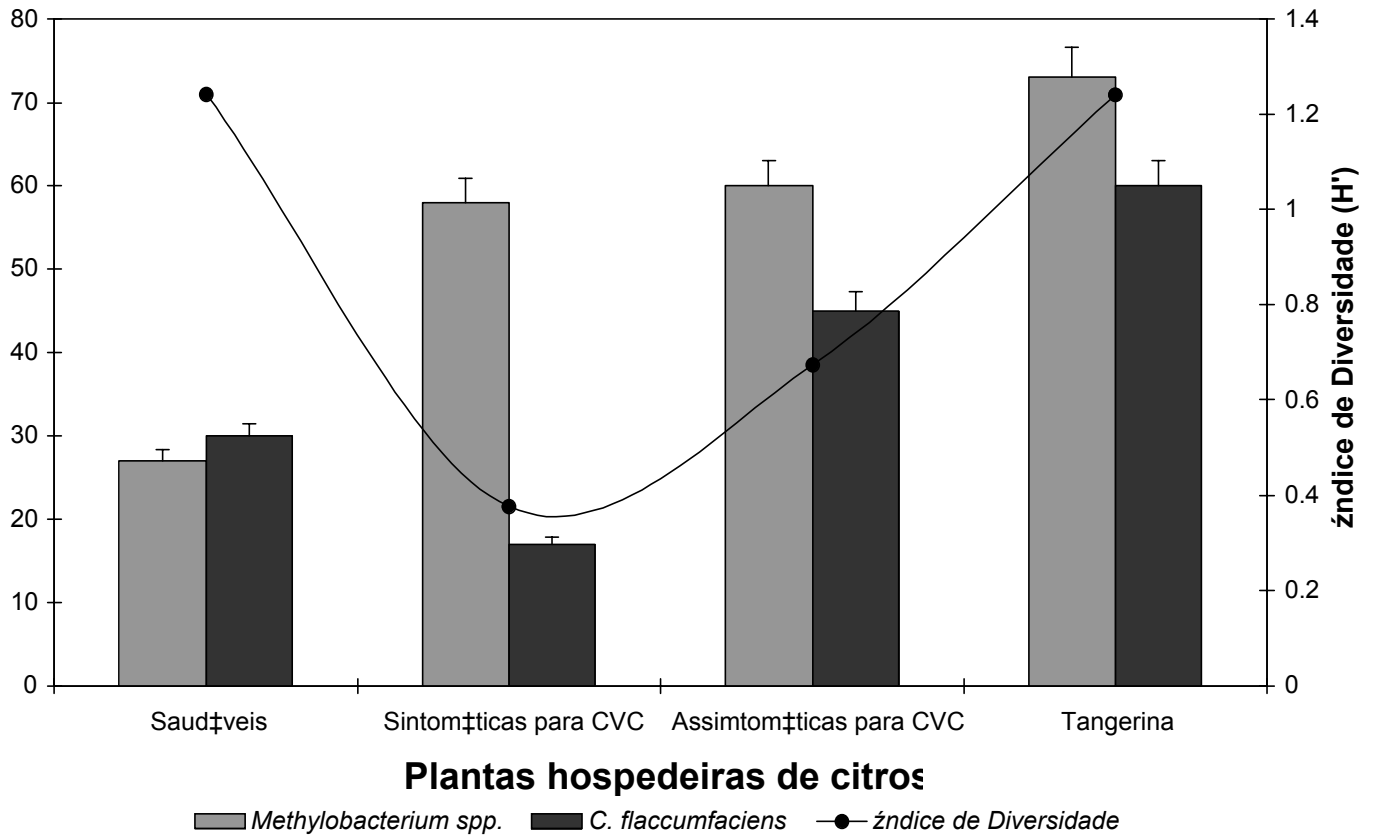

Figura 1 - Freqüência de produção de SITB por bactérias endofíticas de citros. É mostrada freqüência em quatro diferentes plantas hospedeiras de citros para os dois gêneros e o índice de diversidade de Shannon $\left(\mathrm{H}^{\prime}\right)$ de cada grupo de bactérias produtoras num determinado hospedeiro. As barras com a mesma letra não são estatisticamente diferentes, de acordo com o teste de Tukey-Kramer $(P<0.001)$ 
Tabela 3. Fatores de interferência na atividade de SITB por linhagens de $C$. flaccumfaciens

\begin{tabular}{|c|c|c|c|c|c|c|c|c|}
\hline \multirow[t]{3}{*}{ Linhagens } & \multirow{3}{*}{$\begin{array}{c}\text { pH na } \\
\text { zona de } \\
\text { inibição }\end{array}$} & \multirow[t]{3}{*}{ Bacteriófago } & \multicolumn{6}{|c|}{ Meios de cultura* } \\
\hline & & & \multicolumn{2}{|c|}{ M3 } & \multicolumn{2}{|c|}{ TSA } & \multicolumn{2}{|c|}{ LB } \\
\hline & & & $20^{\circ} \mathrm{C}$ & $28^{\circ} \mathrm{C}$ & $20^{\circ} \mathrm{C}$ & $28^{\circ} \mathrm{C}$ & $20^{\circ} \mathrm{C}$ & $28^{\circ} \mathrm{C}$ \\
\hline ER1.4/2 & 6.0 & - & 7 & 8 & - & 1 & - & 1 \\
\hline ER1/11 & 7.0 & - & 12 & 13 & - & 2 & - & 1 \\
\hline PR1/10 & 7.0 & - & 29 & 32 & 3 & 3 & - & - \\
\hline
\end{tabular}

*Média do tamanho das zonas de inibição (mm); - Ausência

\subsubsection{Ação específica das SITB}

Setenta e quatro isolados endofíticos de citros foram avaliados quanto à produção de SITB. Estas bactérias endofíticas inibiram 5 das 7 bactérias indicadoras testadas. Duas das 19 linhagens de $M$. mesophilicum produtoras de SITB (ER1.4/4 e ER1/6) foram capazes de inibir E.coli K12 Row. Somente uma linhagem de C. flaccumfaciens produtora de SITB (AR5.1/6), das onze testadas foi capaz de inibir Methylobacterium spp. (Dados não mostrados). Assim, a maioria das linhagens de $C$. flaccumfaciens produtoras de SITB foram 
efetivas somente contra $C$. flaccumfaciens. Em contraste, isso não foi observado para linhagens de Methylobacterium. De fato todos os 24 isolados de Methylobacterium spp. produtores de SITB inibiram pelo menos uma linhagem indicadora de C. flaccumfaciens (Dados não mostrados). A melhor linhagem indicadora foi C. flaccumfaciens PR2/2 e este foi usado para os demais experimentos. O extrato cru $(50 \mu \mathrm{l})$ de $M$. mesophilicum AR5/1 não interferiu no crescimento em placa tanto de $X$. fastidiosa como de $C$. flaccumfaciens PR2/2 (Dados não mostrados).

\subsubsection{Caracterização de SITB}

Três linhagens de C. flaccumfaciens (ER1.4/2, PR1/10 e ER1/11), que apresentaram maiores zonas de inibição e melhor estabilidade na produção de SITB, foram escolhidas para experimentos posteriores. A atividade destas bactérias foi sensível as enzimas proteolíticas: Tripsina (Dados não mostrados) e proteinase K (Figura 2B). Além disso, a zona de inibição de C. flaccumfaciens (ER1.4/2) foi eliminada por tratamento por calor (Figura 2F). Por outro lado, a exposição da linhagen PR1/10 à luz UV levou a um aumento na zona de inibição em relação ao controle (Figura 2D), entretanto a produção de SITB por estas três bactérias não foi estimulada na presença de Mitomicina C (dados não mostrados). Os sobrenadantes das culturas de C. flaccumfaciens (ER1.4/2, ER 1/11 e PR 1/10, 1/10) foram coletados e concentrados 150 vezes por 
liofilização a fim de obter um extrato cru o qual foi também ativo contra a linhagem indicadora de C. flaccumfaciens PR2/2 (Figura 3), bem como contra X. fastidiosa (dados não mostrados).

Após a realização dos testes com $C$. flaccumfaciens (ER1.4/2, ER 1/11 e PR 1/10), pôde-se concluir que as substâncias antagonistas produzidas por estas bactérias podem ser consideradas bacteriocinas. De acordo com a norma convencional para nomenclatura de bacteriocinas, as bacteriocinas descritas neste trabalho deveriam ser nomeadas de Flaccumfacinas. No entanto, Gross \& Vidaver (1979a e 1979b) nomearam de Flaccumfacinas seis bacteriocinas produzidas por patovares de Corynebacterium flaccumfaciens isolados de Phaseolus vulgaris. A fim de evitar qualquer confusão, as bacteriocinas produzidas por isolados C. flaccumfaciens endofíticos de citros foram denominadas de endoficinas, considerando-se sua origem endofítica. 


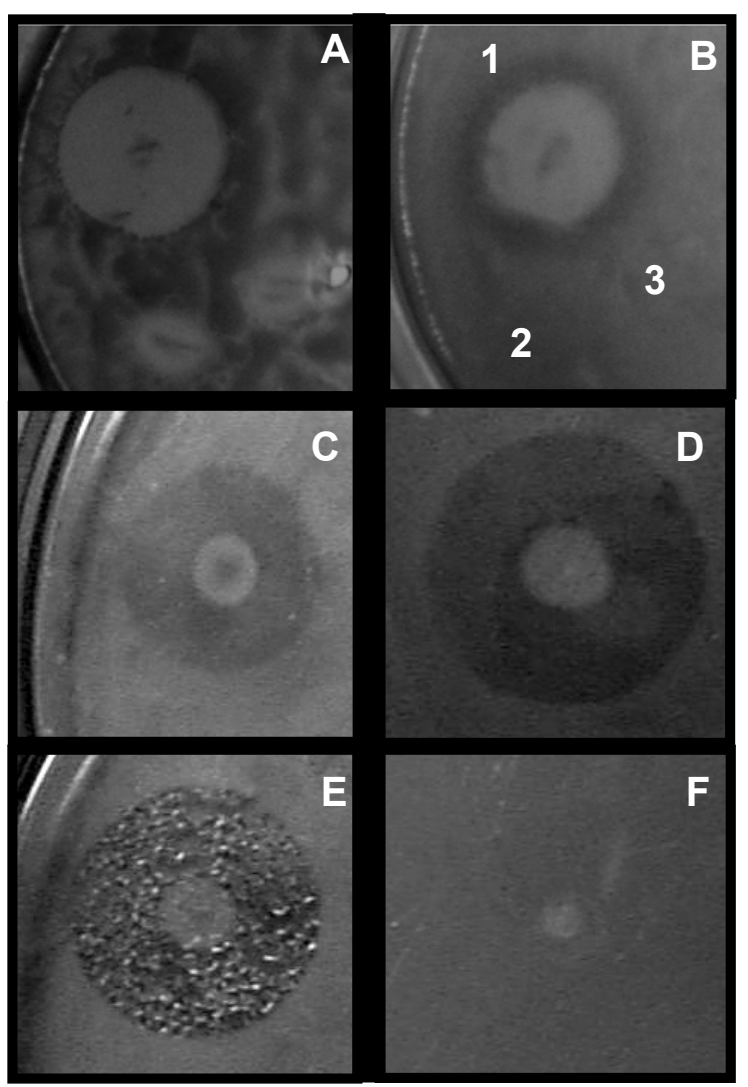

Figura 2 - Inibição do crescimento de C. flaccumfaciens PR2/2 (bactéria indicadora). Uma gota de proteinase $\mathrm{K}(50 \mu \mathrm{l})$ foi colocada próxima à colônia de C. flaccumfaciens (1) PR1/10; (2) ER1/11; (3) ER1.4/2, eliminando a zona de inibição (B). C. flaccumfaciens ER1/11 irradiado com UV exibe zona de inibição aumentada (D). A atividade de bacteriocina não foi observada em placas expostas a $80{ }^{\circ} \mathrm{C}$ por $15 \mathrm{~min}(\mathrm{~F})$. Em A, C e E são mostrados os respectivos controles de B, D e F 


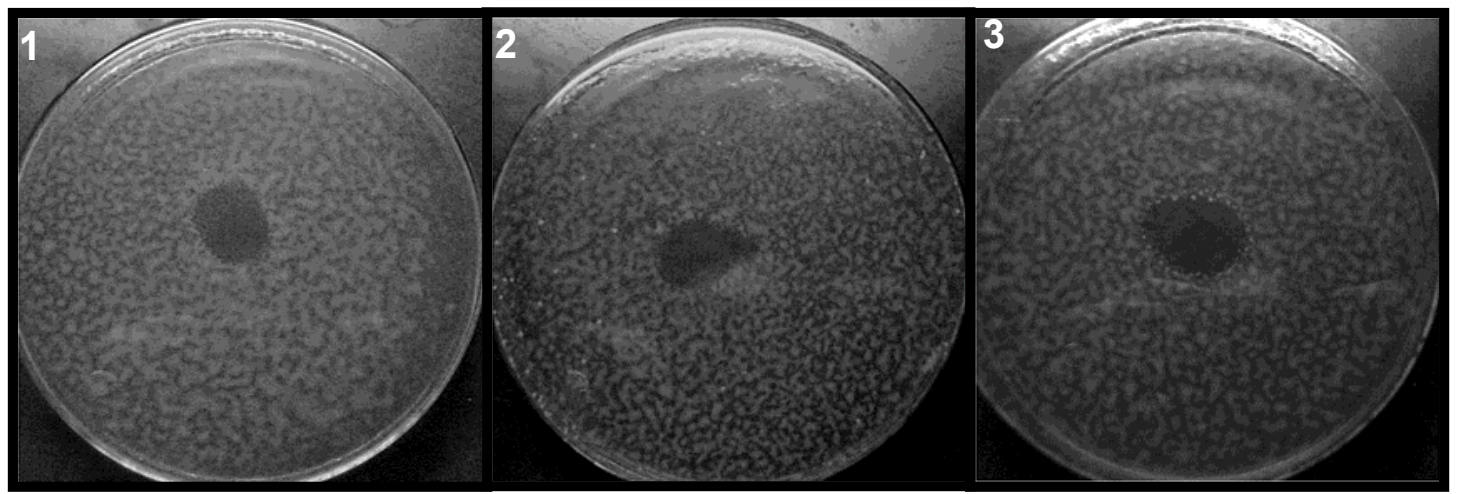

Figura 3 - Efeito de $50 \mu$ do extrato cru das bacteriocinas de C. flaccumfaciens (1) PR1/10 (2) ER1/11 e (3) ER1.4/2 sobre C. flaccumfaciens PR2/2 (bactéria indicadora)

\subsection{Discussão}

As formas mais bem conhecidas de como as bactérias endofíticas podem afetar a saúde das plantas incluem: $i$ ) antagonismo direto ou exclusão do nicho do patógeno, ii) indução de resistência sistêmica e iii) aumento da tolerância da planta a estresse biótico. Além destes efeitos, bactérias endofíticas não exibem qualquer efeito nocivo ao colonizar a planta hospederia. Tais endófitos podem apresentam uma associação neutra com a planta ou permanecem latentes até se tornarem ativos em estágios mais tardios do desenvolvimento do hospedeiro vegetal (Hallmann et al., 1997; Munif et al., 
2001; Seghers et al., 2004). No entanto, ainda não está esclarecido, como as interações dentro da comunidade endofítica podem afetar a saúde das plantas.

Os endófitos, C. flaccumfaciens e Methylobacterium spp. colonizam com sucesso os tecidos do xilema, dividindo o seu nicho ecológico com $X$. fastidiosa. No microambiente do xilema, diferente relação entre a comunidade bacteriana podem ocorrer envolvendo os tipos básicos de interação ecológica, como a competição (dois ou mais organismos competem por recursos ou mesmo defendem-se ativamente um contra o outro) e o mutualismo (um organismo em particular é mais bem sucedido na presença de outro) (Callaway \& Walker 1997).

Bactérias endofíticas produtoras de SITB ocorrem em plantas de citros sintomáticas para CVC. A maior parte dos isolados de Methylobacterium spp. exibiu antagonismo contra linhagens de C. flaccumfaciens, mediado por SITB. Por outro lado, convém ressaltar que somente uma linhagem de $C$. flaccumfaciens, produtora de SITB, foi capaz de inibir Methylobacterium spp; enquanto que todos os 24 isolados de Methylobacterium spp., produtores de SITB, foram capazes de inibir as linhagens de C. flaccumfaciens.

Segundo Araújo et al. (2002), linhagens de C. flaccumfaciens são mais freqüentemente isoladas de plantas assintomáticas do que sintomáticas para CVC. Os resultados obtidos neste trabalho com relação à diversidade de bactérias produtoras de SITB em suas respectivas plantas hospedeiras mostraram que uma baixa diversidade de bactérias (em sua maioria 
Methylobacterium spp.) produzem SITB no hopedeiro sintomático para CVC. Por outro lado, uma diversidade mediana e alta foi encontrada nas plantas assintomáticas para CVC e de tangerina e sintomáticas para CVC, respectivamente. Nestes hospedeiros, com diversidade relativamente alta a produção de SITB ocorre tanto por Methylobacterium spp. quanto por C. flaccumfaciens. Além disso, tem-se sugerido que esta última bactéria poderia inibir o desenvolvimento de $X$. fastidiosa em plantas de citros (Lacava et al., 2004). Assim, a manifestação da patogenicidade de $X$. fastidiosa poderia estar relacionada à drástica redução na freqüência de linhagens de $C$. flaccumfaciens produtores de SITB, associado é claro, a um aumento na população de Methylobacterium spp. quando comparado com a comunidade microbiana de plantas saudáveis de citros.

Por outro lado, em plantas assintomáticas, a patogenicidade de $X$. fastidiosa não é observada, mesmo que seguramente, o patógeno esteja colonizando o hospedeiro. Pequenas populações de plantas assintomáticas têm sido observadas nos pomares; as quais abrem possibilidades para o estudo dos diferentes aspectos relativos às causas da CVC. Tais estudos tornam-se bastante interessantes, uma vez que as plantas assintomáticas apresentam o mesmo genótipo das plantas susceptíveis e ambas se desenvolvem sobre condições climáticas e edáficas semelhantes (Araújo et al., 2002). 
Lacava et al. (2004) mostraram a inibição de $X$. fastidiosa pelo sobrenadante livre de células da linhagem de C. flaccumfaciens (ER1/6). Esta mesma linhagem foi classificada aqui como produtora de SITB.

No presente trabalho, o extrato cru das bacteriocinas de $C$. flaccumfaciens (ER1.4/2, PR1/10 e ER1/11) foi também capaz de inibir $X$. fastidiosa. Nossos dados sugerem que linhagens de C. flaccumfaciens produtoras de SITB poderiam levar a um decréscimo na população de $X$. fastidiosa, reduzindo os sintomas da CVC. Além disso, Araújo et al. (2002) e Lacava et al. (2004) mostraram que espécies de Methylobacterium podem afetar sinergicamente o crescimento de $X$. fastidiosa. Neste trabalho nenhum efeito sinérgico foi observado entre $M$. mesophilicum AR5/1 e $X$. fastidiosa Estes dados, aliados aos descritos neste trabalho representam uma possível evidência da relação mutualística ou neutra entre as espécies de Methylobacterium e $X$. fastidiosa; em contraste com a relação antagônica entre C. flaccumfaciens e $X$. fastidiosa e $C$. flaccumfaciens e espécies de Methylobacterium. Estas últimas interações poderiam ser mediadas pelas endoficinas .

O papel de cada organismo no funcionamento geral de um microambiente, num determinado momento ou situação, deve-se sobretudo à interação mediada por fatores biológicos, neste caso a producão de bacteriocinas. Porém tais organismos contam com um complexo de interações simultâneas com outros que compoem o mesmo micro-ecosistema. Assim, a 
relação social entre eles é indispensável para se entender o funcionamento deste micro-ecosistema como um todo (Crespi, 2001).

É possível caracterizar uma relação ecológica como sendo primariamente mutualística ou antagônica. No entanto, outros organismos podem afetar indiretamente a relação entre dois organismos. Este terceiro organismo pode se tornar então parte integral da maneira como os dois organismos originais interagem, quer seja facilitando e/ou interferindo nesta relação (Callaway \& Walker ,1997). Dessa forma, sugere-se neste trabalho, que as espécies de Methylobacterium, C. flaccumfaciens e X. fastidiosa possam interagir ciclicamente, resultando na presença ou ausência dos sintomas da CVC (Figura 4).

O presente trabalho descreveu pela primeira vez na literatura a produção de SITB por endófitos de citros em ambos os gêneros estudados. Ainda que questões possam permanecer sem resposta tais como, quão essencial é o papel desempenhado por estes endófitos produtores de compostos bioativos na manifestação dos sintomas da CVC, ou mesmo se estas bactérias são capazes de influenciar nos mecanismos de patogenicidade em $X$. fastidiosa, os achados aqui reportados são de grande importância para o estudo da compreensão do papel ecológico de endófitos de plantas superiores em seus hospedeiros. 


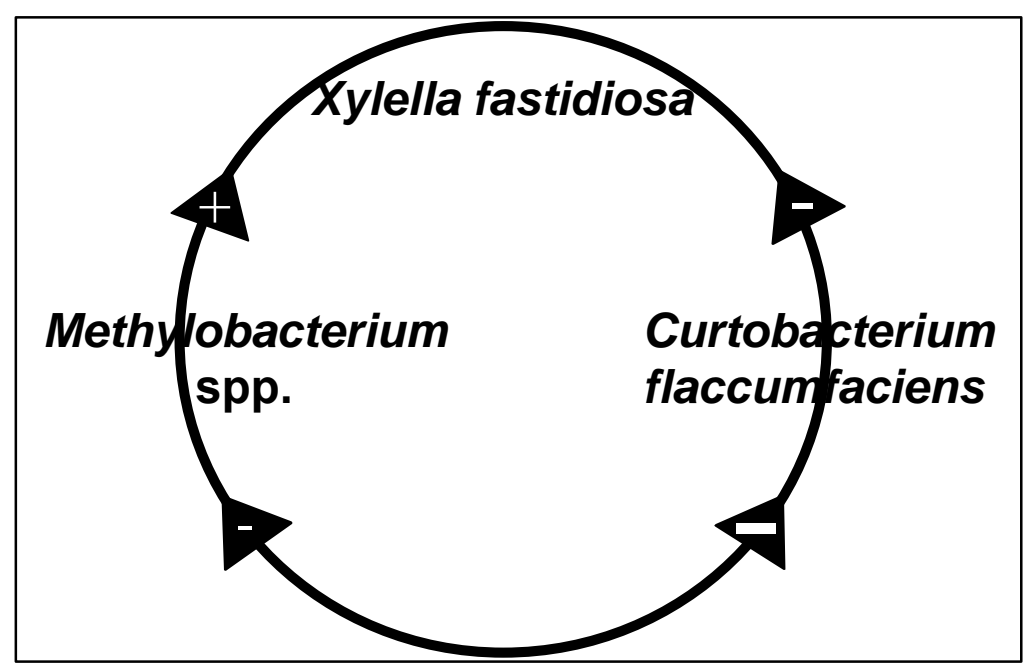

Figura 4 - Modelo proposto para explicar a possível interação entre Xylella fastidiosa, C. flaccumfaciens e Methylobacterium spp. in planta. O desequilíbrio ecológico entre estas espécies poderia resultar nos sintomas da CVC. Interação positiva (+); interação negativa fraca (-); moderada $(-)$ e forte $(\boldsymbol{})$

Acredita-se que o conhecimento da interação entre estas bactérias endofíticas representa um avanço sobre como os aspectos ecológicos da interação planta-microrganismos podem interferir causando e controlando doenças como a CVC. O fato de tais endófitos colonizarem as plantas de citros sugere que estes possam ser utilizados para futuras aplicações, tais como vetores para o envio de bacteriocinas ou de outras enzimas para controle de doenças de citros. 


\subsection{Conclusões}

Com base resultados obtidos pôde-se concluir que:

a) bactérias endofíticas citros (Citrus sinensis e Citrus reticulata) foram capazes de produzir SITB in vitro, sendo que as produtoras de SITB provenientes plantas sintomáticas para CVC exibiram uma menor diversidade.

b) fatores como o meio de cultura e a temperatura de incubação podem influenciar na produção de SITB por bactérias endofíticas de citros;

c) bacteriocinas produzidas pelas linhagens de Curtobacterium flaccumfaciens (PR1/10, ER1/11 e ER1.4/2) puderam ser identificadas e foram designadas endoficinas $A$; $W$ e $L$.

d) a freqüência produção de SITB por bactérias endofíticas em diferentes hospedeiros de citros poderia estar influenciando or mesmo ser resultado da presença em plantas sintomáticas ou ausência de $X$. fastidiosa em plantas assintomáticas e de tangerina. 


\section{CARACTERIZAÇÃO DA ENDOFICINA L, UMA BACTERIOCINA DO ENDÓFITO DE CITROS Curtobacterium flaccumfaciens.}

\section{Resumo}

Endoficina L é uma bacteriocina, produzida por Curtobacterium flaccumfaciens ER1.4/2, uma actinobacteria endofítica isolada de citros. Esta bacteriocina foi parcialmente purificada por cromatografia de interação hidrofóbica, exibindo um peso molecular estimado de de $14 \mathrm{kDa}$ in situ. A endoficina $\mathrm{L}$ atinge seu nível máximo de produção na fase estacionária e é ativa contra bactérias Grampositivas e Gram-negativas, incluindo patógenos humanos e de plantas. Um clone cosmidiano contendo fragmento de $40 \mathrm{~kb}$ da bibioteca genômica de $C$. flaccumfaciens foi selecionado por sua habilidade de inibir a bacteria indicadora in vitro. Este fragmento foi subclonado num vetor plasmidiano. $\mathrm{O}$ seqüenciamento revelou um operon de $2,0 \mathrm{~kb}$ consistindo de pelo menos três genes preditos envolvidos na produção da bacteriocina. Analises in silico sugerem que a endoficina $L$ seja uma bacteriocina do tipo toxina que pode ser uma candidata em potencial como agente no controle biológico de $X$. fastidiosa e outros fitopatógenos. 


\section{Summary}

Endophycin $\mathrm{L}$ is a bacteriocin produced by Curtobacterium flaccumfaciens ER1.4/2, an actinobacterium isolated from citrus branches. The bacteriocin was partially purified by hydrophobic interation chromatography. Endophycin $L$ has a molecular weight estimated of $14 \mathrm{kDa}$ and exhibited in gel activity. Endophycin $\mathrm{L}$ production started at the exponential phase and reached its highest point during the stationary phase. It was capable of inhibiting the growth of Grampositive and Gram-negative bacteria, incluiding several human and plant pathogens. One cosmid clone containing a $40-\mathrm{Kb}$ fragment from a genomic library of C. flaccumfaciens was selected for its ability to consistently inhibit a sensitive indicator strain in plate assays. The fragment was subcloned into a plasmid vector. DNA sequencing revealed an operon consisting of at least three putative genes related to endophycin production. In silico analyses suggested that endophycin $L$ is a toxin-like bacteriocin, this bacteriocin could be a potential candidate as biological control agent against $X$. fastidiosa and other plant pathogens. 


\subsection{Introdução}

Várias bactérias produzem um ou mais peptídeos antimicrobianos ou proteínas as quais são ativas contra outras bactérias, as chamadas bacteriocinas. As bacteriocinas são sintetizadas no ribossomo e enviadas para fora da célula. Estes compostos exibem freqüentemente mecanismos de citotoxicidade bem diversos e distintos (Xie et al., 2004; Breukink et al., 1999) e desempenham um papel na melhora da competitividade das bactérias produtoras contra bactérias que co-habitam o mesmo microambiente (Diep \& Nes, 2002; Maldonado et al., 2004).

É sabido que as bactérias associadas a plantas habitam ambientes altamente competitivos (Parret et al., 2003), e conseqüentemente durante a evolução desenvolveram ferramentas biológicas a fim de competirem por nutriente e nicho ecológico, como a produção de bacteriocinas (Dong et al., 2004; Maldonado et al., 2004). Bactérias fitopatogênicas que incluem os membros dos grupos das Corynebacteria, Erwinia, Pseudomonas, e Xanthomonas são capazes de produzir bacteriocinas (Heu et al., 2001; Parret et al., 2003; Wang et al., 2003; Tudor-Nelson et al., 2003; Kim et al., 2004). Assim tradicionalmente, para bactérias associadas a plantas, a pesquisa de bacteriocinas tem se focado mais freqüentemente em bactérias fitopatogênicas. Só recentemente Pinõn et al. (2002) descreveram a primeira bacteriocina do tipo lisozima produzida por uma bactéria endofítica de cana-de-açúcar. 
Curtobacterium flaccumfaciens é uma bactéria fastidiosa restrita ao xilema que tem sido encontrada como endófito em várias plantas de citros incluindo, laranja doce (Citrus sinensis), tangerina (Citrus reticulata) e limão (Citrus jambhiri) (Araújo et al., 2002; Gardner et al., 1982). Esta bactéria também coloniza a filosfera de amendoim (Jacobs \& Sundim, 2001), ervas daninhas (Vidaver, 1982), beterraba (McQuilken et al., 1993) e trigo (Legard et al., 1994).

A crescente demanda por métodos de proteção as plantas que sejam menos nocivos ao ambiente e seguros do ponto de vista higiênico e alimentar e que sejam de origem biológica, estimulou a pesquisa de bactérias endofíticas de citros em busca de novas agentes antimicrobianos do tipo bacteriocina que poderiam desempenhar um papel no controle biológico de doenças de citros (Foldes et al., 2000; Shoda, 2000).

No capítulo anterior foi descrita uma linhagem de $C$. flaccumfaciens isolada de ramos de Citrus sinensis capaz de produzir uma substância do tipo bacteriocina a qual foi ativa contra um dos mais importantes patógenos de citros Xylella fastidiosa. Neste capítulo, descreveu-se a caracterização da endoficina L de C. flaccumfaciens ER 1.4/2. Foram aqui reportados, o isolamento parcial desta bacteriocina, posterior clonagem, seqüenciamento e identificação de alguns genes que fazem parte do operon da endoficina $L$. 


\subsection{Material e Métodos}

\subsubsection{Linhagens bacterianas e condições de cultivo.}

Os isolados bacterianos e os vetores utilizados neste estudo estão listados na Tabela 1. Quando não especificado a bactéria foi crescida em caldo de soja tríptica - TSB (Difco) a $30^{\circ} \mathrm{C}$. C. flaccumfaciens foi crescida em TSB a $28{ }^{\circ} \mathrm{C}$. Caldo Luria Bertani - LB (Difco) foi utlizado para o crescimento de Escherichia coli a $37^{\circ} \mathrm{C}$. As espécies de Xanthomonas foram crescidas em meio BGE [Caldo Nutriente (Oxoid) acrescido de $2 \mathrm{~g} / \mathrm{L}$ de Glicose (Sigma)] a $30^{\circ} \mathrm{C}$. Espécies de Agrobacterium foram crescidas em Caldo Batata Dextrose (Difco) a $30{ }^{\circ} \mathrm{C}$. Xylella fastidiosa foi crescida em meio PW (Chang et al., 1993) a $28^{\circ} \mathrm{C}$. Os meios foram solidificados com ágar-ágar a 1,5\% (Merck). Quando requerido, ampicilina (Sigma) e/ ou canamicina foram adicionadas a uma concentração de $100 \mu \mathrm{g} / \mathrm{ml}$. 5-Bromo-4-chloro-3-indolil-beta-D-galactopiranosideo (X-Gal) e IPTG (40 mg/ml, Eppendorf) foram adicionados para detectar a presença do inserto de DNA no vetor TOPO pCR4Blunt-TOPO (Invitrogen) clonado em E. coli DH5 $\alpha$. Estoques bacterianos foram mantidos a $-80^{\circ} \mathrm{C}$. 


\section{Tabela 1. Bactérias e vetores usados neste estudo}

\begin{tabular}{|c|c|c|}
\hline Bactérias e vetores & $\begin{array}{l}\text { Genótipo ou característica } \\
\text { relevante }\end{array}$ & $\begin{array}{l}\text { Procedência } \\
\text { ou referência }\end{array}$ \\
\hline \multicolumn{3}{|l|}{ Vetores } \\
\hline SuperCos1 & $\begin{array}{l}\text { Promotor SV40, origem do pUC, sítio Cos, } \\
\text { seqüência de reconhecimento Cos, Amp', } \\
\text { Neo }^{r}\end{array}$ & Stratagene \\
\hline $\begin{array}{l}\text { L3391 Plasmideo } \\
\end{array}$ & SuperCos1 com o operon da endoficina $L$ & Este estudo \\
\hline pCR4bluntTOPO & $\begin{array}{l}\text { Plac, origem do pUC, LacZaccdb, sitio de } \\
\text { clonagem TOPO, Amp }{ }^{r}, \mathrm{Kan}^{r}\end{array}$ & Invitrogen \\
\hline \multicolumn{3}{|l|}{ Bactérias } \\
\hline XL1Blue MR & $\begin{array}{l}\Delta(m c r A) \quad 183 \quad \Delta(m c r C B-h s d S M R-m r r) 173 \\
\text { endA1 supE44 thi-1 recA1 gyrA96 relA1 } \\
\text { lac }\end{array}$ & Stratagene \\
\hline $\mathrm{DH} 5 \alpha$ & $\begin{array}{l}\text { SupE44 } \Delta \text { lac } U 169(\pi \text { 80lacZ } \Delta \text { M15) hsd } \\
R 17 \text { recA1 endA1 gyrA96 thi-1 relA1 }\end{array}$ & $\begin{array}{l}\text { Sambroock } \\
\text { Russel, } 2001\end{array}$ \\
\hline \multicolumn{3}{|l|}{ Espectro de atividade } \\
\hline Escherichia coli ATCC 25922 & Linhagem padrão & FST/Cornell \\
\hline $\begin{array}{l}\text { Escherichia coli BF2 } \\
\text { Listeria ivanovii }\end{array}$ & 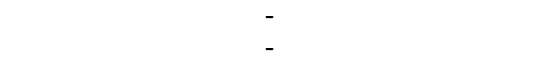 & $\begin{array}{l}\text { Martin et al., } 2003 \\
\text { PP/Cornell }\end{array}$ \\
\hline Listeria monocytogenes F8027 & - & FST/Cornell \\
\hline Erwinia amylovora 96-01 & - & PP/Cornell \\
\hline Erwinia amylovora SW-2 & - & PP/Cornell \\
\hline Erwinia amylovora AC4150 & - & PP/Cornell \\
\hline Erwinia amylovora 0585 & - & PP/Cornell \\
\hline Erwinia herbicola 4288 & - & PP/Cornell \\
\hline Xanthomonas campestris pv. glycines 27 & - & PP/Cornell \\
\hline Agrobacterium tumefasciens C58 & - & PP/Cornell \\
\hline Pseudomonas syringae pv. syringae 37 & - & PP/Cornell \\
\hline Pseudomonas syringae pv. syringae 52 & - & PP/Cornell \\
\hline Clavibacter michiganensis michiganensis $\mathrm{T}$ & Isolada de folhas de tomate & PP/Cornell \\
\hline Clavibacter michiganensis michiganensis $\mathrm{P}$ & Isolada de pimentão. & PP/Cornell \\
\hline Bacillus subtilis ATCC & Linhagem padrão & FST/Cornell \\
\hline Micrococcus luteus & Linhagem padrão & FST/Cornell \\
\hline Staphylococcus aureus ATCC 25923 & Linhagem padrão & FST/Cornell \\
\hline Curtobacterium flaccumfaciens PR2/2 & Indicadora de endoficina L & Capítulo 3 \\
\hline Xylella fastidiosa & Isolada de citros & $\begin{array}{l}\text { Lacava et al., } \\
2004\end{array}$ \\
\hline $\begin{array}{c}\text { Outra } \\
\text { Curtobacterium flaccumfaciens ER1.4/2 }\end{array}$ & Produtora de endoficina $L$ & Este estudo \\
\hline
\end{tabular}

FST/Cornell: Dr. Randy Worobo Food Microbiology Lab., Dept de Ciência dos Alimentos e Tecnologia, NYSAES Cornell University Geneva, N.Y., EUA; PP/Cornell: Dr. Tom Burr Lab., Dept de Fitopatologia NYSAES Cornell University Geneva, N.Y., EUA 


\subsubsection{Espectro de atividade}

O espectro antimicrobiano foi determinado utilizando-se o ensaio de inibição descrito por Ahn \& Stiles (1990). De forma breve, uma gota de $10 \mu \mathrm{L}$ da bactéria produtora foi inoculada em placa contendo meio TSA e incubada por 24 horas a $28{ }^{\circ} \mathrm{C}$. Então, $5 \mathrm{ml}$ de ágar semi-sólido $(0,75 \%)$ do meio ótimo para cada bactéria indicadora foi derretido, e inoculado com $50 \mu \mathrm{l}$ da cultura da bactéria indicadora $\left(\sim 10^{6}\right.$ células viáveis/ml) e então vertido na superfície da placa contendo a colônia da bactéria produtora. Estas placas foram incubadas por 24 horas a 28,30 ou $37^{\circ} \mathrm{C}$ (de acordo com a temperatura ótima da bactéria indicadora), as zonas de inibição foram então determinadas.

\subsubsection{Produção de endoficina $L$ durante o crescimento e definição de unidade arbitrária.}

Dez mililitros de uma cultura fresca de 24 horas da bactéria produtora foi inoculada em $250 \mathrm{ml}$ de TSB e incubada a $28^{\circ} \mathrm{C}$ sob agitação (200 rpm). Durante nove intervalos de tempo durante a incubação, $2 \mathrm{ml}$ da cultura era coletado para se determinar à fase de crescimento e a produção de bacteriocina. Para cada intervalo, $1 \mathrm{ml}$ foi usado para medir a Densidade Óptica a $600 \mathrm{~nm}$ e os outros $1 \mathrm{ml}$ foram imediatamente centrifugados $(14.000 \mathrm{~g}, 1$ minuto, $4^{\circ} \mathrm{C}$ ) para a remoção das células. O sobrenadante foi então tratado por calor a $65{ }^{\circ} \mathrm{C}$ por 20 minutos a fim de se inativar qualquer atividade de 
protease. A atividade de cada sobrenadante foi então determinada utilizando-se o teste de difusão em ágar por diluição de duas vezes.

As amostras foram diluídas serialmente em incrementos de duas vezes e $20 \mu \mathrm{L}$ de cada diluição foram inoculados em placas contendo meio TSA. Após as gotas secarem nas placas, uma sobrecamada da bactéria indicadora era vertida como descrito anteriormente. Uma unidade arbitrária foi definida como $20 \mu \mathrm{l}$ da amostra da mais alta diluição que apresentou uma clara zona de inibição sendo esta, definida para cada intervalo.

\subsubsection{Isolamento parcial da endoficina $L$}

Uma cultura de um litro de $C$. flaccumfaciens ER1.4/2 em meio TSB foi crescida por 24 horas sob agitação $(200 \mathrm{rpm})$ a $28{ }^{\circ} \mathrm{C}$. As células foram removidas por centrifugação (20 minutos, $8.000 \mathrm{~g}, 4{ }^{\circ} \mathrm{C}$ ) e o sobrenadante foi submetido a uma coluna $(2,5 \times 50 \mathrm{~cm})$ contendo $60 \mathrm{~g}$ da resina Amberlita XAD16 (Sigma) sob um fluxo corrente de $3 \mathrm{ml} / \mathrm{min}$ com a ajuda de uma bomba peristáltica. Esta coluna havia sido previamente lavada com $500 \mathrm{ml}$ de Ácido Trifluoro Acético - TFA (Sigma) 0,01\%, 500 ml de Etanol 20\% (Merck) e $500 \mathrm{ml}$ de Etanol 30\%. A bacteriocina foi então removida da coluna de Ambertita pela lavagem com $500 \mathrm{ml}$ de Etanol $45 \%$ e Etanol $80 \%$, ambos contendo $0,01 \%$ de TFA. As frações foram testadas para atividade usando o método de difusão em poços (Jack et al., 1995). A fração ativa em Etanol $45 \%$ foi evaporada utilizando-se o equipamento Rotavapor, e o resíduo amarelo escuro foi então 
redissolvido em $5 \mathrm{ml}$ de água purificada (Milli-Q system, Millipore). Esta solução concentrada foi aplicada numa coluna $(2 \times 50 \mathrm{~cm})$ contendo $30 \mathrm{~g}$ de DEAE Sepharose (Amersham Biosciences) sob um fluxo constante de $1 \mathrm{ml} / \mathrm{min}$. A coluna foi eluída com 0; 0,25; 0,5 e 1M de Cloreto de Sódio (Sigma), e frações de $50 \mathrm{ml}$ foram coletadas. Cada fração foi testada para atividade com descrito anteriormente. A fração ativa de $0,5 \mathrm{M}$ de $\mathrm{NaCl}$ foi então liofilizada e redissolvida em $1 \mathrm{ml}$ de água purificada. Esta fração concentrada foi posteriormente aplicada numa coluna SepPak C18 (Waters), e eluída num gradiente de soluções de 0 a $80 \%$ de Acetonitrila - ACN (Sigma) contendo 0,05\% de TFA. Foram coletadas frações de $5 \mathrm{ml}$. Cada fração foi novamente testada para produção como descrito acima. As frações ativas de ACN 10 e $80 \%$ foram liofilizadas e redissolvidas em $40 \mu \mathrm{l}$ de água purificada para serem submetidas à eletroforese.

\subsubsection{Eletroforese de proteínas.}

O SDS-PAGE ("Sodium Dodecyl Sulfate - Polyacrylamide Gel Electrophoresis") de tricina foi realizado como descrito por Schagger \& von Jagow (1987), utilizando um gel concentrador de poliacrilamida de 10\%, um gel espaçador de $10 \%$ e um gel separador de $16,5 \%$. O padrão de peso molecular utilizado foi o "polypeptide SDS-PAGE molecular weight" (Bio-Rad). A eletroforese foi conduzida em um aparato "Mini-Protean unit" (Bio-Rad) a $150 \mathrm{~V}$ 
por 1 hora. Os géis de poliacrilamida SDS de tricina foram corados com Coomassie blue R-250 (Sigma) a fim de se visualizar as proteínas.

Para a detecção in gel da proteína com atividade de bacteriocina, um gel de SDS-PAGE de tricina foi lavado com água purificada esterilizada por 30 minutos, com três trocas de água sob leve agitação. $O$ excesso de água foi removido com papel absorvente do tipo Kim Wipes $\mathrm{XL}^{\circledR}$ (Kimberly-Clark) e o gel foi transferido para uma placa contendo meio TSA e uma sobrecamada de agar semi-sólido contendo a bactéria indicadora foi aplicada sobre o gel.

\subsubsection{Construção da biblioteca genômica de inserto grande de Curtobacterium flaccumfaciens ER1.4/2.}

A biblioteca genômica de C. flaccumfaciens (ER1.4/2) foi construída usando-se o Kit SuperCos1 (Stratagene) de acordo com as recomendações do fabricante. De uma forma breve, o DNA genômico de C. flaccumfaciens ER1.4/2, foi extraído, purificado e digerido parcialmente com $0,5 \mathrm{U}$ da enzima de restrição Sau3A I (Promega) a $37^{\circ} \mathrm{C}$. Insertos de aproximadamente $40 \mathrm{~Kb}$ foram obtidos, desfosforilados e ligados no vetor SuperCos1, o qual havia sido previamente digerido com as enzimas de restrição Xba I (9 U/mg) e BamH I (5 U/mg) (Promega). O produto da ligação foi encapsidado usando o kit Gigapack Gold Packing Extract (Stratagene) de acordo com as recomendações do fabricante. A biblioteca recombinante foi amplificada por transfecção em células 
competentes de E. coli XL1-Blue MR (Stratagene) as quais foram semeadas em meio LB contendo ampicilina. Os clones obtidos foram isolados e transferidos para placas de microtltulação de 96 poços contendo meio LB acrescido de ampicilina e $10 \%$ de glicerol esterilizado. As placas foram estocadas a $-80^{\circ} \mathrm{C}$

\subsubsection{Varredura da biblioteca genômica para clones produtores de bacteriocina.}

A produção de bacteriocina pelos clones obtidos foi analisada pelo teste de produção por colônias em meio sólido. Gotas das culturas dos clones foram replicadas em placas contendo meio LB suplementado com ampicilina ou não com a ajuda de um replicador manual de 96 pinos (Boekel). As placas foram incubadas por $24 \mathrm{~h}$ a $37^{\circ} \mathrm{C}$. Em seguida, as placas foram tratadas com vapor de clorofórmio e uma sobrecamada de ágar contendo a bactéria indicadora foi aplicada como já descrito anteriormente. Clones que exibiam zonas de inibição claras contra a bactéria indicadora foram selecionados para os próximos experimentos.

\subsubsection{Subclonagem e seqüenciamento.}

Para a subclonagem do clone contendo o operon da endoficina L, o DNA do cosmídeo recombinante de $48 \mathrm{~Kb}$ foi extraído das células de E. coli XL1-Blue MR (previamente crescidas por 18 horas em $1 \mathrm{~L}$ de meio LB a $37^{\circ} \mathrm{C}$ ) utilizando- 
se o kit Qiagen Plasmid Midi Purification (Qiagen), de acordo com o protocolo para cosmídeos de baixíssimo número de cópias fornecido pelo fabricante.

O DNA cosmidial $(1 \mu \mathrm{g})$ foi sonicado uma vez por $25 \mathrm{~s}$ usando-se o aparelho ultrasonic homogenizer (Cole Parmer). O DNA sonicado foi submetido à eletroforese em agarose $1 \%$ e a banda correspondente de aproximadamente $1 \mathrm{~Kb}$ foi cortada e purificada do gel. A Sub-biblioteca foi construída com $100 \mathrm{ng}$ de DNA sonicado. A purificação do gel, o reparo, a desfosforilação, a ligação ao vetor pCR4Blunt-TOPO do referido DNA e a eletrotransformação em células de E. coli, foi realizado utlizando-se o Kit TOPO Shotgun Subcloning (Invitrogen), de acordo com as instruções do fabricante.

Os subclones obtidos foram isolados e transferidos para placas de microtitulação de 96 poços contendo meio LB acrescido de ampicilina e 10\% de glicerol estéril. As placas foram então estocadas a - $80^{\circ} \mathrm{C}$

Para a realização da extração plasmidiana, os clones foram repicados do estoque para placas de 96 poços contendo $1 \mathrm{ml}$ de meio líquido suplementado com Ampicilina e Canamicina. As placas foram então incubadas por 18 horas a $37^{\circ} \mathrm{C}$, sob agitação (150rpm) e a extração plasmidiana foi conduzida de acordo com o protocolo padrão de lise alcalina para placas de 96 poços. 0 seqüenciamento do DNA foi realizado com a auxílio do Kit DYEnamic ET (Amersham) utilizando-se os iniciadores: M13R à jusante (5'CAGGAAACAGCTATGAC-3') ou M13F à montante (5'GTAAAACGACGGCCAG-3'). A reação em cadeia pela polimerase (PCR) foi 
conduzida por 40 ciclos de $1 \mathrm{~min}$ a $95^{\circ} \mathrm{C}$ e $30 \mathrm{~s}$ a $55^{\circ} \mathrm{C}$. O produto da PCR foi precipitado (Acetato de Amônio e Etanol 95\%) e submetido ao seqüenciamento automático em sistema capilar utilizando o equipamento MegaBace 1000 (Molecular Dynamics).

\subsubsection{Montagem da seqüência, anotação e análise das seqüências de DNA e proteína.}

As seqüências obtidas foram verificadas manualmente utilizando se 0 programa Sequencher (Gene Codes - http://www.genecodes.com) e montadas com o auxílio do pacote de programas PHRED/PHRAP/CONSED (Ewing et al., 1998; Ewing \& Green, 1998; Gordon et al., 1998). As seqüências foram analisadas quanto a presença de regiões codificantes utlizando-se o programa GeneMark (Besemer \& Borodovsky, 1999). As prováveis funções das regiões codificantes foram determinadas por comparação com genes já conhecidos do banco de dados GenBank ${ }^{\circledR}$ do National Center for Biotechnology Information (NCBI), usando-se o algoritmo BLASTX (Altschul et al., 1997).

Domínios conservados foram identificados utilizando-se o programa MOTIF SCAN (Falquet et al., 2002). Seqüências de genes foram ainda alinhadas usando-se o programa CLUSTALW (Thompson et al.,1994) a fim de se localizar similaridades. O programa BioEdit (Hall, 1999) foi utilizado para editar as seqüências já alinhadas. 
A seqüência de nucleotídeos anotada, referente ao operon da endoficina $L$ descrito neste trabalho foi submetida ao banco de dados GenBank ${ }^{\circledR}$.

Domínios conservados de proteínas foram detectados utlizando-se o a ferramenta Pfam (http://www.sanger.ac.uk/Software/Pfam/). Os pesos moleculares e os pontos isoelétricos $(\mathrm{pl})$ foram estimados com o auxílio do programa ProtParam (http://us.expasy.org/tools/protparam.html). Os potenciais sítios de clivagem para peptídeos sinal foram preditos por meio do programa SignalP (http://www.cbs.dtu.dk/services/SignalP/).

\subsection{Resultados}

\subsubsection{Espectro de ação de C. flaccumfaciens ER1.4/2}

Após a análise da atividade da bacteriocina C. flaccumfaciens ER1.4/2 contra vários gêneros bacterianos pode-se notar que esta foi capaz de inibir bactérias Gram-positivas, bem como Gram-negativas, incluindo bactérias associadas a plantas como os fitopatógenos: Erwinia amylovora, Erwinia herbicola, Pseudomonas syringae pv. syringae, Xanthomonas campestris pv. glycines, Xylella fastidiosa e Agrobacterium tumefasciens.

O patógeno humano Listeria ivanovii foi também inibido. O completo espectro de ação antibacteriano de C. flaccumfaciens ER1.4/2 está apresentado na Tabela 2. 
C. flaccumfaciens $\mathrm{PR} 2 / 2$ e Listeria ivanovii foram inibidos pela bacteriocina produzida pela colônia de C. flaccumfaciens ER1.4/2, assim como pela endoficina parcialmente purificada (Dados não mostrados).

\subsubsection{Produção da endoficina $L$ durante o crescimento bacteriano}

A cinética da produção de endoficina $L$ durante o crescimento de $C$. flaccumfaciens ER1.4/2 está apresentada na Figura 1. A partir desta figura pode-se notar que a produção de endoficina $L$ inicia-se na fase exponencial de crescimento, atingindo sua máxima produção no início da fase estacionária de crescimento desta bactéria. 
Tabela 2. Espectro antibacteriano da endoficina $\mathrm{L}$ produzida por $C$. flaccumfaciens ER1.4/2

\begin{tabular}{lcc}
\hline \multicolumn{1}{c}{ Bactéria Indicadora } & Inibição do Crescimento \\
\hline Escherichia coli ATCC 25922 & - \\
Escherichia coli BF2 & - \\
Listeria ivanovii & ++ \\
Listeria monocytogenes F8027 & + \\
Erwinia amylovora 96-01 & + \\
Erwinia amylovora SW-2 & + \\
Erwinia amylovora AC4150 & + \\
Erwinia amylovora 0585 & + \\
Erwinia herbicola 4288 & + \\
Xanthomonas campestris pv. glycines 27 & + \\
Agrobacterium tumefasciens C58 & + \\
Pseudomonas syringae pv. syringae 37 & + \\
Pseudomonas syringae pv. syringae 52 & + \\
Clavibacter michiganensis michiganensis T & - \\
Clavibacter michiganensis michiganensis P & - \\
Bacillus subtilis ATCC & + \\
Micrococcus luteus & - \\
Staphylococcus aureus ATCC 25923 & + \\
Curtobacterium flaccumfaciens PR2/2 & - \\
Xylella fastidiosa & + \\
\hline - ausência de inibição; + fraca inibição; ++ inibição mediana; +++ forte inibição
\end{tabular}

- ausência de inibição; + fraca inibição; ++ inibição mediana; +++ forte inibição 


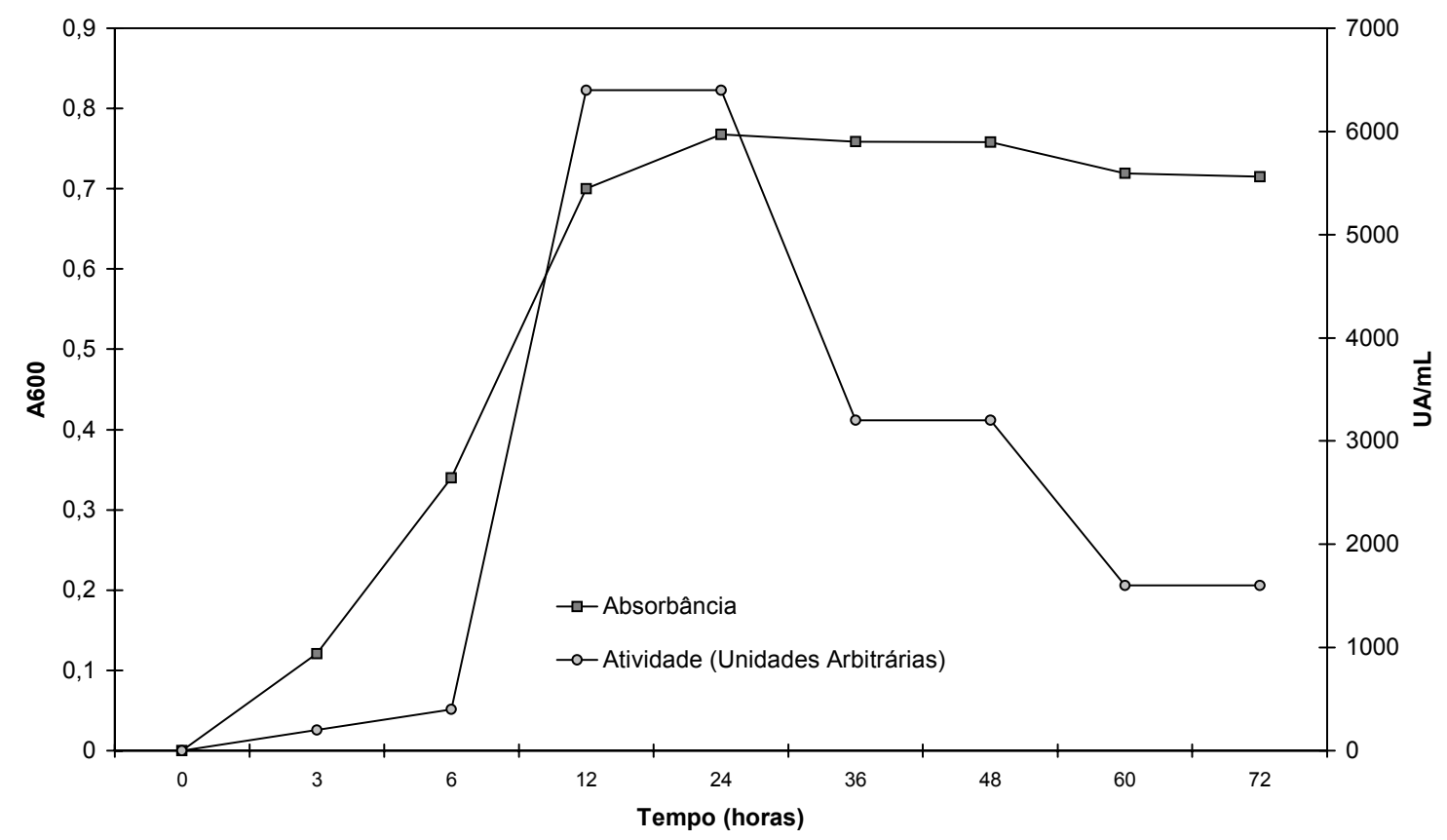

Figura 1 - Produção de endoficina $L$ durante $\mathrm{O}$ crescimento de $C$. flaccumfaciens ER 1.4/2

\subsubsection{Análise bioquímica da endoficina $L$}

Após o isolamento parcial da endoficina $L$, pelo menos seis bandas protéicas foram visíveis em gel de Tricina SDS-PAGE. Dentre estas bandas incluía-se uma de peso molecular aproximado de 14 kDa (Figura 2a, seta). Foi possível ainda detectar a atividade inibitória da endoficina $\mathrm{L}$ in situ após a lavagem e revelação com uma bactéria indicadora de um gel de tricina SDSPAGE não corado. Após este procedimento pode-se observar uma zona de inibição em torno da banda correspondente a 14 kDa (Figura 2b), a qual havia sido previamente observada no gel após coloração. 


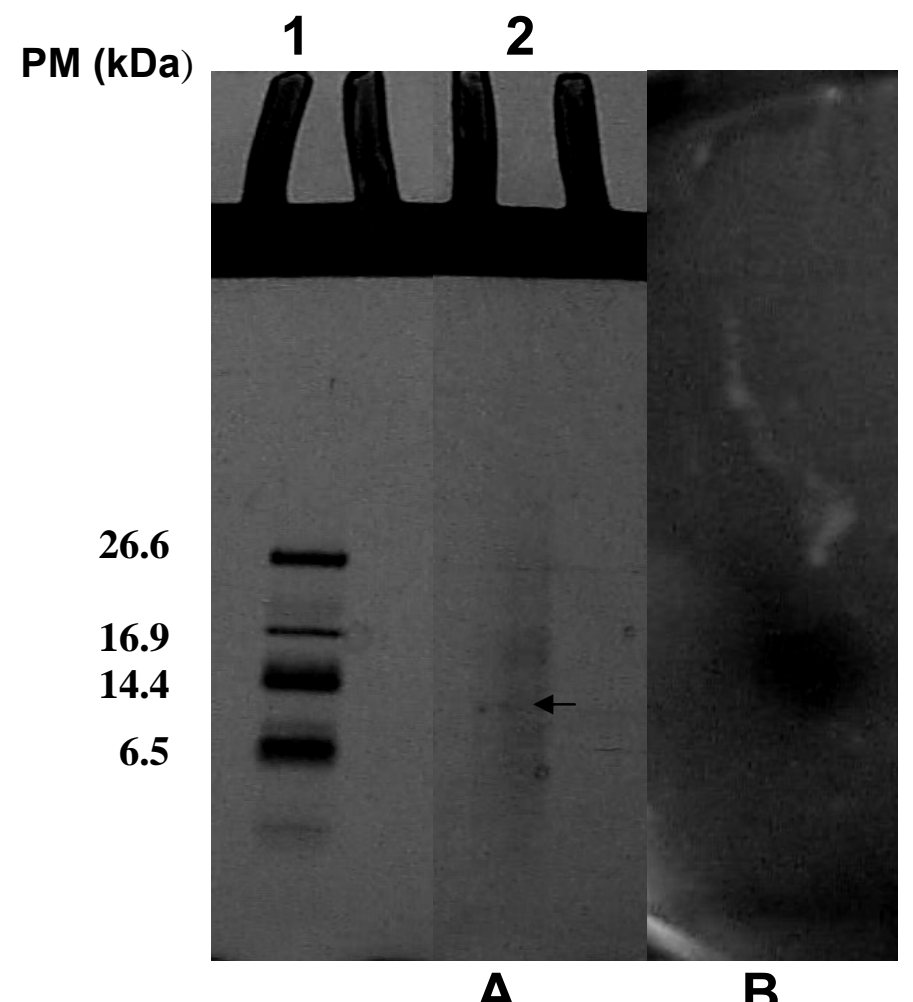

Figura 2 - Análise de tricina SDS-PAGE e detecção direta in gel da atividade da endoficina L. (A) Gel corado com Coomassie blue R 250, Canaleta 1: Peso Molecular; Canaleta 2: endoficina L parcialmente purificada, fração correspondente a 10\% $\mathrm{ACN}$ (B) Gel revelado com bactéria indicadora C. flaccumfaciens PR2/2. A seta indica a banda de $14 \mathrm{kDa}$ com atividade in gel 


\subsubsection{Obtenção da biblioteca genômica de grande inserto e seleção de clones cosmidiais}

A biblioteca genômica do endófito de citros $C$. flaccumfaciens ER1.4/2 foi construída com sucesso sendo obtidos 5534 clones cosmidiais. Assim, esta biblioteca foi capaz de cobrir 74 vezes o genoma de C. flaccumfaciens, considerando-se um genoma de tamanho médio de $2 \mathrm{Mb}$ semelhante aos do grupo das Corynebacterias já seqüenciadas.

Foi então realizada a seleção de clones produtores de endoficina L. Após a análise de 4032 clones, observou-se que quatro destes foram capazes de inibir a bactéria indicadora testada. Um destes clones (L3391) foi escolhido para ser seqüenciado, pois exibiu uma zona de inibição contra a bactéria indicadora C. flaccumfaciens PR2/2 mais clara e evidente, além disso, esta inibição foi completamente abolida na presença de proteinase K (Dados não mostrados).

\subsubsection{Obtenção da sub-biblioteca do clone L3391 e seqüenciamento do cosmídeo}

A sub-biblioteca do clone L3391 foi construída, na qual foram obtidos 384 clones, os quais cobriram 8 vezes o tamanho do clone (48 Kb). Uma amostra de 30 clones foi utlizada para calcular a média de inserto presente na sub-bibioteca por meio da amplificação por PCR utlizando os iniciadores M13F e M13R. A 
média de inserto dos clones analisados variou entre 600 a 1000 pb (Dados não mostrados)

Ao todo, 200 clones foram seqüenciados em duas direções e suas seqüências analisadas para bases de baixa qualidade e preseça de contaminação por sequências de vetor, o que em algumas vezes resultava na remoção integral da seqüência antes da montagem do cosmídeo. A análise para bases de baixa qualidade, seqüências contaminantes, montagem de seqüências contíguas e análise pós-montagem foram realizadas utilizando o pacote de programas PHRED/PHRAP/CONSED. Após a montagem, 38 seqüências contíguas foram obtidas. Ainda que algumas destas seqüências contivessem regiões altamente similares tais seqüências contiguas não se alinharam completamente.

\subsubsection{Anotação funcional do clone L3391}

Até o momento pôde-se anotar uma seqüência de nucleotídeos de $22.684 p b$ do clone L3391. As seqüências de genes preditas foram comparadas com o banco de dados utilizando-se do algoritmo BLASTX (Altschul et al., 1997). Além dos genes necessários a produção e exportação da endoficina $L$, tal seqüência revelou outros genes de interesse em C. flaccumfaciens ER1.4/2, os quais apresentaram em geral, baixa ou nenhuma similaridade com genes já descritos e disponíveis no GenBank ${ }^{\circledR}$. Tais genes podem ser de grande importância no 
estudo desta espécie, uma vez que esta apresenta apenas dois genes descritos. A análise de tais genes foge do escopo deste capítulo, contudo a Tabela 3 apresenta uma pequena fração dos genes hipotéticos de $C$. flacumfaciens presentes no cosmídeo.

Tabela 3. Alguns genes preditos presentes no clone cosmidial L3391 e suas prováveis funções

\begin{tabular}{|c|c|c|c|c|}
\hline Gene & $\begin{array}{c}\text { Tamanho } \\
\text { (pb) }\end{array}$ & BLASTX & $\begin{array}{l}\text { No. de acesso } \\
\text { (organismo) }\end{array}$ & $\mathrm{ID}^{*}$ \\
\hline CF1 & 170 & Prot. ribossômica 50S & $\begin{array}{c}\text { Q6AH25 } \\
\text { (Leifsonia Xyli subesp. Xyli) }\end{array}$ & 91 \\
\hline CF2 & 305 & $\begin{array}{l}\text { Prot. ribossômica 30S } \\
\qquad(\mathrm{rpsN})\end{array}$ & $\begin{array}{c}\text { YP663211 } \\
\text { (Leifsonia Xyli subesp. Xyli) }\end{array}$ & 84 \\
\hline CF3 & 222 & Acetil-xilano-esterase & $\begin{array}{c}\text { gbAAC06115.1 } \\
\text { (Steptomyces lividans) }\end{array}$ & 54 \\
\hline CF4 & 300 & $\begin{array}{c}\text { Fixação de Nitrogênio - } \\
\text { NifL }\end{array}$ & $\begin{array}{c}\text { spP30663 } \\
\text { (Azotobacter vinelandii) }\end{array}$ & 48 \\
\hline CF5 & 173 & $\beta$-lactamase (bla3) & $\begin{array}{c}\text { Q82F11 } \\
\text { (Steptomyces avermitis) }\end{array}$ & 47 \\
\hline CF6 & 308 & Proteína de virulência & $\begin{array}{c}\text { XF3679 } \\
\text { (Xylella fastidiosa) }\end{array}$ & 40 \\
\hline CF7 & 303 & Flagelina & $\begin{array}{c}\text { 06v307 } \\
\text { (Salmonella enterica) }\end{array}$ & 38 \\
\hline CF8 & 267 & $\begin{array}{c}\text { Sistema de secreção do } \\
\text { tipo III }\end{array}$ & $\begin{array}{c}\text { YP068875.1 } \\
\text { (Yersinia pseudotuberculosis) }\end{array}$ & 32 \\
\hline CF9 & 195 & Tioredoxina & $\begin{array}{c}\text { gbAAO28686.1 } \\
\text { (Xylella fastidiosa) }\end{array}$ & 31 \\
\hline CF10 & 383 & Proteína de superfície & Q87DE1 (Xylella fastidiosa) & 21 \\
\hline
\end{tabular}




\subsubsection{Análise predita de genes no operon da endoficina $L$}

Uma vez que clone L3391 exibiu atividade inibitória compatível com a observada com a BLIS de C. flacumfaciens (endoficina L), era de se esperar que este pudesse apresentar genes condizentes com esta função. Para tanto, a fim de se localizar o provável operon carregando os genes da endoficina L, foi realizada uma varredura in silico de modo semelhante ao método descrito por Dirix et al. (2004). Esta metodologia varre genes que apresentam os domínios responsáveis pelo transporte das bacteriocinas (transportador $A B C$ ) e assim localiza os genes de suas bacteriocinas cognatas presentes na mesma seqüência de DNA e que por ventura não tenham sido anotados por darem origem a peptídios pequenos que são automaticamente excluídos dos bancos de dados não redundantes. Baseado nesta análise, foi encontrado dentro da seqüência de aproximadamente $23 \mathrm{~Kb}$ uma região de $1942 \mathrm{pb}$ que contém os genes hipotéticos responsáveis pela síntese, regulação e exportação da endoficina L (Figuras 3 e 4).

A seqüência de aminoácidos dos genes preditos foi comparada com o banco de dados de proteínas Pfam, a fim de se determinar à presença de domínios conservados. Apenas a proteína relativa transportador $A B C$ mostrou identidade $(30 \%)$ com os domínios conservados da família de transportadores de peptídios antimicrobianos disponíveis no referido banco de dados. Esta proteína apresentou $46 \%$ de identidade com o transportador $A B C$ de peptídio antimicrobiano de Pseudomonas putida. (GOG0577). Dessa forma, um dos 
genes responsáveis pelo transportador $A B C$ de $C$. flaccumfaciens possui $546 \mathrm{pb}$ (Figura 3, verde) e produziria uma proteína de 104 aminoácidos. Esta seria uma proteína hidofóbica cujo peso molecular predito é de 10, 6 kDa e pl 11,83.

Já um dos genes responsáveis pela regulação da endoficina $L$ estaria localizado numa região que compreende 476 pb (Figura 3, azul) cujo produto tem 158 aminoácidos. Este produto exibiu $27 \%$ de identidade com a proteína quinase de histidina do sistema regulatório de dois componentes de Streptomyces avermitidis (NP_825382) e 42\% com a proteína quinase de histidina de Streptococcus mutans UA159 (NP_721404.1). A parte estrutural do gene da endoficina $L$ corresponde a 278pb (Figura 3, vermelho) que daria origem a uma proteína de 93 aminoácidos. Esta proteína apresenta identidade com a hemolisina A de Aeromonas hydrophila (gb|AAB81227.1) em 54 resíduos. O alinhamentos dos aminoácidos destas proteínas estão apresentados na Figura 5. A proteína predita apresenta 9,9 kDa, pl 9,04 e mostra conter resíduos hidrofóbicos.

Com base nestas características pode-se supor que esta proteína seja uma das proteínas estruturais da endoficina $L$ de $C$. flaccumfaciens ER1.4/2.

Não foi observado qualquer possível gene que apresentasse similaridade em seu produto predito com os genes de imunidade descritos para bacteriocinas, depositados nos bancos de dados. 
1 ttggaatect egecegatea etegeggagg acetgaaace cagtettett ecegeggggt

61 tegegegtec ttgggttega eggecacega eggegtttac acecgegtgg acecgaageg

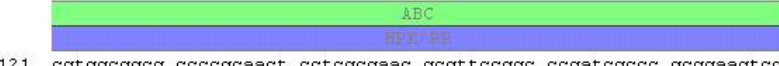
$\triangle B B C$

181 gegtgaeceg tecgtecgac geectegegg cgaagaacge gacggacgac tectteacgg $A B C$

241 getectegte ggeateggeg gggtegecet getggtaggg ggeateggeg tggegaacac

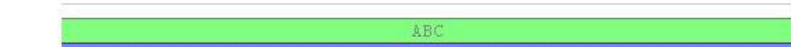

301 gatggtgate acegtecteg aacgecggge egaggtegge gtecgtegeg egeteggtge

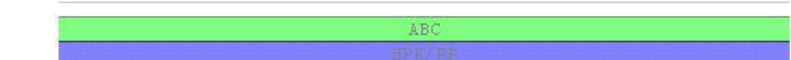

361 ecgtegacgg aacatecgeg accagttect ggtggagteg etettgetgt egttectegg

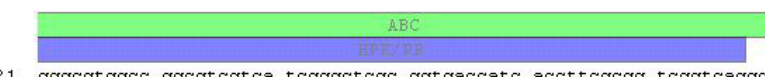

421 gggegtggee ggegtegtea tegggetege ggtgaceate acettegegg teggteaggg ABC

481 etggeeggtg gegateecge tetgggeggt eggtggtgge etegeggega ecgtggtgat $A B C$

541 eggeggegte tecgggetet aceecgetge gegegetgeg egeatecege ceacgtegge $A B C$

601 actggeggee gtetgagegg eggegtgaag ggegaatteg tttaaacetg caggactagt

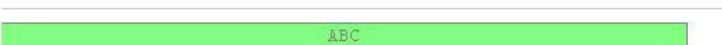

661 cectt $\frac{\text { ggag g gttaattet gagettggeg taateatggt catagetgtt tectgtgtga }}{\text { RBS }}$

721 aatgttatec getcacaatt ceacacaaca tacgagecgg aagcataaag tgtaaagect

781 ggggtgecta atgagtgage taactcacat taatgegtge getcactgee cgetttccag

841 tegggaaace tgtegtgeca getgeattaa tgaateggec aacgegcggg gagaggeggt

01 tgegtatggg egetettecg ettecteget cactgacteg etgegetegg tegttegget 961 geggegageg gtatcagete actcaaagge ggtaatacgg ttatecacag aatcagggat

21 aacgeaggaa agaacatgtg agcaaaagge cageaaagge caggaaccgt aaaaaggecg
1081 egtgetggeg ttecatagge tecgececet gacgageatc acaaatcga egeteagtea

1141 gagtgggaac egacaggaet ataagataca gecgttecec tgaagetcet egtgegetet

1201 eetgttegac etgegttacg gatacetgte egettttece tteggaageg tgggettete

1261 atageteacg etgagtetea gteegggtgg egtegtecag etggetgtgt gegeecectg

1321 cttecectge egtgggetac ggaacategt etggtetece cetagaacga ettteggea

1381 etgtggaggt ccactggtac agggttacac gaccggaggt ttaggegggg getacaaagt

1441 ttgagaaggg ggcgcaaata aggggacaca aaaaaacga ttttgtattt ggeactgaaa

1501 egtactetct gaaaaaagtg tgggtttttc egcgaaaace cececggggt tgggtggggt 1561 tttttggggg tagacaactt aactacegaa aaaaggggtc caaaacatca ttacattacc 1621 ggegaggtac gagetagaga aaacacacgg aggtgtggtg aaccaacaca agceagagta 1681 gaaagagaaa gtagtataca acacaccaat agacagagec agcaagaaac aaaagaggaa 1741 ggaaacgaaa gagacaagca gagatagagg ccacacaaga ccaaggaaga ggagagacac 1801 ccaaaacgge acgaaagcaa cgaagacgac gaaccgacac acaagaaace caacegaaga 1861 gacaaagaga acaacacaac gaagacaaga agaacaaaaa aaagaaaag caaaaaatg 1921 caggaaaaaa agegagegaa aa

\section{Figura 3 - Seqüência de nucleotídeos e correspondente ao operon da endoficina $L$.}

As barras coloridas indicam a proteína quinase de histidina (azul); o transportador $A B C$ (verde) e a proteína estrutural da endoficina $L$ (vermelho) 


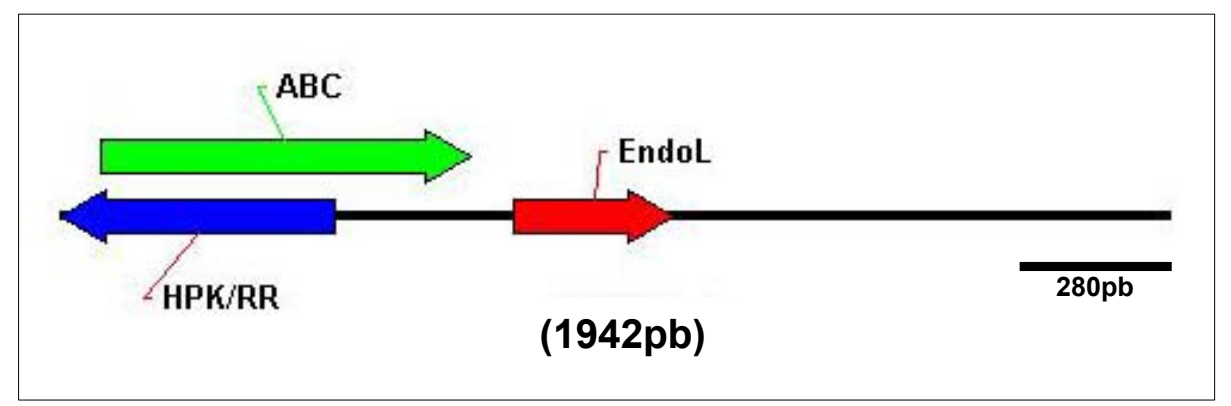

Figura 4 - Representação esquemáticas dos genes preditos do operon da endoficina L. Genes que apresentaram funções prováveis baseados nos resultados da análise por BLASTX. ABC- tranportador ABC; HPK/RRproteina quinase de histidina e endoL- endoficina $L$. As setas indicam a direção da fita codificante

C. flacc: 31 PTRGERRFAYGRSSASSLTDSLRSVVRLRRAVSAHSKAVIRLSTESGDNAGKNM 84 P - - - - - - - SSASSLTDSLRSVVRLRRAVSAHSKAVIRLSTESGDNAGKNM A. hydro: 6 PQMRKEKIPHQPSSASSLTDSLRSVVRLRRAVSAHSKAVIRLSTESGDNAGKNM 59

Figura 5 - Alinhamento da seqüência de aminoácidos da endoficina $L$ de $C$. flacumfaciens e da hemolisina $\mathrm{A}$ de $A$. hydrophila. Alinhamento realizado utlizando o programa CLUSTAL W (Thompson et al., 1994) 


\subsection{Discussão}

Os genes que codificam as bacteriocinas têm sido freqüentemente encontrados em cromossomos e plasmídios bacterianos. Em alguns casos, os conjuntos gênicos que sintetizam as bacteriocinas encontram-se ainda em elementos genéticos móveis, como transposons ou DNA derivado de fago (Diep \& Nes, 2002).

C. flaccumfaciens ER1.4/2 não apresenta qualquer plasmídeo (dados não publicados), sugerindo que o determinante genético da endoficina $L$ possa estar localizado no cromossomo desta bactéria.

Em bactérias Gram-positivas produtoras de bacteriocina é comum observar que a produção destas proteínas seja dependente da fase de crescimento. Freqüentemente, esta produção está restrita do meio ao final da fase exponencial de crescimento até a fase estacionária.

Tem se tornado cada vez mais evidente que a maioria dos produtores de bacteriocinas (em bactérias Gram-positivas) apresentem produção dependente de fase de crescimento. O sistema que controla esta produção é uma rede regulatória de três componentes. Tal sistema é comumente chamado de via de transdução de sinal, responsável por regular a expressão dos genes envolvidos neste processo (Diep \& Nes, 2002).

Acredita-se que em bactérias que utilizam a via de transdução de sinal para regular a produção de bacteriocinas, pequenas quantidades de um fator de indução (IF) sejam secretadas constitutivamente no meio de cultura. Quando 
então certa quantidade limite é atingida, o sinal ou o fator de indução é reconhecido e posteriormente processado por uma proteína quinase de histidina e um regulador de resposta. Estes em última estância acabam por estimular todos os operons no locus da bacteriocina, incluindo o próprio regulador do operon, o IF (Eijsink et al., 2002).

A endoficina $L$ atinge seu nível máximo de produção no início da fase estacionária, o que sugere que sua produção possa também ser controlada por uma rede regulatória de três componentes.

Outros sinais provavelmente semelhantes a IF poderiam ainda induzir a produção da bacteriocina produzida por C. flaccumfaciens ER1.4/2, uma vez que esta bactéria tem sua produção de bacteriocina estimulada na presença de outras bactérias endofíticas dos gêneros Curtobacterium e Methylobacterium (Cursino et al., 2002b). Outros fatores como competição não podem ser descartados neste caso. Segundo Maldonado et al. (2004) a presença de microrganismos competidores têm sido reportada como um fator ambiental que afeta a produção de bacteriocinas.

A endoficina $L$ foi parcialmente purificada utilizando-se várias etapas e após inúmeros esforços. Curiosamente, esta proteína mostrou-se sensível ao tratamento com Sulfato de Amônio (Dados não mostrados), o agente mais freqüentemente utilizado para a precipitação de proteínas do tipo bacteriocina. Yamamoto et al. (2003) observaram que para a enterococina RJ-11 o tratamento com sal de citrato levava a uma agregação desta proteína. Pode-se 
supor que a endoficina $L$ possa agregar-se na presença de Sulfato de Amônio, levando a posterior perda de atividade.

Uma vez que não foi possível através da metodologia empregada a obtenção da seqüência de aminoácidos via purificação proteica, optou-se pela clonagem da endoficina $L$, utlizando com estratégia uma biblioteca genômica de grande inserto a fim de se encontrar os possíveis determinantes genéticos desta bacteriocina e predizer sua seqüencia de aminoácidos. Alguns dos genes responsáveis pela síntese, regulação e exportação da endoficina $L$ foram preditos com base no seqüenciamento do clone cosmidial L3391 que exibia atividade inibitória contra a bactéria indicadora. Pôde-se encontrar uma região de 1942 pb, após o seqüênciamento e varredura in silico, de acordo com Dirix et al. (2004), em busca de genes com função de transporte de peptídios antimicrobianos e suas bacteriocinas cognatas. Nesta região foram preditos três genes, relacionados a endoficina L. Um gene responsável pelo transporte da endoficina L, o qual codifica uma proteína hipotética que faria parte do sistema de exportação da bacteriocina para fora da célula. A regulação da transcrição desta bacteriocina deve ser realizada por pelo menos duas proteínas (a proteína quinase de histidina e o regulador de resposta). É provável, com base nas análises de identidade proteica, que a proteína presente na região de 1.942 pb seja uma proteína quinase de histidina, que seria responsável por fosforilar um fator de transcrição chamado regulador de resposta que ativaria a transcrição dos genes estruturais. 
As bacteriocinas são um grupo muito heterogêneo de compostos antimicrobianos proteicos sintetizados pelo ribossomo (Diep \& Nes, 2002). Devido a essa diversidade de estrutura elas estão inseridas em uma grande família de proteínas secretadas por bactérias Gram-positivas, patogênicas e não-patogênicas, que incluem as bacteriocinas e outras toxinas. (Cintas et al., 1998). Em bactérias Gram-positivas do gênero Enterococcus as toxinas do tipo citolisina exibem uma regulação e modo de ação muito semelhante ao das bacteriocinas da classe II (Coburne \& Gilmore, 2003). A proteina predita de 93 aminoácidos deve fazer parte do gene estrutural da endoficina embora tenha características muito semelhantes a uma toxina. Fato similar foi descrito por Cintas et al. (1998). Estes autores descreveram uma bacteriocina de Enterococcus (enterocina L50) a qual apresentava mais características em comuns a um pequeno grupo de peptídios antimicrobianos e hemolíticos formadores de ( $\delta$-lisinas) que são secretados por bactérias do gênero Staphylococcus, do que com as bacteriocinas da classe II. Estes peptídios eram sintetizados ribossômicamente; não eram modificados pos-tradução; eram secretados sem seqüência líder ou peptídio sinal e não eram co-transcritos com um gene de imunidade. Essas características parecem também ser compartilhadas com a endoficina $L$, ainda que a seqüência de aminoácidos não seja relacionada a esta classe.

Baseando-se na ação in vitro da endoficina $L$, pode-se cogitar que a bacteriocina seja capaz de mediar a interação de $C$. flaccumfaciens com outras 
bactérias residentes no xilema, como $X$. fastidiosa. O papel das bacteriocinas na patogenicidade de $X$. fastidiosa têm sido recentemente discutido. Autores como Pashalidis et al. (2005) e Moreira et al. (2005) são unânimes em afirmar o importante papel da colicina $\mathrm{V}$ - bacteriocina peptídica com ação na membrana, transportada pelo sistema ABC (Gehard et al, 2005) - de X. fastidiosa em condições de patogenicidade. Moreira et al. (2005) sugerem que talvez a bacteriocina de $X$ fastidiosa possa aumentar suas possibilidades de sobrevivência num xilema rico em bactérias endofíticas como descrito por Araujo et al. (2002) e Lacava et al. (2004). Enquanto que Pashalidis et al. (2005) acreditam que a presença de genes funcionais de colicina $\mathrm{V}$ em $X$. fastidiosa poderia evitar a competição com outras bactérias endofíticas na planta, bem como no interior do inseto vetor. Além disso, X. fastidiosa apresenta um sistema de transporte $A B C$ do tipo permease, chamado de sistema Opp que é ubíquo a bactérias Gram-negativas (Moreira et al., 2005). Este sistema importa em geral peptídios com propósitos nutricionais. Contudo, segundo Dirix et al. (2004) é provável que, sendo este um sistema transportador do tipo $\mathrm{ABC}$ pode, de acordo com a concentração e a afinidade aos receptores, importar peptídios catiônicos como as bacteriocinas. Assim, uma vez dentro da célula, a endoficina $L$ poderia levar a morte das bactérias sensíveis possivemente por pela formação de poros na membrana. Obviamente questões sobre o mecanismo de ação da endoficina $L$ e quais outros genes estariam envolvidos no processo ainda permanecem. Entretanto, a ação da endoficina L sobre importantes patógenos e fitopatógenos como Listeria, Xanthomonas, 
Pseudomonas e $X$. fastidiosa denota a importância da continuidade do estudo desta bacteriocina que representa um candidato em potencial como agente no controle biológico não só da CVC, como de outras doenças de importância agronômica.

\subsection{Conclusões}

Com base resultados obtidos pôde-se concluir que:

a) a endoficina L é uma bactericiona produzida por C. flaccumfaciens ER1.4/2 que é ativa contra patógenos humanos e de plantas;

b) a produção da endoficina $L$ inicia-se na fase exponencial de crescimento e atinge seu ponto máximo na fase estacionária;

b) a endoficina $L$ parcialmente purificada que exibe atividade in gel, possui um peso molecular estimado de $14 \mathrm{kDa}$;

c) o operon da bacteriocina apresenta pelo menos três genes hipotéticos relacionados síntese, transporte e regulação da endoficina L;

d) a partir de genes preditos no operon da bacteriocina sugere-se que a endoficina $L$ seja do tipo toxina. 


\section{CONCLUSÕES GERAIS}

a) Bactérias endofíticas citros (Citrus sinensis e Citrus reticulata) foram capazes de produzir SITB in vitro, sendo que as produtoras de SITB provenientes plantas sintomáticas para CVC exibiram uma menor diversidade;

b) fatores como o meio de cultura e a temperatura de incubação podem influenciar na produção de SITB por bactérias endofíticas de citros;

c) bacteriocinas produzidas pelas linhagens de Curtobacterium flaccumfaciens (PR1/10, ER1/11 e ER1.4/2) puderam ser identificadas e foram designadas endoficinas $A$; $W$ e $L$;

d) a freqüência produção de SITB por bactérias endofíticas em diferentes hospedeiros de citros poderia estar influenciando or mesmo ser resultado da presença em plantas sintomáticas ou ausência de $X$. fastidiosa em plantas assintomáticas e de tangerina;

e) a endoficina L é uma bactericiona produzida por C. flaccumfaciens ER1.4/2 que é ativa contra patógenos humanos e de plantas; 
f) a produção da endoficina $L$ inicia-se na fase exponencial de crescimento e atinge seu ponto máximo na fase estacionária;

g) a endoficina $L$ parcialmente purificada que exibe atividade in gel, possui um peso molecular estimado de $14 \mathrm{kDa}$;

h) o operon da bacteriocina apresenta pelo menos três genes hipotéticos relacionados síntese, transporte e regulação da endoficina $L$;

i) a partir de genes preditos no operon da bacteriocina sugere-se que a endoficina $L$ seja do tipo toxina. 


\section{REFERÊNCIAS BIBLIOGRÁFICAS}

ABREHEM, K.; ZAMIRI, I. Purification and characterization of a Corynebacterium ulcerans bacteriocin. Journal of General Microbiology, v.11, p.707-713, 1985.

ALVES, E. Xylella fastidiosa: Adesão e colonização em vasos do xilema de laranjeira doce, cafeeiro, ameixeira, fumo e espécies de cigarrinhas vetoras e formação de biofilme sobre película de poliestireno. Piracicaba 2003. 146p. Tese (Doutorado) - Escola Superior de Agricultura "Luiz de Queiroz", Universidade de São Paulo.

AHN, C.; STILES, M. E. Antibacterial activity of lactic acid bacteria isolated from vacuum-packaged meats. Journal of Applied Bacteriology, v. 69, p.302310, 1990.

ARAÚJO, W. L. A comunidade bacteriana endofítica de citros e sua interação com Xylella fastidiosa, agente causal da Clorose Variegada dos Citros (CVC). Piracicaba, 2000. 131p. Tese (Doutorado) - Escola Superior de Agricultura "Luiz de Queiroz" - Universidade de São Paulo. 
ARAÚJO, W.L.; SARIDAKIS, H. O.; BARROSO, P. A. V.; AGUILAR-VILDOSO, C. I.; AZEVEDO, J. L. Variability and interactions between endophytic bacteria and fungi isolated from leaf tissues of citrus rootstocks. Canadian Journal of Microbiology, v.47, p.229-236, 2001.

ARAÚJO, W.L.; MARCON, J.; MACCHERONI JUNIOR, W.; VAN ELSAS, J.D.; VAN VUURDE, J.W.L.; AZEVEDO, J.L. Diversity of endophytic bacterial populations and their interaction with Xylella fastidiosa in citrus plants. Applied and Environmental Microbiology, v.68, p.4906-4914, 2002.

ALTSCHUL, S. F.; MADDEN, T. L.; SCHAFFER, A. A.; ZHANG, J.; ZHANG, Z.; MILLER, W.; LIPMAN, D. J. Gapped BLAST and PSI-BLAST: a new generation of protein database search programs. Nucleic Acids Research, v.25, p.3389-3402, 1997.

AZEVEDO, J.L.; MACCHERONI JUNIOR, W.; PEREIRA, J.O.; ARAÚJO, W.L. Endophytic microorganisms: a review on insect control and recent advances on tropical plants. Electronic Journal of Biotechnology, v.3, p.40-65, 2000.

BACON, C. W.; WHITE JUNIOR, J. F . Microbial endophytes. New York: Marcel Dekker, 2000, 487p.

BALAKRISHNAN, M.; SIMMONDS, R. S.; TAGG, J. R. Diverse activity spectra of bacteriocin-like inhibitory substances having activity against mutans streptococci. Caries Research, v.35, p.75-80, 2001.

BARK, K.; KÄMPFER, P.; SPONNER, A.; DOTT, W. Polyphosphate-dependent enzymes in some coryneform bacteria isolated from sewage sludge. FEMS Microbiology Letters, v.107, p.133-138, 1993. 
BARKA, E. A.; GOGNIES, S.; NOWAK, J.; AUDRAN, J. C.; BELARBIB, A. Inhibitory effect of endophyte bacteria on Botrytis cinerea and its influence to promote the grapevine growth. Biological Control, v.24, p.135-142, 2002.

BEHRENDT, U.; ULRICH, A.;SCHUMANN, P.; NAUMANN, D.; SUZUKI, K. Diversity of grass-associated Microbacteriaceae isolated from the phyllosphere and litter layer after mulching the sward; polyphasic characterization of Subtercola pratensis sp. nov., Curtobacterium herbarum sp. nov. and Plantibacter flavus gen. nov., sp. nov. International Journal of Systematic and Evolutionary Microbiology, v.52, p.1441-1454, 2002.

BERG, G.; KRECHEL, A.; DITZ, M.; SIKORA, R. A.; ULRICH, A.; HALLMANN, $J$. Endophytic and ectophytic potato-associated bacterial communities differ in structure and antagonistic function against plant pathogenic fungi. FEMS Microbiology Ecology, v. 51, p215-229, 2005.

BESEMER, J.; BORODOVSKY, M. Heuristic approach to deriving models for gene finding. Nucleic Acids Research, v.27, p.3911-3920,1999.

BRENNER, D.J. Gram-negative bacteria of general, medical, and industrial importance. In: KRIEG, N. R.; HOLT, J. G. (Ed.), Bergey's manual of systematic bacteriology, Baltimore :Williams \& Wilkins, 1984, p.408-420.

BREUKINK, E.; WIEDEMANN, I.; VAN KRAAIJ, C.; KRUIPERS,O. P.; SAHL, H. G.; DE KRUIJ, F.F. Use of cell wall precursor lipid II by a pore-forming peptide antibiotic. Science, v. 286, p.2361-2364,1999.

BRLANSKY, R. H.; HARTUNG J. S. Transmission of the Citrus Variegated Chlorosis Bacterium Xylella fastidiosa with the Sharpshooter Oncometopia nigricans. Plant Disease, v.86, p.1237-1239, 2002. 
BRLANSKY, R. H.; DAMSTEEGT, V. D.; HARTUNG, J. S. Transmission of the citrus variegated chlorosis bacterium Xylella fastidiosa with the sharpshooter Oncometopia nigricans. Plant Disease, v. 86, p.1237-1239, 2002.

BURGE, C.; KARLIN, S. Prediction of complete gene structure in human genomic DNA. Journal of Molecular Biology, v.268, p.78-94,1997.

CALLAWAY, R. M.; WALKER, L. R. Competition and facilitation: a synthetic approach to interaction in plant communities. Ecology, v.78, p.1958-1965, 1997.

CAVAGLIERI, L. R.; PASSONE, A.; ETCHEVERRY, M. G. Correlation between screening procedures to select root endophytes for biological control of Fusarium verticillioides in Zea mays L. Biological Control, v.31, p. 259$267,2004$.

CESCONETTO, A. As novas perspectivas para a citicultura brasileira. Revista Online da Federação da Agricultura e Pecuária do Mato Grosso do Sul - FAMASUL, http:// www.famasul.com.br/artigos/visualizar.php?pcodigo=18 (3 ago. 2004)

CHANG, C. J.; GARNIER, M.; ZREIK, L.; ROSSETTI, V.; BOVE, J. M. Culture and serological detection of the xylem-limited bacterium causing citrus variegated chlorosis and its identification as a strain of Xylella fastidiosa. Current Microbiology, v.27, p.137-142,1993.

CHANWAY, C. P. Bacterial endophytes: ecological and practical implications. Sydowia, v.50, p.149-170, 1998. 
CHARNEY, W. Transformation of sterols by Corynebacteriacea. Journal of Applied Bacteriology, v. 29, p.93-106, 1966.

CHEN, J.; CIVEROLO, E. L.; JARRET, R. L.; VAN SLUYS, M-A, OLIVEIRA, M.C. Genetic discovery in Xylella fastidiosa through sequence analysis of selected randomly amplified polymorphic DNAs. Current Microbiology, v. 50, p.78-83, 2005.

CHEN,Y. F.; GUO, J. H.; GUO, Y.H.; ZHANG ,X. M.;GE,Y. Y. Curtobacterium flaccumfaciens pv. beticola pv. nov., a new pathovar of pathogen on sugar beet. Não publicado Submetido (04-10-2003) Seqüência de acesso no banco de dados Genbank ${ }^{\circledR}$ número AY273208.

CHERIF, A.; CHEHIMI, S.; LIMEM, F.; HANSEN, B.M.; HENDRIKSEN, N.B.; DAFFONCHIO, D.; BOUDABOUS, A. Detection and characterization of the novel bacteriocin entomocin 9, and safety evaluation of its producer, Bacillus thuringiensis ssp. entomocidus HD9. Journal of Applied Microbiology, v.95, p.990-1000, 2003.

CHUANG, D.Y.; KYEREMEH, A.G.; GUNJI, Y.; TAKAHARA, Y.; EHARA, Y.; KIKUMOTO, T. Identification and cloning of an Erwinia carotovora subsp. carotovora bacteriocin regulator gene by insertional mutagenesis. Journal of Bacteriology, v.181, p.1953-1957, 1999.

CINTAS, L. M.; CASAUS, P.; HOLO, H.; HERNANDEZ, P.E.; NES, I.F.; HÅVARSTEIN, L. S. Enterocins L50A and L50B, two novel bacteriocins from Enterococcus faecium L50, are related to Staphylococcal hemolysins. Journal of Bacteriology, v.180, p.1988-1994, 1998. 
CLEVELAND, J.; MONTVILE, T.J.; NES, I.F.; CHIKINDAS, M.L. Bacteriocins: safe, natural antimicrobials for food preservation International Journal of Food Microbiology, v. 21, p.1-29, 2001.

COLLINS, M.D.; JONES, D. Reclassification of Corynebacterium flaccumfaciens, Corynebacterium betae, Corynebacterium oortii and Corynebacterium poinsettiae in the genus Curtobacterium, as Curtobacterium flaccumfaciens comb. nov. Journal of General Microbiology, v. 129, p.3545-3548, 1983.

COOMBS, J. T.; MICHELSEN, P. P.; FRANCO, M. M. C. Evaluation of endophytic actinobacteria as antagonists of Gaeumannomyces graminis var. tritici in wheat. Biological Control, v.29, p. 359-366, 2004.

COSTERTON, J. W.; IRVIN, R. T. The bacterial glycocalyx in nature and disease. Annual Review of Microbiology, v.35, p.299-324, 1981.

COBURN, P. S.; GILMORE, M.S. The Enterococcus faecalis cytolysin: a novel toxin active against eukaryotic and prokaryotic cells. Cellular Microbiology, v.5, p. 661-669, 2003.

CRESPI, B. J. The evolution of social behavior in microorganisms. TRENDS in Ecology \& Evolution, v.16, p. 178-183, 2001.

CURSINO, L.; SMARDA, J.; CHARTONE-SOUZA, E.; NASCIMENTO, A.M.A. Recent updated aspects of colicins of Enterobacteriaceae. Brazilian Journal of Microbiology, v.33, p.187-197, 2002a. 
CURSINO, L.; ARAÚJO, W.L; CHARTONE-SOUZA, E.; NASCIMENTO, A.M.A.; AZEVEDO, J.L. Bacteriocins by citrus endophytic bacteria are induced by competition. (compact disc) In: CONGRESSO NACIONAL DE GENÉTICA, 48, Águas de Lindóia, 2002. Resumos : trabalhos. Ribeirão Preto: SBG, 2002b.

DE SOUZA, A. A.; TAKITA, M. A.; COLETTA-FILHO, H.D.; CALDANA, C.; GOLDMAN, G.H.; YANAI, G.M.; MUTO, N.H.; DE OLIVEIRA, R.C.; NUNES, L.R.; MACHADO, M.A. Analysis of gene expression in two growth states of Xylella fastidiosa and its relationship with pathogenicity. Molecular PlantMicrobe Interactions, v.16, p.867-875, 2003.

DIEP, D. B.; NES, I. F. Ribossomally synthesized antibacterial peptides in Gram- positive bacteria. Current Drug Targets, v.3, p.107-122, 2002.

DIRIX, G.; MONSIEURS, P.; DOMBRECHT, B.; DANIELS, R.; MARCHAL, K.; VANDERLEYDEN, J.; MICHIELS, J. Peptide sinal molecules and bacteriocins in Gram-negative bacteria: a genome wide in silico screening for peptides containing a double-glycine leader sequence and their cognate transporters. Peptides, v.25, p.1425-1440, 2004.

DONG, Y. H.; ZHANG, X. F.; XU, J. L.; ZHANG, L. H. Insecticidal Bacillus thuringiensis silences Erwinia carotovora virulence by a new form of microbial antagonism, signal interference. Applied and Environmental Microbiology, v.70, p.954-960, 2004.

DÖPFER, H.; STACKEBRANDT, E.; FIEDLER, F. Nucleic acid hybridization studies on Microbacterium, Curtobacterium, Agromyces and related taxa. Journal of General Microbiology, v.128, p.1697-1708, 1982. 
DWORKIN, M. (Ed.) The Prokaryotes: an evolving electronic resource for the microbiological community. 3.ed. New York: Springer-Verlag, 2003, 1125p.

DYE, D. W.; BRADBURY, J. F.; GOTO, M.;HAYWARD, A. C.; LELLIOTT, R. A.; SCHROTH, M. N. International standards for naming pathovars of phytopathogenic bacteria and a list of pathovar names and pathotype strains. Review of Plant Pathology, v.59, p.153-168, 1980.

EIJSINK, V. G. H.; AXELSSON, L.; DIEP, D. B.; HAVARSTEIN, L. S.; HOLO, H.; NES, I. F. Production of class II bacteriocins by lactic acid bacteria; an example of biological warfare and communication Antonie van Leeuwenhoek, v.81, p.639-654, 2002.

ELBELTAGY, A. K.; NISHIOKA, H.; SUZUKO, T.; SATO, Y.; SATO, H.; MORISAKI, H.; MISTUI, A.; MINAMISAWA, K. Isolation and characterization of endophytic bacteria from wild and traditionaly cultivated rice varieties. Soil Science in Plant Nutrition, v. 46, p.617-629, 2000.

ENNAHAR, S.; SASHIHARA, T.; SONOMOTO, K.; ISHIZAKI, A. Class Ila bacteriocins: biosynthesis, structure, and activity. FEMS Microbiology Reviews, v. 24, p.85-106, 2000.

ERASO, A. J.; INÉS, A. Bacteriocin from lactoserum able to cause oxidative stress in Staphylococcus aureus. Biochemical and Biophysical Research Communications, v. 314, p. 897-901, 2004.

EWING, B.; GREEN, P. Base calling of automated sequencer traces using Phred. II error probabilities. Genome Research,v. 8, p.186-194, 1998. 
EWING, B.; HILLIER, L.; WENDL, M.; GREEN, P. Base calling of automated sequencer traces using Phred. I accuracy assessment. Genome Research, v.8, p.175-185,1998.

EVTUSHENKO, L. I.; TAKEUCHI, M. The Family Microbacteriaceae. In: DWORKIN, M. (Ed.) The Prokaryotes: an evolving electronic resource for the microbiological community. 3.ed. New York: Springer-Verlag, 2003, $1125 p$.

FALQUET, L.; PAGNI, M.; BUCHER, P.; HULO, N.; SIGRIST, C. J.; HOFMANN, K.; BAIROCH, A. The PROSITE database, its status in 2002. Nucleic Acids Research, v.30, p.235-238, 2002.

FELDGARDEN, M.; RILEY, M. High levels of colicin resistance in Escherchia coli. Evolution, v.52. p.1270-1276, 1998.

FOLDES, T.; BANHEGYI, I.; HERPAI, Z.; VARGA, L.; SZIGETI, J. Isolation of bacillus strains from rhizosphere of cereals and in vitro screening for antagonism against phytopathogenic, food-born pathogenic and spoilage microorganisms. Journal of Applied Microbiology, v.89, p.840-846, 2000.

FRY, S. M.; MILHOLLAND, R. D. Multiplication and translocation of Xylella fastidiosa in petioles and stems of grapevine resistant, tolerant and susceptible to Pierce's disease. Phytopathology, v.80, p.61-65, 1990.

FUNDECITRUS - FUNDO DE PAULISTA DE DEFESA DA CITRICULTURA. Relatório de Gestão. Araraquara: Fundecitrus, 2002. Iv. (Relatório de Gestão 1995-2002). 
FUNKE, G.; ARAVENA-ROMAN, M.; FRODL, R. First description of Curtobacterium spp. isolated from human clinical specimens Journal of Clinical Microbiology, v. 43, p.1032-1036, 2005.

GARDNER, J. M.; FELDMAN, A. W.; ZABLOTOWICZ, M. Identity and behavior of xylem-residing bacteria in rough lemon roots of Florida citrus trees. Applied and Environmental Microbiology, v. 43, p.1335-1342,1982.

GARRIT, G. M. (Ed) The High G+C Gram-positive bacteria. Bergey's Manual of Determinative Bacteriology 2.ed. New York: Springer Verlag, 2004, p. $575 p$.

GORDON, D.; ABAJIAN, C.; GREEN, P. CONSED: a graphical tool for sequence finishing. Genome Research, v. 8, p.195-202,1998.

GROSS, D. C.; VIDAVER, A. K. Indigenous plasmids from of phytopathogenic Corynebacterium species. Journal of General Microbiology, v.115, p.479489, 1979a.

GROSS, D. C.; VIDAVER, A. K. Vidaver. Bacteriocins of phytopathogenic Corynebacterium species. Canadian Journal of Microbiology, v.25, p.367374, $1979 b$.

GROSS, D. C.; VIDAVER, A. K. Bacteriocins. In: KLEMENT, Z.; RUDOLPH, K.; SANDS, D. C. (Ed.), Methods in Phytobacteriology, Budapeste: Akademiai Kiado, 1990, p. 245-249. 
GUO, J. H.; CHEN, Y. F.; GUO, Y. H.; ZHANG, X.M.; GE, Y. Y. Curtobacterium flaccumfaciens pv. basellae pv. nov., a new pathovar of pathogen on malabar spinach. Não publicado, Submetido (04 -10-2003) Seqüência de

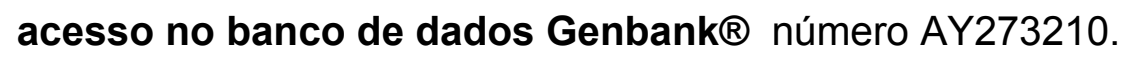

HALL, T. A. BioEdit : a user friendly biological sequence alignment editor and analysis program for Windows 95/98/NT. Nucleic Acids Symposim Series, v.41, p.95-98, 1999.

HALLMANN, J.; QUART-HALLMANN, A.; MAHAFFEE, W. F.; KLOEPPER, J. W. Bacterial endophytes in agricultural crops. Canadian Journal Microbiology, v. 43, p. 895-914, 1997.

HÉCHARD, Y.; SAHL, H. G. Mode of action of modified and unmodified bacteriocins from Gram-positive bacteria. Biochimie, v.84, p.545-557, 2002.

HEU, S.; OH, J.; KANG, Y.; RYU, S.; CHO, S. K.; CHO, Y. S.; CHO, M. gly gene cloning and expression and purification of glycinecin $A$, bacteriocin produced by Xanthomonas campestris pv. glycines 8ra. Applied and Environmental Microbiology, v. 67, p.4105-4110, 2001.

HILL, J. E.; PENNY, S. L.; CROWELL, K. G.; GOH, S. H.; HEMMINGSEN, S. M. cpnDB: A chaperonin sequence database. Genome Research, v.14, p.1669-1675, 2004.

HOITINK, H. A. J.; BOEHM, M. J. Biocontrol within the context of soil microbial communities: a substrate-dependent phenomenon. Annual Review of Phytopathology, v.37, p.427-446, 1999. 
HOPKINS, D. L.; PURCELL, A. H. Xylella fastidiosa: cause of Pierce's disease of grapevine and other emergent diseases. Plant Disease, v.86, p.10561066, 2002.

$\mathrm{HU}, \mathrm{H}$. Biochemical and genetic characterization of polymiyxin M produced by Paenibacillus kobensis M. Geneva 2003. 108p. Thesis (Ph.D) - Cornell University.

JABRANE, A.; SABRI, A.; COMPĖRE, P.; JACQUES, P.; VANDENBERGHE, I.; VAN BEEUMEN, J.; THONART, P. Characterization of serracin $p$, a phagetail-like bacteriocin, and its activity against Erwinia amylovora, the fire blight pathogen Applied and Environmental Microbiology, v.68, p.5704-5710, 2002.

JACK, R. W.; TAGG, J. R.; RAY, B. Bacteriocins of gram-positive bacteria. Journal of Microbiological Reviews, v.59, p.171-200, 1995.

JACK, R.; JUNG, G. Lantibiotics and microcins: polypeptides with unusual chemical diversity. Current Opinion in Chemical Biology, v.4, p.310-317, 2000.

JACOBS, J. L.; SUNDIN, G. W. Effect of solar UV-B radiation an a phyllosphere bacterial community. Applied and Environmental Microbiology, v.67, p.5488-5496, 2001.

JAMES, R.; LAZDUNSKI, C.; PATTUS, F. (Ed.) Bacteriocins, Microcins and Lantibiotics, New York: Springer, 1991, 519p.

JMP. Statistical Software for Macintosh, JMP version 3.1.5. Cary, NC. SAS Institute Inc. 1995. 
KIDO, Y.; HAMAKADO, T.; YOSHIDA, T.; ANNO, M.; MOTOKI, Y.; WAKAMIYA, T.; SHIBA, T. Isolation and characterization of ancovenin, a new inhibitor of angiotensin I converting enzyme, produced by actinomycetes. Journal of Antibiotics, v.36, p.1295-1299, 1983.

KIM, Y. M.; LIM, H. K.; CHO, S. K.; KIM, Y. W.; HYUN, J.; LEE, B. H.; KIM, B. J.; RIU, K. Z.; LEE, W. J.; CHO, M. Cloning of the Xanthomonas campestris pv glycines 8ra gene for glycinecin A secretion. World Journal of Microbiology and Biotechnology, v.20, p.99-103, 2004.

KIKUMOTO, T. Ecology and biocontrol of soft rot of chinese cabbage. Journal of General Plant Pathology, v.66, p.275-277, 2000.

KLAENHAMMER, T. R. Bacteriocins of lactic acid bacteria. Biochimie, v.70, p.337-349, 1988.

KLAENHAMMER, T. R. Genetics of bacteriocins produced by lactic acid bacteria. FEMS Microbiology Reviews, v.12, p.39-85, 1993.

KONEVA, N. D.; KRUGLOV, I. U. V. Dynamic of the volume and structure of the soil bacterial complex in the presence of azobenzene. Mikrobiologiia, v.70, p.552-557, 2001.

KRECHEL, A.; DITZ, M.; FAUPEL, A.; HALLMANN, J.; ULRICH, A.; BERG, G. Diversity and antagonistic potential towards plant pathogenic fungi of potatoassociated bacterial communities depends on microenvironments. Não publicado, 2003. Seqüência de acesso no banco de dados Genbank® número AJ581989. 
KYEREMEH, A. G.; KIKUMOTO, T.; CHUANG, D. Y.; GUNJI, Y.; TAKAHARA, $Y$. Isolation and evaluation of copper- and bactericide- resistant mutants of putative biocontrol agents of soft rot of chinese cabbage. Annals of Phytopathological Society of Japan, v.65, p.171-176, 1999.

LA DUC, M. T.; NICHOLSON, W.; KERN, R.; VENKATESWARAN, K. Microbial characterization of the Mars Odyssey spacecraft and its encapsulation facility. Environmental Microbiology, v.5, p.977-985, 2003.

LACAVA, P. T.; ARAÚJO, W. L.; MARCON, J.; MACCHERONI JUNIOR, W.; AZEVEDO, J. L. Interaction between endophytic bacteria from citrus plants and the phytopathogenic bacteria Xylella fastidiosa, causal agent of citrus variegated chlorosis. Letters in Applied Microbiology, v.39 p.55-59,2004.

LAGACÉ, L.; PITRE, M.; JACQUES, M.; ROY, D. Identification of the bacterial community of maple sap by using amplified ribosomal DNA (rDNA) restriction analysis and rDNA sequencing. Applied and Environmental Microbiology, v.70, p.2052-2056, 2004.

LARANJEIRA, F. F.; POMPEU JUNIOR, J.; HARAKAVA, R.; FIGUEIREDO, J. O.; CARVALHO, S. A.; COLLETA FILHO, H. D. Cultivares e espécies cítrica hospedeiras de Xylella fastidiosa em condições de campo. Fitopatologia Brasileira, v.23, p.147-154,1998.

LAVERMICOCCA, P.; LONIGRO, S. L.; VALERIO, F.; EVIDENTE, A.; VISCONTI, A. Reduction of olive knot disease by a bacteriocin from Pseudomonas syringae pv. ciccaronei. Applied and Environmental Microbiology, v.68, p.1403-1407, 2002. 
LEDNICKA, D.; MERGAERT, J.; CNOCKAERT, M. C.; SWINGS, J. Isolation and identification of cellulolytic bacteria involved in the degradation of natural cellulosic fibres. Systematic and Applied Microbiology, v.23, p.292-299, 2000.

LEE, R. F.; KERRICK, K. S.; BERETTA, M. J. G.; CHAGAS, C. M.; ROSSETTI, V. Citrus variegated chlorosis: a new destructive disease of citrus in Brazil. Citrus Industry, v.72, p.12-15,1991.

LEGARD, D. E.; MCQUILKEN, M. P.; WHIPPS, J. M.; FENLON, J. S.; FERMOR, T. R.; THOMPSON, I. P.; BAILEY, M. J.; LYNCH, J. M. Studies of seasonal changes in the microbial populations on the phyllosphere of spring wheat as a prelude to the release of a genetically modified microorganism. Agriculture Ecosystems and Environment, v.50, p.87101, 1994.

LEITE, R. M. V. B. C.; LEITE JUNIOR, R. P.; CERESINI, P. C. Hospedeiros alternativos de Xylella fastidiosa entre plantas invasoras de pomares de ameixeira com escaldadura da folha. Fitopatologia Brasileira, v.22, p.5457, 2002.

LIZUKA, H.; KOMAGATA, K. Microbiological studies on petroleum and natural gas. III:Determination of Brevibacterium, Arthrobacter, Micrococcus, Sarcina, Alcaligenes and Achromobacter isolated from oil-brines in Japan. Journal of General and Applied Microbiology, v.11, p.1-14, 1965.

LODEWYCKX, C.; VANGRONSVELD, J.; PORTEOUS, F.; MOORE, E. R. B.; TAGHAVI, S.; MEZGEAY, M.; VAN DER LELIE, D. Endophytic bacteria and their potential applications. Critical Reviews in Plant Sciences, v.21, p.583-606, 2002. 
MALDONADO, A.; RUIZ-BARBA, J. L.; JIMENEZ-DIAZ, R. Production of plantaricin NC8 by Lactobaccilus plantarum NC8 is induced in the presence of different types of Gram-positive bacteria. Archives of Microbiology, v.181, p.8-16, 2004.

MARGURRAN, A. E. Ecological diversity and its measurements. Princeton: Princeton University Press, 1998, 179p.

MARINGONI, A. C.; KUROZAWA, C. Tipificação de isolados de Cutobacterium flaccumfaciens pv. flaccumfaciens por bacteriocina. Pesquisa Agropecuária Brasileira, v.37, p.1339-1345, 2002.

MARTIN, N. I.; HU, H.; MOAKE, M. M.; CHUREY, J. J.; WHITTAL, R.; WOROBO, R. W.; VEDERAS, J. C. Isolation, structural characterization, and properties of Mattacin (Polymyxin M), a cyclic peptide antibiotic produced by Paenibacillus kobensis M. The Journal of Biological Chemistry, v.278, p.13124-13132, 2003.

MCQUILKEN, K.; PURDY, J.; RAINEY, P. B.; WHIPPS, J. M. Quantitative and qualitative seasonal changes in the microbial community from the phyllosphere of sugar beet (Beta vulgaris). Plant and Soil, v.150, p.177$191,1993$.

MILLER, M. B.; BASSLER, B. L. Quorum sensing in bacteria. Annual Review of Microbiology, v.55, p.165-199, 2001.

MOCALI S.; BERTELLI, E.; DI CELLO, F. P.; MENGONI, A.; SFALANGA, A.; VILIANI, F. A.; CACIOTTI A.; TEGLI, S.; SURICO, G.; FANI, R. Fluctuation of bacteria isolated from elm tissues during different seasonsand from different plant organs. Research in Microbiology, v.154, p.105-114, 2003. 
MOREIRA, L. M.; DE SOUZA; R. F. DIGIAMPIETRI, L. A.; DA SILVA, A. C. R., SETUBAL, J. C. Comparative analyses of Xanthomonas and Xylella complete genomes. OMICS-A Journal of Integrative Biology, v.9, p.43-76, 2005.

MUNIF, A.; HALLMANN, J.; SIKORA, R. A. Induced systemic resistance of selected endophytic bacteria against Meloidogyne incognita on tomato. Meded Rijksuniv Gent Fak Landbouwkd Toegep Biol Wet, v.66, p.663669, 2001.

NEJAD, P.; JOHNSON, P. A. Endophytic bacteria induce growth promotion and wilt disease suppression in oilseed rape and tomato. Biological Control, v.18, p. 208-215, 2000.

NILSEN, T.; NES, I. F.; HOLO, H. An exported inducer peptide regulates bacteriocin production in Enterococcus faecium CTC492. Journal of Bacteriology, v.180, p.1848-1854,1998.

NUNES, L.R.; ROSATO, Y.B.; MUTO, N.H.; YANAI, G.M.; DA SILVA, V.S.; LEITE, D.B.; GONÇALVES, E.R.; DE SOUZA, A.A.; COLETTA-FILHO, H.D.; MACHADO, M.A.; LOPES, S.A.; DE OLIVEIRA, R.C. Microarray analyses of Xylella fastidiosa provide evidence of coordinated transcription control of laterally transferred elements. Genome Research, v.13, p.570578, 2003.

OGUNBANWO, S. T.;SANNI, A. I.; ONILUDE, A. A. Infuence of bacteriocin in the control of Escherichia coli infection of broiler chickens in Nigeria. World Journal of Microbiology and Biotechnology, v.20, p.51-56, 2004. 
OSCARIZ, J. C.; PISABARRO, A. G. Classification and mode of action of membrane-active bacteriocins produced by gram-positive bacteria. International Microbiology, v.4, p.13-19, 2001.

OWEN, N. L.; HUNDLEY, N. Endophytes - The chemical synthesizers inside plants. Science Progress, v.87, p.79-89, 2004.

PAETZEL, M.; DALBEY, R. E.; STRYNADKA, N.C. The structure and mechanism of bacterial type I signal peptidases a novel antibiotic target. Pharmacology and Therapheutics, v.87, p.27-49, 2000.

PASHALIDIS, S.; MOREIRA, L. M; ZAINI, P. A; CAMPANHARO, J. C.; ALVES, L. M. C.; CIAPINA, L. P.; VÊNCIO, R. Z .N.; LEMOS E. G. M.; DA SILVA, A. M.; DA SILVA, A. C. R. Whole-genome expression profiling of Xylella fastidiosa in response to growth on glucose. OMICS - A Journal of Integrative Biology, v. 9, p.77-90, 2005.

PARRA, J. R. P.; OLIVEIRA, H. N.; PINTO, A. S. Guia ilustrado de pragas e insetos benéficos dos citros. Piracicaba : Imprenta, 2003, 140 p.

PARRET, A. H. A.; DE MOT, R. Bacteria killing their own kind: novel bacteriocins of Pseudomonas and other gamma-proteobacteria. Trends in Microbiology, v.10, p.107-112, 2002.

PARRET, A. H. A.; SCHOOFS, G.; PROOST, P.; DE MOT, R. Plant lectin-like bacteriocin from rhizosphere-colonizing Pseudomonas isolate. Journal of Bacteriology, v.185, p.897-908, 2003. 
PHAM, H. T.; RIU, K. Z.; JANG, K. M.; CHO, S. K.; CHO, M. Bactericidal activity of glycinecin A, a bacteriocin derived from Xanthomonas campesteris pv. glycines on phytopathogenic $X$. campesteris pv. vesicatoria cells. Applied and Environmental Microbiology, v.70, p.4486-4490, 2004.

PINÕN, D., CASAS, M.; BLANCH, M.; FONTANIELLA, B.; BLANCO, Y.; VICENTE, C.; SOLAS, M. T.; LEGAZ, M. E. Gluconacetobacter diazotrophicus, a sugar cane endosymbiont, produces a bacteriocin against Xanthomonas albilineans, a sugar cane pathogen. Research in Microbiology, v.153, p.345-351, 2002.

PUGSLEY, A. P.; OUDEGA, B. Methods of studying colicins and their plasmids. In: HARDY, K. G. (Ed.) Plasmids, a practical approach, Oxford: IRL Press-Oxford University Press, 1987, p.105-161.

RHODES, A. N.; URBANCE, J. W.; YOUGA, H.; CORLEM-NEWMAN, H.; REDDY, C. A.; KLUG, M. J.; TIEDJE, J. M.; FISHER, D. C. Identification of bacterial isolates from intestinal contents associated with 12,000-year-old mastodon remain. Applied and Environmental Microbiology, v.64, p.651658, 1998.

RICHERT, K.; BRAMBILLA, E.; STACKEBRANDT, E. Development of PCR primers specific for the amplification and direct sequencing of gyrB genes from Microbacteria, order Actinomycetales. Não publicado Submetido (0102-2005) Seqüência de acesso no banco de dados Genbank ${ }^{\circledR}$ número AJ784795.

RILEY, M. A.; WERTZ, J. E. Bacteriocins: evolution, ecology, and application. Annual Review of Microbiology, v.56, p.117-137, 2002. 
ROSSETI, V.; GARNIER, M.; BOVÉ, J. M.; BERETTA, M. J. G.; TEIXEIRA, A. R.; QUAGGIO, J. A.; DE NEGRI, J. D. Présence des bactéries dans le xyléme dóranges atteints de chlorose variégée, une nouvelle maladie des agrumes au Brésil. Comptes Rendus de l'Academie des Science des Paris, v.310, p.345-349, 1990.

ROSSETI; V.; DE NEGRI, J. D. Clorose Variegada dos Citros: Revisão. Laranja, v.11, p.1-14, 1990.

ROGER, L.A. The inhibiting effect of Streptococcus lactis on Lactobacillus bulgaricus. Journal of Bacteriology, v.16, p.321-325, 1928.

SAHL, E.; BIERBAUM, G. Lantibiotics: Biosynthesis and biological activities of uniquely modified peptides from Gram-positive bactéria, Annual Review of Microbiology, v.52 p.41-79, 1998.

SAMBROOK, J.; RUSSEL, D. W. Molecular Cloning: a laboratory manual, 3.ed., New York: Cold Spring Harbor Laboratory Press, 2001, p.1.31-1.38.

SCHAGGER, H.; VON JAGOW, G. Tricine- Sodium Dodecyl Sulfatepolyacrylamide gel electrophoresis for the separation of proteins in the range from 1 to $100 \mathrm{kDa}$. Analytical Biochemistry, v.166, p.368-379, 1987.

SCHLEIFER, K. H. ; KANDLER, O. Peptidoglycan types of bacterial cell walls and their taxonomic implications. Bacteriological Reviews, v.36, p.407477,1972 . 
SEGHERS, D. ; WITTEBOLLE, L.; TOP, E. M.; VERSTRAET, W.; SICILIANO, S. D. Impact of agricultural practices on the Zea mays L. endophytic community. Applied and Environmental Microbiology, v.70, p.14751482, 2004.

SHODA, M. Bacterial control of plants disease. Journal of Bioscience and Bioengineering, v.89, p.515-521, 2000.

SHULTZ, H. A.; MATTHEWS, M. A.Resistance to water transport in shoots of Vitis vinifera L. Plant Physiology, v.88, p.718-724,1988.

SIMPSON, A. J. G.; REINACH, F. C.; ARRUDA, P.; MEIDANIS, J.; SETUBAL, J. C. et al. The genome sequence of the plant pathogen Xylella fastidiosa. Nature, v.406, p.151-159, 2000.

SKERMAN, V. B. D.; MCGOWAN, V.; SNEATH, P. H. A. Approved Lists of Bacterial Names. International Journal of Systematic Bacteriology, v.30, p.225-420, 1980.

SMITH, J. L.; FRATAMICO, P. M.; NOVAK, J. S. Quorum sensing: A primer for food microbiologists. Journal of Food Protection, v.67, p.1053-1070, 2004.

SMIDT, M. L.: VIDAVER, A. K. Isolation anda characterization of syringacin W1, a bacteriocin produced by Pseudomonas syringae pv. syringae. Canadian Journal of Microbiology, v.32, p.231-236, 1986.

SOUZA, A. A.; TAKITA, M. A.; PEREIRA, E. O.; COLETTA-FILHO, H.; MACHADO, M. A. Expression of pathogenicity-related genes of Xylella fastidiosa in vitro and in planta. Current Microbiology, v. 50, p. 223-228, 2005. 
SOUZA, L. A. Produção e caracterização de mutantes do operon gum de Xylella fastidiosa. Piracicaba 2002. 96p. Tese (Mestrado) - Escola Superior de Agricultura “Luiz de Queiroz”, Universidade de São Paulo.

STEAD, D. E. Identification of bacteria by computer assisted fatty acid profiling. Acta Horticulturae, v.225, p.39-46, 1988.

STROBEL, G.; DAISY, B. Bioprospecting for microbial endophytes and their natural products. Microbiology and Molecular Biology Reviews, v.67, p.491-502, 2003.

STROMPFOVÁ, V.; LAUROKOVA, A.; OUWEHAND, A. C. Lactobacilli and Enterococci - potential probiotic for dogs. Folia Microbiologica, v.49, p.203-207, 2004b.

STROMPFOVÁ, V.; LAUROKOVA, A.; OUWEHAND, A. C. Selection of enterococci- for potential canine probiotic additives. Veterinary Microbiology, v.100, p.107-114, 2004a.

TAN, R. X.; ZOU, W. X. Endophytes: a rich source of functional metabolites. Natural Products Reports, v.18, p.448-459, 2001.

THOMPSON, I. P.; BAILEY, M. J.; FENLON, J. S.; FERMOR, T. R.; LILEY, A. K.; LYNCH, J. M.; MCCORMACK, P. J.; TSAVKELOVA M. P.; CHERDYNTSEVA, E. A.; LOBAKOVA, T. A.; KOLOMEITSEVA, E. S.; NETRUSOV,A. I. Microbiota of the Orchid rhizoplane. Mikrobiologiia, v.70, p.567-573, 2001. 
THOMPSON, J. D.; HIGGINS, D. G.; GIBSON, T. J. CLUSTAL W: improving the sensitivity of progressive multiple sequence alignments through sequence weighting, position-specific gap penalties and weight matrix choice. Nucleic Acids Research, v. 22, p.4673-4680, 1994.

TUDOR-NELSON, S. M.; MINSAVAGE, G. V., STALL, R. E.; JONES, J. B. Bacteriocin-like substances from tomato race 3 strains of Xanthomonas campestris pv. Vesicatoria. Phytopathology, v.93, p.1415-1421, 2003.

TURNER, J. W.; JORDAN, H. V. Bacteriocin-like activity within the genus Actinomyces. Journal of Dentistry Research, v.60, p.1000-1007, 1981.

VIDAVER, A. K. The plant pathogenic corynebacteria. Annual Review of Microbiology,v.36, p. 495-517, 1982.

WANDERSMAN, C. Protein and peptide secretion by ABC exporters. Research in Microbiology, v.149, p.163-170, 1998.

WANG, H. M.; WANG, H. X.; NIG, T. B.; LI, J. Y. Purification and charcterization of an antibacterial compound produced by Agrobacterium vitis strain E26 with activity against $A$. tumefasciens. Plant Pathology, v.52, p.134-139, 2003.

XIE, L.; MILLER, L. M.; CHAMPAK, C.; AVERIN, O.; KELLEHER, N. L.; VAN DER DONK, W. A. Lacticin 481: In vitro reconstitution of lantibiotic synthetase activity. Science, v.303, p.679-681, 2004. 
YAMAMOTO, Y.; TOGAWA, Y.; SHIMOSAKA, M.; OKASAKI, M. Purification and characterization of a novel bacteriocin produced by Enterococcus faecalis strain RJ-11. Applied and Environmental Microbiology, v.69, p.5746-5753, 2003.

YOUNG, J. M.; WATSON, D. R. W.; DYE, D. W. Reconsideration of Arthrobacter ilicis (Mandel et al.1961) Collins et al. 1982 as a plantpathogenic species. Proposal to emend the authority and description of the species. Request for an opinion. International Journal of Systematic and Evolutionary Microbiology, v.54, p.303-305, 2004.

ZACZYNSKA, E.; BLACHOLSZEWSKA, Z.; FELDMANE, G.; DUKS, A.; MORDASKA, H.; BIZUNIAK, I.; CEMBRZYNSKANOWAK, M.; LUGOWSKI, C. Effect of natural and synthetic immunomodulators on the synthesis of interferon by peritoneal cell of mice. Acta Virologica, v.36, p.121-128, 1992.

ZINNIEL, D. K.; LAMBRECHT, P.; HARRIS, N. B.; FENG, Z.; KUCZMARSKI, D.; HIGLEY,P.; ISHIMARU, C.A. ARUNAKUMARI, A.; BARLETTA, R.G.; VIDAVER, A.K. Isolation and characterization of endophytic colonizing bacteria from agronomic crops and prairie plants. Applied and Environmental Microbiology, v.68, p.2198-2208, 2002.

ZUPAN, J. R.; ZAMBRYSKI, P. Transfer of T-DNA from Agrobacterium to the plant cell. Plant Physiology, v.107, p.1041-1047, 1995. 